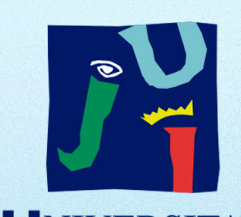

UNIVERSITAT

JAUME•I

\title{
Psychological Capital in Schools
}

Marcos Carmona Halty

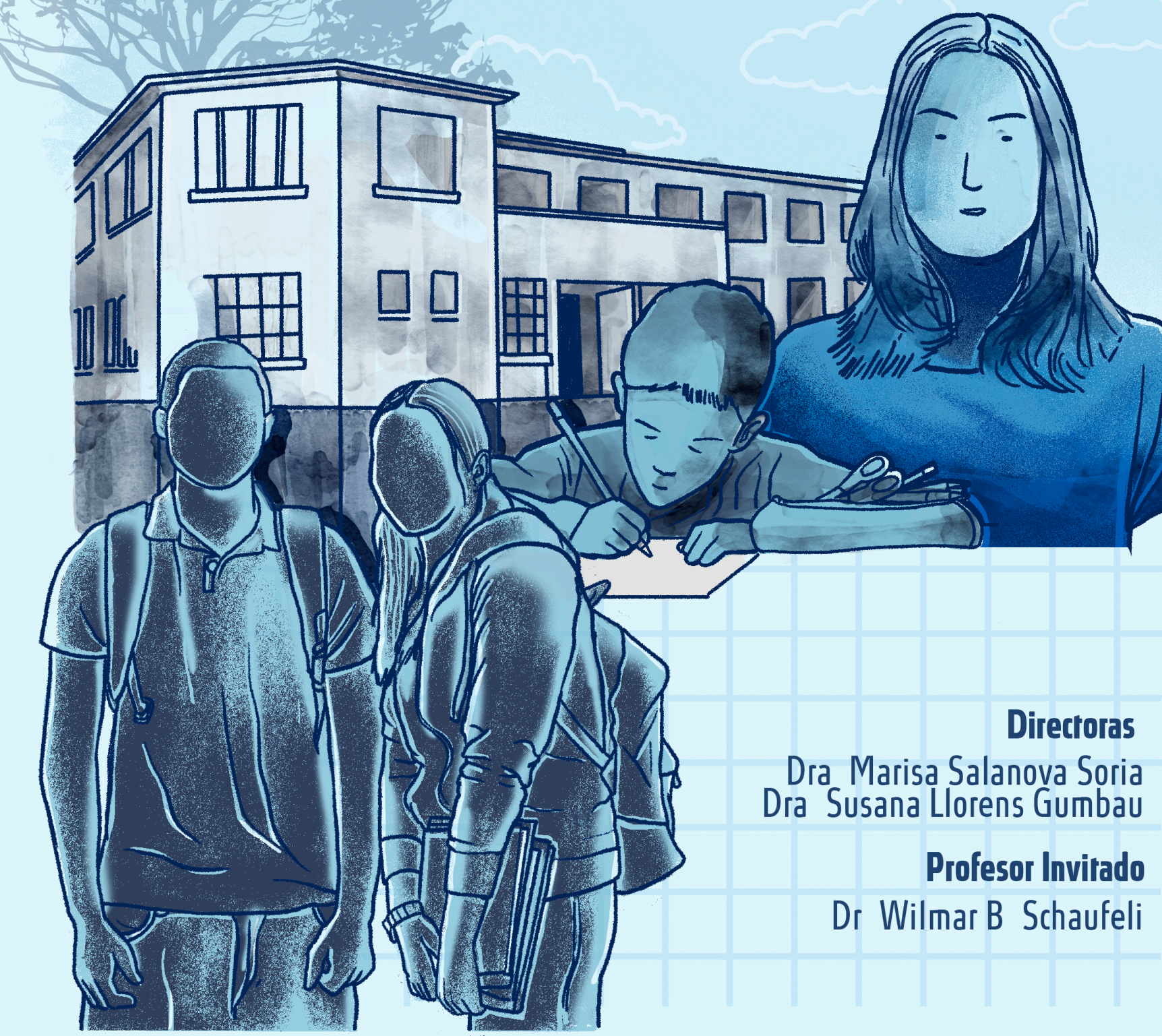




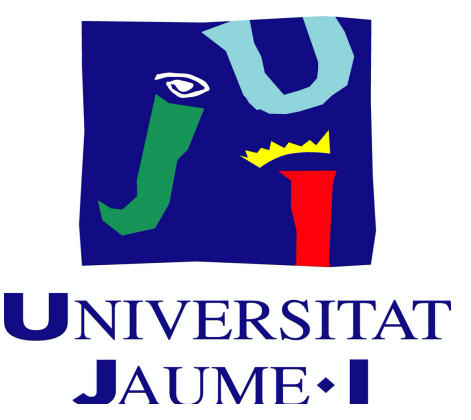

\section{Psychological Capital in Schools}

\section{Capital Psicológico en Escuelas}

Marcos Carmona Halty

Directoras:

Dra. Susana Llorens Gumbau

Dra. Marisa Salanova Soria

Profesor Invitado:

Dr. Wilmar B. Schaufeli 



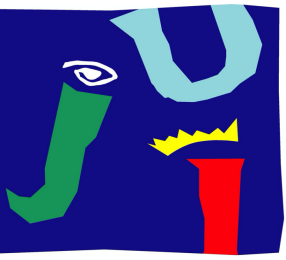

UNIVERSITAT

JAIJME•

\title{
Programa de Doctorado en Psicología
}

\section{Escuela de Doctorado de la Universitat Jaume I}

\author{
Psychological Capital in Schools \\ Capital Psicológico en Escuelas
}

Memoria presentada por Marcos Carmona Halty para optar al grado de doctor por la Universitat Jaume I

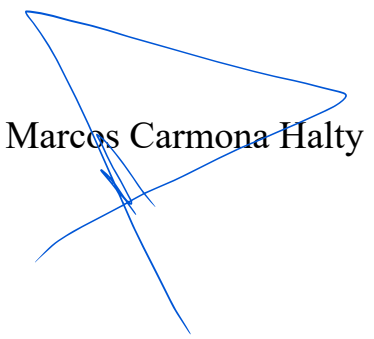

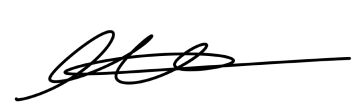

Dra. Marisa Salanova Soria

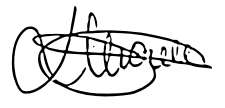

Dra. Susana Llorens Gumbau 


\section{Financiación recibida}

La realización de la presente tesis doctoral ha sido posible gracias a la financiación de:

Beca de Estudios de Doctorado en el Extranjero de la Comisión Nacional de Investigación Científica y Tecnológica (CONICYT) del Ministerio de Educación del Gobierno de Chile.

Beca de Estudios de Doctorado en el Extranjero de la Universidad de Tarapacá, Chile.

\section{(9) $(\Theta \odot$}

No está permitido el uso comercial de la obra original ni de las posibles obras derivadas. La distribución debe hacerse con una licencia igual a la que regula la obra original.

The commercial use of the original work or of possible derivative Works is not allowed. The distribution must be in the same terms as the original work. 


\section{AGRADECIMIENTOS:}

A las autoridades de la Universidad de Tarapacá por patrocinar mi estancia doctoral en la Universitat Jaume I. Al rector, Dr. Emilio Rodríguez Ponce, vicerrector académico, Dr. Alfonso Díaz Aguad, vicerrectora de desarrollo estratégico, Dra. Jenniffer Peralta Montecinos, vicerrector de administración y finanzas, Sr. Álvaro Palma Quiroz, y a la decana de la Facultad de Ciencias Sociales y Jurídicas, Dra. Marietta Ortega Perrier.

A la Dra. Marisa Salanova Soria y la Dra. Susana Llorens Gumbau, por invitarme al WANT, confiar en mis competencias, y permitir el desarrollo de este proyecto con la autonomía necesaria para llevarlo a buen puerto. Compartir con vosotras ha sido una experiencia muy enriquecedora y estimulante.

Al Dr. Wilmar B. Schaufeli, por su invaluable contribución a cada uno de los artículos que componen esta tesis. Trabajar con el profesor Wilmar ha sido un gran honor y una de las experiencias más desafiantes y gratificantes de mi carrera académica.

A mi madre, Rosa Halty Morgado, por su infinito amor e incansable labor para promover mi desarrollo profesional, y a Paulina Rojas Paz, por formar parte central de mi vida, apoyar mis proyectos, y compartir innumerables momentos de alegría y felicidad.

A Rodrigo Ferrer Urbina y Soi-yan Lay Aqueveque, por sus constantes demostraciones de afecto, y a Sergio y Patricio Cabrera Uribe por considerarme uno más dentro de su familia. A mis amigos de infancia, del colegio y la universidad, por sus diversas expresiones de afecto y cariño a lo largo de estos años.

A quienes hicieron más agradables los días en Castellón y Valencia, Vicent Soler y Eva Jiménez, Teresa Murillo y Elia Escoliano, a los profesores de la Escuela de Arte Gaia, amigos del Bar Gran Canaria y la Malvarrosa, y a todos con quienes tuve la oportunidad de compartir.

A mis profesores de la Universidad de Tarapacá, por inspirar mi interés por el quehacer académico. Agradezco con especial afecto a Sergio Pulido Roccatagliata y María Alburquenque Eliash, por formar parte de mi red de apoyo afectivo en diversos momentos adversos.

A los establecimientos educativos que se interesaron en el proyecto, a los más de 2000 estudiantes que participaron en él, a los colegas, profesores y estudiantes de pregrado que apoyaron su adecuada ejecución; y a la comunidad Grupo BPPF y al proyecto Sci-Hub por la gran labor que realizan en contra de las ganancias injustas que las editoras obtienen al crear límites a la distribución del conocimiento.

Sin la ayuda, apoyo y cariño de todos vosotros esta tesis no hubiese sido posible. 
Tesis por compendio de publicaciones:

Thesis by compendium of publications:

Carmona-Halty, M., Salanova, M., Llorens, S., \& Schaufeli, W. B. (2019). How psychological capital mediates between study-related positive emotions and academic performance. Journal of Happiness Studies, 20(2), 605-617. https://doi.org.10.1007/s10902-018-9963-5

Journal of Happiness Studies; JCR (2019): 2.344 (Rank 20/108: Q1); Category: SOCIAL SCIENCES, INTERDISCIPLINARY

Carmona-Halty, M., Salanova, M., Llorens, S., \& Schaufeli, W. B. (2019). Linking positive emotions and academic performance: The mediated role of academic psychological capital and academic engagement. Current Psychology. https://doi.org.10.1007/s12144-019-00227-8

Current Psychology; JCR (2019): 2.051 (Rank 46/138: Q2); Category: PSYCHOLOGY, MULTIDISCIPLINARY

Carmona-Halty, M., Schaufeli, W. B., \& Salanova, M., \& (2019). Good relationships, good performance: The mediated role of psychological capital - A three-wave study among students. Frontiers in Psychology, 10: 306.

https://doi.org.10.3389/fpsyg.2019.00306

Frontiers in Psychology; JCR (2019): 2.067 (Rank 45/138: Q2); Categories: PSYCHOLOGY, MULTIDISCIPLINARY

Carmona-Halty, M., Salanova, M., \& Schaufeli, W. B. (2020). The strengthening starts at home: Parent-child relationships, psychological capital, and academic performance - A longitudinal mediation analysis. Current Psychology. https://doi.org.10.1007/s12144-020-00898-8

Current Psychology; JCR (2019): 2.051 (Rank 46/138: Q2); Category: PSYCHOLOGY, MULTIDISCIPLINARY.

Carmona-Halty, M., Schaufeli, W. B., Llorens, S., \& Salanova, M. (2019). Satisfaction of basic psychological needs leads to better academic performance via increased psychological capital: A three-wave longitudinal study among high school students. Frontiers in Psychology, 10: 2113. https://doi.org.10.3389/fpsyg.2019.02113

Frontiers in Psychology; JCR (2019): 2.067 (Rank 45/138: Q2); Categories: PSYCHOLOGY, MULTIDISCIPLINARY

Esta tesis dispone de la aceptación de los coautores de las publicaciones que el doctorando presenta como tesis y su renuncia expresa a presentarlas como parte de otra tesis doctoral.

This thesis has been accepted by the co-authors of the publications listed above that have rejected present them as a part of another $\mathrm{PhD}$ thesis. 



\section{Psychological Capital in Schools}

\begin{tabular}{|c|c|c|}
\hline & Contents & Page \\
\hline Chapter 1 & Introducción General & 9 \\
\hline Chapter 2 & $\begin{array}{c}\text { How Psychological Capital Mediates Between Study-related } \\
\text { Positive Emotions and Academic Performance }\end{array}$ & 23 \\
\hline Chapter 3 & $\begin{array}{c}\text { Linking Positive Emotions and Academic Performance: The } \\
\text { Mediated Role of Academic Psychological Capital and Academic } \\
\text { Engagement }\end{array}$ & 45 \\
\hline Chapter 4 & $\begin{array}{l}\text { Good Relationships, Good Performance: The Mediated Role of } \\
\text { Psychological Capital - A Three-wave Study Among Students }\end{array}$ & 69 \\
\hline Chapter 5 & $\begin{array}{c}\text { The Strengthening Starts at Home: Parent-child Relationships, } \\
\text { Psychological Capital, and Academic Performance - A Longitudinal } \\
\text { Mediation Analysis }\end{array}$ & 81 \\
\hline Chapter 6 & $\begin{array}{c}\text { Satisfaction of Basic Psychological Needs Leads to Better Academic } \\
\text { Performance Via Increased Psychological Capital: A Three-wave } \\
\text { Longitudinal Study Among High School Students }\end{array}$ & 102 \\
\hline Chapter 7 & Conclusión General & 117 \\
\hline
\end{tabular}





\section{Chapter 1 \\ Introducción General}

El incremento de los índices de depresión en población infantil y adolescente, el escaso aumento de sus niveles de satisfacción con la vida, y la sinergia entre aprendizaje y emociones, justifica la enseñanza de habilidades relativas al bienestar en ambientes escolares (Seligman et al., 2009). En esta dirección, la escuela es uno de los contextos de desarrollo más importante en la vida de niños, niñas y adolescentes, y es una fuente clave en el aprendizaje de destrezas vinculadas a una adecuada adaptación al entorno (Hamilton y Hamilton, 2009). Además, la escuela suele ser un lugar asequible, familiar, y estable, que facilita la implementación de iniciativas orientadas a la promoción de la salud, y, por tanto, se encuentra en una posición privilegiada para promover el desarrollo óptimo de los estudiantes y de todos quienes participan en ella (Bond et al., 2007).

La Educación Positiva (EP) es un área emergente de estudio orientada a favorecer -sin ignorar aquellos aspectos negativos inherentes a toda actividad humana- que los miembros de la comunidad educativa florezcan $-\mathrm{o}$ en palabras de Abraham Maslow-, se autoactualicen y desarrollen al máximo su potencial (Jacobs y Renandya, 2019). Más específicamente, la EP es una disciplina que surge a partir de la Psicología Positiva (PP) -orientada al estudio científico de las características individuales, relaciones interpersonales e instituciones que contribuyen a la felicidad de las personas (Seligman y Csikszentmihalyi, 2000)- y tiene por objetivo complementar el tradicional énfasis otorgado al desarrollo de destrezas académicas, con iniciativas de fomento del bienestar y funcionamiento óptimo de los estudiantes (Norrish et al., 2013; Seligman et al., 2009; Shoshani y Slone, 2017; Shoshani y Steinmetz, 2013).

La investigación reciente - enmarcada dentro de la EP- ha demostrado que el cultivo de las fortalezas y recursos personales, son vías potenciales para incrementar el desempeño y otros resultados deseables asociados al ámbito escolar (Datu et al., 2019; Steinmayr et al., 2018; Widlund et al., 2018; Zhang y Chen, 2018). Además, se ha constatado la eficacia de programas orientados al incremento de los niveles de bienestar y disminución de sintomatología depresiva, 
que favorecen un mejor desempeño académico (Carbonero et al., 2017; Schoeps et al., 2018; Shoshani y Slone, 2017; Shoshani y Steinmetz, 2013). A pesar del innegable aporte que la literatura reciente ofrece a los objetivos de la EP, cuando surgen nuevos constructos en áreas emergentes del conocimiento (como la EP), el trabajo de los investigadores es explorar las eventuales asociaciones entre la nueva información disponible y el conocimiento previamente establecido. En esta dirección, la presente tesis se configura como una aportación a la EP que centra su atención en un constructo relativamente reciente -originado en la PP en general, y en el Comportamiento Organizacional Positivo (COP), en particular- y que ha sido escasamente examinado en contextos escolares: el capital psicológico (CP).

El CP es un estado psicológico positivo caracterizado por la presencia simultánea de: 1) confianza para asumir tareas retadoras y realizar el esfuerzo necesario para obtener éxito en ellas (autoeficacia); 2) atribuciones positivas relativas a experiencias de éxito pasado, actual y futuro (optimismo); 3) perseverancia en el cumplimiento de los objetivos asumidos y de ser necesario redirección de las vías que conducen a la finalización exitosa de dichos objetivos (esperanza); y 4) mantenimiento y recuperación en circunstancias adversas y/o problemáticas (resiliencia) con la finalidad de obtener éxito en las tareas asumidas (adaptado de Luthans et al., 2007). A pesar de que los recursos personales que componen el $\mathrm{CP}$ han demostrado -individualmente- ser relevantes en la predicción de diversos resultados positivos tanto en contextos laborales (p.e., Bakker y Demerouti, 2007; Ouweneel et al., 2012; Xanthopoulou et al., 2009) como académicos (p.e., Gallagher et al., 2016; Ouweneel et al., 2011; Snyder et al., 2002), la noción de simultaneidad del constructo CP marca una diferencia ya que -en conjunto- sus componentes actuarían sinérgicamente, otorgando un efecto superior al que se conseguiría con la suma de sus efectos individuales (Luthans et al., 2007). De esta manera, no es posible asumir que el conocimiento relativo a los recursos que componen el CP permite obviar la investigación en torno a este como un constructo de segundo orden (Datu et al., 2016).

Aunque relacionados, el CP va más allá de las tradicionales nociones de capital humano -el conocimiento, habilidades y capacidades que pueden incrementarse mediante la experiencia y/o la inversión en educación y capacitación individual (Bekker, 1993)- y capital social -los 
recursos reales o potenciales vinculados a la posesión de una red duradera de relaciones (Newman et al., 2014). Esto es, mientras el capital humano y el capital social se refieren a "lo que sabes" y a "quien conoces" respectivamente, el CP se refiere a "quién eres" y a "quién puedes (llegar a) ser", introduciendo la noción de cambio desde un estado psicológico actual a un estado psicológico futuro (Avolio y Luthans, 2006). De esta manera, el CP ofrece un marco conceptual de orden superior que facilita la comprensión y capitalización de un conjunto de recursos psicológicos -autoeficacia, optimismo, esperanza y resiliencia- presentes (en mayor o menor medida) en todas las personas; que han demostrado relevancia en diversas áreas del desempeño humano, y son factibles de ser incluidos en el repertorio conductual de las personas a través de una intervención deliberada denominada Psychological Capital Intervention (Luthans y YoussefMorgan, 2004).

La investigación previa ha demostrado que el CP se relaciona directamente con resultados laborales deseables -tales como un buen desempeño, y mayores niveles de satisfacción y compromiso- e inversamente con resultados laborales indeseables -tales como mayores niveles de burnout, intención de abandono y estrés- (Avey et al., 2011; Newman et al., 2014). Estos resultados son coherentes con la teoría conservation of resources (COR; Hobfoll, 1989) que explica el estrés y la motivación humana a partir de la interacción entre factores internos y ambientales (Hobfoll, 2002; 2011). En breve, esta teoría señala que las personas intentan acumular tantos recursos -biológicos, sociales, o individuales-como les sea posible ya que dicha acumulación posibilita la adquisición de nuevos recursos, generando espirales de ganancia (en forma de caravana de recursos) que contribuyen a su bienestar. Sin embargo, en algunas circunstancias, las personas pueden ver amenazados e inclusive mermados sus niveles de recursos, generando espirales de pérdida que contribuyen a su malestar (Demerouti et al., 2004; Salanova et al., 2010). En otras palabras, las personas estarán motivadas a invertir sus recursos p.e., tiempo, esfuerzo o dedicación- en aquellas tareas que faciliten la obtención de nuevos recursos - p.e., autoeficacia-, los cuales favorecerán un adecuado afrontamiento a nuevos desafíos que, finalmente, incrementarán sus niveles de bienestar. Por otra parte, en circunstancias en que algunos factores ambientales influyan en la pérdida y disminución de los recursos de las personas 
-p.e., debido a una sobrecarga de trabajo- disminuirá también la capacidad de ellas para afrontar adecuadamente nuevos desafíos -p.e., desarrollar nuevas habilidades-, lo cual, finalmente, incrementará sus niveles de malestar. De esta manera, el CP puede ser comprendido como una caravana de recursos -formada por autoeficacia, optimismo, esperanza, y resiliencia- originada en la motivación de las personas por acumular recursos psicológicos, los cuales -ha demostrado la investigación- favorecen la resolución exitosa de determinados desafíos, situando a las personas en una posición privilegiada para afrontar nuevas demandas y retos, con el resultado de un incremento en sus niveles de bienestar.

Si bien el CP fue propuesto como un constructo relativo al contexto laboral-industrial, en años recientes, la noción de CP académico ha comenzado a surgir en contextos de educación (p.e., Datu et al., 2016; Datu y Valdez, 2016; Luthans et al., 2012; Siu et al., 2014). La razón para considerar al CP -y otros conceptos tales como burnout y engagement- un constructo aplicable en ámbitos educativos es que -psicológicamente hablando- las actividades que realizan estudiantes y trabajadores poseen similitudes relativas al desarrollo de actividades estructuradas y direccionadas a objetivos de naturaleza obligatoria (Schaufeli et al., 2002). Es decir, las instituciones de educación son lugares en donde los estudiantes "trabajan" asistiendo a clases y/o llevando a cabo tareas, proyectos y actividades por las cuales son evaluados y reconocidos por sus pares y/o evaluadores (Salmela-Aro y Upadyaya, 2012). Adicionalmente, existe evidencia que indica que las características que influyen en el éxito académico de los estudiantes no difieren significativamente de las características que influyen en el éxito laboral de los trabajadores (Datu y Valdez, 2016; Siu et al., 2014).

Si aceptamos el razonamiento anterior, podemos asumir que el CP académico describe a aquellos estudiantes que simultáneamente: 1) poseen confianza al asumir tareas académicas retadoras y se esfuerzan para obtener éxito en ellas (son eficaces); 2) hacen atribuciones positivas relativas a experiencias de éxito académico actual y futuro (son optimistas); 3) perseveran en el cumplimiento de los objetivos académicos asumidos y son capaces de redireccionar las vías que conducen a la finalización exitosa de dichos objetivos (poseen esperanza); y 4) se mantienen y recuperan en circunstancias académicas adversas y/o problemáticas (son resilientes) con la 
finalidad de obtener éxito en las tareas académicas propuestas (adaptado de Luthans et al., 2007). La definición de $\mathrm{CP}$ académico mantiene íntegramente los elementos que constituyen la definición de CP tradicional; además, se adapta a las condiciones académicas generales de los estudiantes, y posibilita su incorporación -como un constructo que puede ser de utilidad- a los objetivos de la EP, es decir, a examinar los procesos subyacentes al florecimiento o funcionamiento óptimo de los estudiantes en contextos académicos.

Una vez asumido el desafío de investigar en torno al $\mathrm{CP}$ académico, la presente tesis comenzó con una revisión exhaustiva de la literatura científica relativa a este constructo, para lo cual se introdujeron palabras clave tales como psychological capital, positive psychological capital, y PsyCap en las principales bases de datos electrónicas científicas (i.e., PsycINFO, SCOPUS, Web of Science, y Taylor and Francis). Los resultados de esta revisión permitieron constatar que:

1) La investigación relativa al CP académico se ha llevado a cabo tradicionalmente en contextos de educación superior, con escasa atención en contextos escolares (p.e., Martínez et al., 2019; Ortega-Maldonado y Salanova, 2018; Siu et al., 2014).

2) La investigación relativa al CP académico se ha enfocado principalmente en examinar su influencia en diferentes resultados académicos, con escasa atención a sus posibles antecedentes (p.e., Datu, King, y Valdez, 2016; Datu y Valdez, 2019; Luthans et al., 2012).

3) La investigación en torno al $\mathrm{CP}$ académico ha utilizado principalmente medidas de autoinforme y diseños de investigación de tipo transversal, con escasa incorporación de medidas externas y diseños de tipo longitudinal (p.e., Datu y Valdez, 2016; Datu y Valdez, 2019; You, 2016).

En base a los antecedentes presentados, el objetivo de la presente tesis fue examinar la aplicabilidad del CP académico en un contexto escolar ${ }^{1}$, aportando evidencia empírica sobre sus antecedentes y resultados académicos. Para ello, se elaboró un modelo (ver Figura 1) que incluye tres categorías de antecedentes, en coherencia con los ejes tradicionales de estudio de la PP (i.e., características individuales, relaciones interpersonales, e instituciones que promueven el bienestar y felicidad de las personas) y dos resultados académicos, en coherencia con los objetivos de la 
EP (i.e., bienestar y desempeño académico). Adicionalmente, en línea con los vacíos encontrados en la revisión teórica, los estudios que sustentan el modelo propuesto incluyen medidas basadas en autoinformes y fuentes externas, así como diseños de investigación de tipo transversal y longitudinal. Para llevar a cabo este proyecto, se utilizó un abordaje de cinco vías, cada una de ellas representada por un estudio empírico que aborda las siguientes preguntas de investigación:

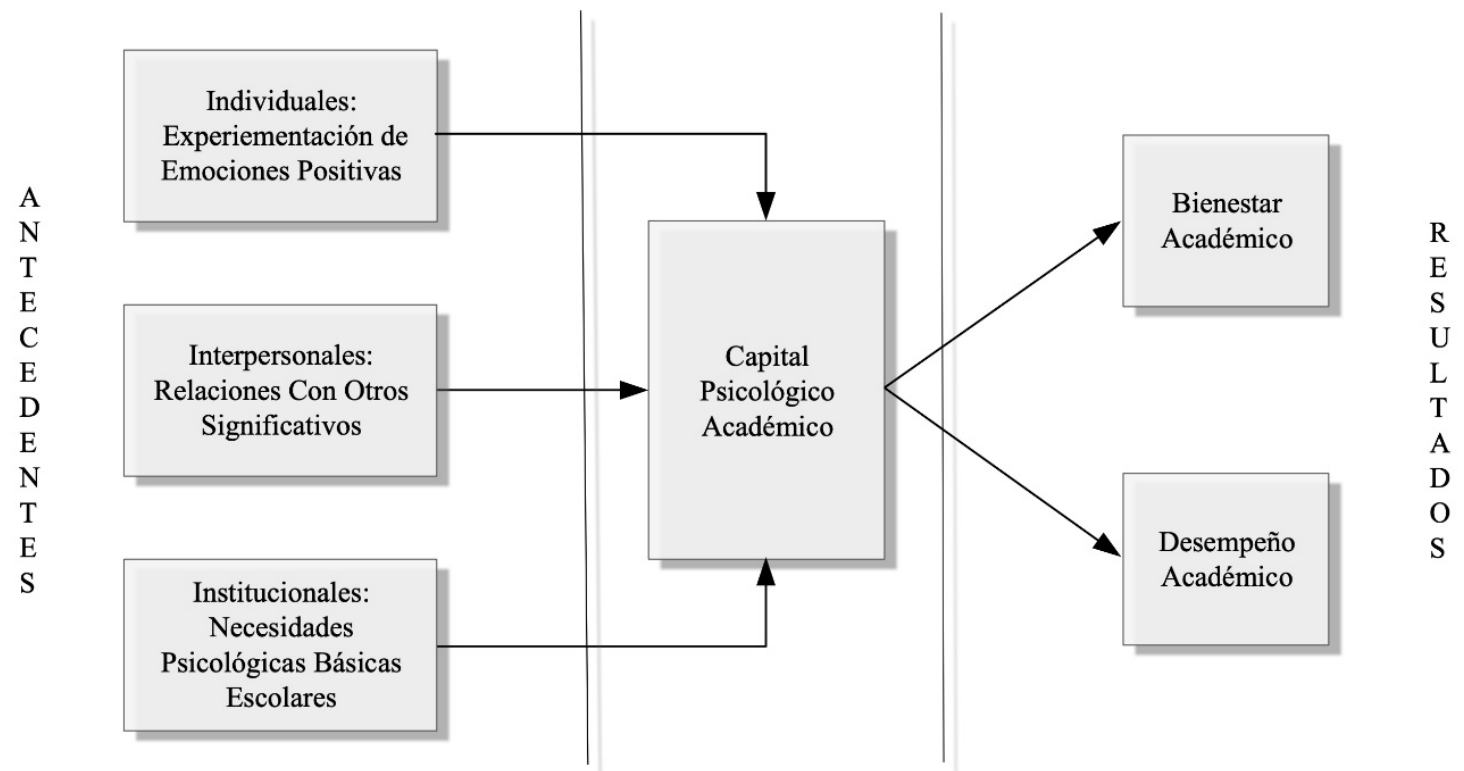

Figura 1 Modelo de Capital Psicológico Académico

Pregunta de Investigación $\mathbf{N}^{\circ} \mathbf{1}$ ¿Cómo influyen las características individuales positivas en la predicción del CP académico? Esta pregunta se aborda en dos estudios empíricos (capítulos 2 y 3 ) utilizando como característica individual la experimentación de emociones/experiencias académicas positivas, para lo cual se ha considerado como base teórica la broaden-and-build theory (B\&B) de Fredrikson (1998).

Pregunta de Investigación $\mathbf{N}^{\circ}{ }^{2}$ ¿Cómo influyen las relaciones interpersonales positivas en la predicción del CP académico? Esta pregunta se aborda en dos estudios empíricos utilizando como medida de relación interpersonal aquella entre profesores y estudiantes (capítulo 4) y entre padres e hijos (capítulo 5), para lo cual se ha considerado como base teórica la literatura previa que señala la importancia de otros significativos en la vida de los adolescentes (p.e. attachment theory y self-determination theory). 
Pregunta de Investigación $\mathbf{N}^{\circ} 3$ ¿Pueden las instituciones educativas favorecer la aparición del CP académico de sus estudiantes? Esta pregunta se aborda en un estudio empírico (capítulo 6) examinando la medida en que las escuelas satisfacen las necesidades psicológicas básicas de sus estudiantes, para lo cual se ha considerado como base teórica la self-determination theory de Deci y Ryan (2000).

Pregunta de Investigación $\mathbf{N}^{\circ} \mathbf{4}$ ¿Cómo influye la presencia del CP académico en el desarrollo de destrezas académicas y en el bienestar de los adolescentes? Esta pregunta se aborda en la totalidad de los estudios empíricos integrando las teorías ya mencionadas, utilizando como indicador de bienestar académico el constructo engagement (Schaufeli et al., 2002) y como indicador de desarrollo de destrezas académicas la media aritmética de calificaciones de los estudiantes (i.e., grade point average).

Los siguientes capítulos representan las versiones de cada uno de los artículos sometidos y/o publicados en revistas relevantes dentro de la disciplina psicológica y, finalmente, un último capítulo se dedica a las principales conclusiones del trabajo realizado, así como a las implicaciones teóricas y prácticas de los resultados obtenidos, comentando las limitaciones y direcciones futuras en torno al constructo aquí abordado.

\footnotetext{
${ }^{1}$ para evaluar el constructo CP se ha utilizado una adaptación al contexto académico del Psychological Capital Questionnaire (Luthans et al., 2007) en muestras de estudiantes españoles y chilenos realizada dentro del equipo de investigación WANT durante el desarrollo del proyecto de tesis (ver Martínez, Meneghel, Carmona-Halty, \& Youssef-Morgan, 2019).
} 


\section{Referencias}

Avey, J. B., Reichard, R. J., Luthans, F., \& Mhatre, K. H. (2011). Meta-analysis of the impact of positive psychological capital on employee attitudes, behaviours, and performance. Human Resources Development Quarterly, 22(2), 127-152.

Avolio, B. J., \& Luthans, F. (2006). The high impact leader: Moments matter for accelerating authentic leadership development. McGraw-Hill.

Bakker, A. B., \& Demerouti, E. (2007). The job demands-resources model: State of the art. Journal of Managerial Psychology, 22(3), 309-328.

Becker, G. (1993). Human Capital: A theoretical and empirical approach with special references to education. University of Chicago Press.

Bond, L., Butler, H., Thomas, L., Carlin, J., Glover, S., Bowes, G., \& Patton, G. (2007). Social and school connectedness in early secondary school as predictors of late teenage substance use, mental health, and academic outcomes. Journal of Adolescent Health, 40(4), 357 e9-18. https://doi.org/10.1016/j.jadohealth.2006.10.013

Carbonero, M. A., Martín-Antón, L. J., Otero, L., \& Monsalvo, E. (2017). Program to promote personal and social responsibility in the secondary classroom. Frontiers in Psychology, 8: 809. https://doi.org/10.3389/fpsyg.2017.00809

Datu, J. A. D., King, R. B., \& Valdez, J. P. (2016). Psychological capital bolster motivation, engagement, and achievement: Cross-sectional and longitudinal studies. Journal of Positive Psychology. https://doi.org/10.1080/17439760.2016.1257056

Datu, J. A. D., Labarda, C. E., \& Salanga, M. G. C. (2019). Flourishing is associated with achievement goal orientations and academic delay of gratification in a collectivist context. Journal of Happiness Studies. https://doi.org/10.1007/s10902-019-00122-w

Datu, J. A. D., \& Valdez, J. P. M. (2016). Psychological capital predicts academic engagement and well-being in Filipino high school students. The Asia Pacific Education Researcher, $25,399-405$.

Datu, J.A.D. \& Valdez, J.P.M. (2019). Psychological capital is associated with higher levels of 
life satisfaction and school belongingness. School Psychology International, 40, 331346. https://doi.org/10.1177/0143034319838011.

Demerouti, E., Bakker, A. B., \& Bulters, A. J. (2004). The loss spiral of work pressure, workhome interference and exhaustion: Reciprocal relations in a three-wave study. Journal of Vocational Behaviour, 64, 131-149. https://doi.org/10.1016/S0001-8791(03)00030-7

Fredrikson, B. (1998). What good are positive emotions? Review of General Psychology, 2(3), 300-319. https://doi.org/10.1037/1089-2980.2.3.300

Furrer, C., \& Skinner, E. (2003). Sense of relatedness as a factor in children's academic engagement and performance. Journal of Educational Psychology, 95, 148-162. https://doi.org/10.1037/0022-0663.95.1.148

Gallagher, M. W., Marques, S. C., \& López, S. J. (2016). Hope and the academic trajectory of college students. Journal of Happiness Studies.

Hamilton, S., \& Hamilton, M. (2009). The transition to adulthood: Challenges of poverty and structural lag. In R. Lerner \& L. Steinberg (Eds.), Handbook of Adolescent Psychology ( $3^{\text {a }}$ ed., pp. 492-526). Hoboken, NJ: John Wiley \& Sons. http://dx.doi.org/10.1002/9780470479193.adlpsy002015

Hobfoll, S. E. (1989). Conservation of resources: A new attempt at conceptualizing stress. American Psychologist, 44, 513-524. https://doi.org/10.1037/0003-066X.44.3.513

Jacobs, G. M. \& Renandya, W. A. (2019). Student Centred Cooperative Learning: Linking concepts in education to promote student learning. Springer, Singapore. https://doi.org/10.1007/978-981-13-7213-1

Luthans, F., Avolio, B. J., Avey, J. B., \& Norman, S. M. (2007). Positive psychological capital: Measurement and relationship with performance and satisfaction. Personnel Psychology, 60(3), 541-572. https://doi.org/10.1111/j.1744-6570.2007.00083.x

Luthans, B. C., Luthans, K. W., \& Jensen, S. M. (2012). The impact of business school students' psychological capital on academic performance. Journal of Education for Business, 87, 253-259. https://doi.org/10.1080/088322323.2011.609844

Luthans, F., \& Youssef-Morgan, C. M. (2004). Human, social, and now positive psychological 
capital management: Investing in people for competitive advantage. Organizational Dynamics, 33(2), 143-160. https://doi.org/10.1016/j.orgdyn.2004.01.003

Luthans, F., Youssef-Morgan, C. M., \& Avolio, B. J. (2007). Psychological Capital: Developing the human competitive edge. Oxford, England: Oxford University Press. Martin, A. J., Marsh, H. W., McInerney, D. M., Green, J., \& Dowson, M. (2007). Getting along with teachers and parents: The yields of good relationships for students' achievement motivation and self-esteem. Australian Journal of Guidance \& Counselling, 17(2), 109-125. https://doi.org/10.1375/ajgc.17.2.109

Martínez, I. M., Meneghel, I., Carmona-Halty, M., \& Youssef-Morgan, C. M. (2019). Adaptation and validation to Spanish of the Psychological Capital Questionnaire-12 (PCQ-12) in academic contexts. Current Psychology. https://doi.org/10.1007/s12144- 19-00276-7

Newman, A., Ucbasaran, D., Zhu, F., \& Hirst, G. (2014). Psychological capital: A review and synthesis. Journal of Organizational Behaviour, 35, 120-138. https://doi.org/10.1002/job.1916

Norrish, J. M., Williams, P., O'Connor, M., \& Robinson, J. (2013). An applied framework for positive education. International Journal of Wellbeing, 3(2), 147-161. https://doi.org/10.5502/ijw.v3i2.2

Ortega-Maldonado, A., \& Salanova, M. (2018). Psychological capital and performance among undergraduate students: the role of meaning-focused coping and satisfaction. Teaching in Higher Education, 23(3), 390-402. https://doi.org/10.1080/13562517.2017.1391199

Ouweneel, E. Le Blanc, P. M., \& Schaufeli, W. B. (2011). Flourishing students: A longitudinal study on positive emotions, personal resources and study engagement. Journal of Positive Psychology, 6(2), 142-153. https://doi.org/10.1080/17439760.2011.558847

Ouweneel, E., Le Blanc, P. M., Schaufeli, W. B., \& van Wijhe, C. I. (2012). Good morning, good day: A diary study on positive emotions, hope and work engagement. Human Relations, 65(9), 1129-1154. https://doi.org/10.1177/001872671142382

Ryan, R. M., \& Deci, E. L. (2000). Self-determination theory and the facilitation of intrinsic 
motivation, social development, and well-being. American Psychologist, 55, 68-78.

https://doi.org/10.1037/0003-066X.55.1.68

Salanova, M., Llorens, S., \& Schaufeli, W. B. (2010). "Yes, I can, I feel good, and I just do it!” On gain cycles and spirals of efficacy beliefs, affect, and engagement. Applied Psychology: An International Review. 60(2), 255-285. https://doi.org.10.1111/j.1464-0597.2010.00435.x

Salmela-Aro, K., \& Upadyaya, K. (2012). The schoolwork engagement inventory. European Journal of Psychological Assessment, 28, 60-67. https://doi.org.10.1027/1015-5759/a000091

Seligman, M. E. P., \& Csikszentmihalyi, M. (2000). Positive psychology: An introduction. American Psychologist, 55, 5-14. https://doi.org/10.1037/0003-066X.55.1.5

Seligman, M. E. P., Ernst, R. M., Gillham, J., Reivich, K., \& Linkins, M. (2009). Positive education: Positive psychology and classroom interventions. Oxford Review of Education, 35(3), 293-311. https://doi.org/10.1080/03054980902934563

Schaufeli, W. B., Martínez, I. M., Marques-Pinto, A., Salanova, M., \& Bakker, A. (2002). Burnout and engagement in university students: A cross-national study. Journal of Cross-Cultural Psychology, 33(5), 464-481. https://doi.org/10.1177/0013164405282471

Schoeps, K., Villanueva, L., Prado-Gascó, V. J., \& Montoya-Castilla, I. (2018). Development of emotional skills in adolescents to prevent cyberbullying and improve subjective well-being. Frontiers in Psychology, 9: 2050. https://doi.org/10.3389/fpsyg.2018.02050

Shoshani, A., \& Steinmetz, S. (2013). Positive psychology at school: A school-based intervention to promote adolescents' mental health and well-being. Journal of Happiness Studies, 15(6), 1289-1311. https://doi.org/10.1007/s10902-013-9476-1

Shoshani, A., \& Slone, M. (2017). Positive education for young children: Effects of a positive psychology intervention for preschool children on subjective well-being and learning behaviours. Frontiers in Psychology. https://doi.org/10.3389/fpsyg.2017.01866.

Siu, O. L., Bakker, A. B., \& Jiang, X. (2014). Psychological capital in university students: 
Relationship with study engagement and intrinsic motivation. Journal of Happiness Studies, 15, 979-994. https://doi.org/10.1007/s10902-013-94-59-2

Snyder, C. R., Shorey, H. S., Cheavens, J., Pulvers, K., M., Adams, V. H., \& Wiklund, C. (2002). Hope and academic success in college. Journal of Educational Psychology, 94(4), 820-826. https://doi.org/10.1037/0022-0663.94.4.820

Steinmayr, R., Heyder, A., Naumburg, C., Michels, J., \& Wirthwein, L. (2018). School-related and individual predictors of well-being and academic achievement. Frontiers in Psychology, 9:2631. https://doi.org/10.3389/fpsyg.2018.02631

Su, T., Tian, L., \& Huebner, E. S. (2019). The reciprocal relations among prosocial behaviour, satisfaction of relatedness needs at school, and subjective well-being in school: A threewave cross-lagged study among Chinese elementary school students. Current Psychology. https://doi.org/10.1007/s12144-019-00323-9

Widlund, A., Tuominen, H., \& Korhonen, J. (2018). Academic well-being, mathematics performance, and educational aspirations in lower secondary education: Changes within a school year. Frontiers in Psychology, 9: 2027. https://doi.org/10.3389/fpsyg.2018.00297

Xanthopoulou, D., Bakker, A. B., Demerouti, E., \& Schaufeli, W. B. (2009). Reciprocal relationships between job resources, personal resources and work engagement. Journal of Vocational Behaviour, 74(3), 235-244.

You, J. W. (2016). The relationship among college students' psychological capital, learning empowerment, and engagement. Learning and Individual Differences, 49, 17-24. https://doi.org/10.1016/j.lindif.2016.05.001

Zhang, Y., \& Chen, M. (2018). Character strengths, strengths use, future self-continuity and subjective well-being among Chinese university students. Frontiers in Psychology, 9:1040. https://doi.org/10.3389/fpsyh.2018.01040 




\title{
Chapter 2
}

\section{How Psychological Capital Mediates Between Study-related Positive Emotions and Academic Performance *}

\begin{abstract}
The present study, based on broaden-and-build theory, examines the relationship between study-related positive emotions and academic performance, and the mediating role of psychological capital in this relationship. A sample of 639 Chilean high school students between 14 and 17 years old was used. Through structural equation modelling (SEM), -as hypothesizeda statistically significant indirect effect was found between study-related positive emotions and academic performance via psychological capital. Students' study-related positive emotions were related to better academic performance through positive relationships with their levels of psychological capital (i.e., efficacy, hope, optimism, and resilience). Theoretical and practical implications of the results are discussed, limitations are mentioned, and future research directions are proposed.
\end{abstract}

Keywords positive emotions; psychological capital; academic performance

Marcos Carmona-Halty ${ }^{1}$

Marisa Salanova ${ }^{2}$

Susana Llorens ${ }^{2}$

Wilmar B. Schaufeli ${ }^{3,4}$

${ }^{1}$ Escuela de Psicología y Filosofía, Universidad de Tarapacá, Arica, Chile

${ }^{2}$ WANT Research Team, Universitat Jaume I, Castellón de la Plana, Spain

${ }^{3}$ Research Unit Occupational \& Organizational Psychology and Professional Learning, KU Leuven, Louvain, Belgium

${ }^{4}$ Department of Psychology, Utrecht University, Utrecht, The Netherlands

* Carmona-Halty, M., Salanova, M., Llorens, S., \& Schaufeli, W. B. (2019). How psychological capital mediates between study-related positive emotions and academic performance. Journal of Happiness Studies, 20(2), 605-617. https://doi.org/10.1007/s10902-018-9963-5 


\section{Introduction}

The recent shift from a negative perspective focused on problems and deficits to a more positive perspective focused on strengths and personal resources has aroused considerable attention in educational research (Seligman, Ernst, Gilham, Reivich, \& Linkins, 2009; Stiglbauer, Gnambs, Gamsjäger, \& Batinic, 2013). In this context, psychological capital (PsyCap) has begun to be assessed in educational settings (Datu, King, \& Valdez, 2016; Luthans, Luthans, \& Jensen, 2012; Siu, Bakker, \& Jiang, 2014; You, 2016). However, previous studies focused only on academic outcomes, and not on their antecedents. The broaden-and-build theory (B\&B; Fredrikson, 1998; 2001) offers a conceptual framework with which to understand how the experience of positive emotions may explain the presence of students' PsyCap (and other personal resources) and its direct and indirect impact on academic performance. However, we know very little about the interactions among these variables. The present study examines the mediator role of psychological capital between study-related positive emotions and academic performance in a sample of Chilean high school students.

\section{Positive Emotions and the B\&B Theory}

Positive emotions are brief, multisystem responses to some change in the way people interpret or appraise their current circumstances (Fredrikson, 2013). They arise when this multisystem register good prospects or good fortune. B\&B theory describes how positive emotions broaden awareness and helps to build (personal) resources (Fredrikson, 1998). The main assumption of $\mathrm{B} \& \mathrm{~B}$ theory is that positive emotions expand the array of thoughts, actions, urges, and dispositions that spontaneously come to mind (Fredrikson, 1998; 2001). That is, under the influence of positive emotions, people have greater perceptual access, wider semantic reach, more inclusive and connected social perceptions, and more relaxed and expansive bodily behaviour (Fredrikson, 2013). In addition, the function of the expansive form of positive emotions is to spur the development of personal resources, placing people on positive trajectories of growth (Fredrikson, 1998; 2001; 2013). In other words, by experiencing positive emotions, people will enhance their personal resources, which in turn, may lead to a more enduring positive state of 
well-being and future positive outcomes (Fredrikson, 2013; Fredrikson, Tugade, Waugh, \& Larkin, 2003; Lyubomirsky, King, \& Diener, 2005; Mauss et al., 2011).

The current study is based on this assumption of the B\&B theory, which is referred to as the "build hypothesis". This hypothesis states that the role of positive emotions is to build personal resources and produce well-being. Previous research has confirmed the association between positive emotions and personal resources. For example, using a diary study with university professors, Ouweneel, Le Blanc, Schaufeli, \& van Wijhe (2012) found that positive emotions predicted hope, which, in turn, was related to work engagement. Salanova, Llorens \& Schaufeli (2011), in two longitudinal studies with professors and students, reported that their beliefs of efficacy and engagement influenced each other through experiencing positive emotions. Xanthopoulou, Bakker, Demerouti, \& Schaufeli (2012) carried out a diary study showing that work resources influence personal resources through positive emotions. Using an undergraduate sample, Rogaten \& Moneta (2015) found a reciprocal relationship between positive emotions and creative cognition. Finally, Ouweneel, Le Blanc, \& Schaufeli (2011), in a longitudinal study with university students, showed that positive emotions predicted efficacy, hope and optimism, and these factors, in turn, predicted the components of academic engagement. Taken together, these empirical findings illustrate that the experience of positive emotions is important for understanding the emergence of personal resources.

\section{Psychological Capital}

Based on B\&B theory (Fredrikson, 1998) and Conservation of Resources (COR) theory (Hobfoll, 2002), Luthans \& Youssef-Morgan (2017) refer to PsyCap as a positive personal resource. PsyCap is defined as an "individual's positive psychological state of development characterized by: (1) having confidence (efficacy) to take on and put in the necessary effort to succeed at challenging tasks; (2) making a positive attribution (optimism) about succeeding now and in the future; (3) persevering toward goals and, when necessary, redirecting paths to goals (hope) in order to succeed; and (4) when beset by problems and adversity, sustaining and bouncing back and even beyond (resilience) to attain success" (Luthans, Youssef-Morgan, \& Avolio, 2015, p. 2). Although efficacy, optimism, hope, and resilience are conceptually distinct, 
these four components share common variance and are part of a synergistic set of resources consistent with the notion of resource caravans (Hobfoll, 2002). That is, these four components of PsyCap may "travel together" and interact synergistically to produce differentiated manifestations over time and across contexts (Luthans \& Youssef-Morgan, 2017).

Although considerable research about PsyCap has been carried out in industrialorganizational settings, some scholars argue that there are strong theoretical reasons to propose that PsyCap could also play a key role in the educational context (Datu et al., 2016; Siu et al., 2014). In addition, it has been proposed that previous research about its individual components (i.e., efficacy, optimism, hope, and resilience) may differ from research on a higher-order construct such as PsyCap (Datu et al., 2016). In this regard, recent research has assessed PsyCap at pre-professional levels (i.e., high school and undergraduate university students), finding direct associations with academic performance (Datu et al., 2016; Liao \& Liu, 2016; Vanno, Kaemkate, \& Wongwanich, 2014), intrinsic motivation (Siu et al., 2014), learning empowerment (Liao \& Liu, 2016; You, 2016), study engagement (Datu \& Valdez, 2016; Datu et al., 2016; Luthans et al., 2012; Siu et al., 2014; You, 2016), and student well-being (Datu \& Valdez, 2016).

\section{The Mediating Role of PsyCap Between Positive Emotions and Performance}

Previous research has shown that study-related emotions influence students' learning and achievement (Villavicencio \& Bernardo, 2012; 2013). As B\&B theory predicts, the effect of positive emotions on academic performance is mediated by cognitive-motivational variables (Pekrun, 1992; Pekrun, Goetz, Titz, \& Perry, 2002). Based on B\&B theory, we propose that PsyCap (a cognitive-motivational variable) is fostered by study-related positive emotions. This conjecture is supported, as mentioned above, by research that has demonstrated the relevance of positive emotions in the prediction of different personal resources (Ouweneel et al., 2011; Ouweneel et al., 2012; Salanova et al., 2011; Rogaten \& Moneta, 2015; Xanthopoulou et al., 2012) and research that identifies PsyCap as a predictor of academic performance (Datu et al., 2016; Liao \& Liu, 2016; Vanno et al., 2014). According to COR theory (Hobfoll, 1989), these results can be explained by the accumulation of psychological resources, which may promote positive outcomes such as higher academic performance. In addition, some research about 
individual components of PsyCap conducted in academic settings showed their relevance in a variety of school-related variables (Bong, 2011; Gallagher, Marques, \& Lopez, 2016; Hoy, Tarter, \& Hoy, 2006; Jiang, Song, Lee, \& Bong, 2014; Rand, Martin, \& Shea, 2011; Snyder et al., 2002).

In sum, the proposed mediation occurs because study-related positive emotions may facilitate the building of PsyCap, and in turn, these "resource caravans" would foster academic performance.

\section{Present Study}

The objective of this study is to investigate possible antecedents of PsyCap in an academic setting, and to provide empirical evidence on its role as a mediator between studyrelated positive emotions and academic performance. Based on the line of reasoning presented in the preceding paragraphs, the following hypothesis is formulated: PsyCap mediates the relationship between study-related positive emotions and academic performance.

\section{Method}

\section{Sample and Procedure}

The sample comprised 639 high school students attending three private educational institutions in Chile (each of them hosts approximately 700 students). Participants ranged in age from 14 to 17 years, and $51 \%$ of the sample were female. Of the 639 students, $30 \%$ were 14 years old, $18 \%$ were 15 years old, $30 \%$ were 16 years old, and $22 \%$ were 17 years old at the time of data collection.

Permission to conduct the study was granted by the school principals, the students, and the students' parents. The data collection was carried out in a group session ( 25 students each time) through an electronic procedure. Each student had a computer where the questionnaires were uploaded on a website especially designed for the research. Students took around 25 minutes to answer the questionnaire, and the data compilation took two weeks. 


\section{Measures}

Study-related positive emotions were measured using six items corresponding to two scales of positive emotions, 3 items on low-activation and 3 items on high-activation, from the Job-related Affective Well-being Scale (Van Katwyk, Fox, Spector, \& Kelloway, 2000), adapted to the academic context. Students answered using a Likert-type scale with scores from 1 (never) to 5 (always), reflecting how they feel about their studies. The adaptation of the items from the labour context to the academic context consisted of rewording the original reference to the job context (for example, "my job makes me feel at ease") to refer to the academic context (for example "my studies make me feel at ease").

Psychological capital was measured using an adaptation of the Psychological Capital Questionnaire (Avey, Avolio, \& Luthans, 2011) to the academic context. This questionnaire has 12 items that measure the four dimensions of the PsyCap construct on a Likert-type scale with scores from 1 (totally disagree) to 6 (totally agree): (1) three items correspond to the efficacy dimension (e.g. "I feel sure when sharing information about my studies with other people"); (2) two items correspond to the optimism dimension (e.g. "Concerning my studies, I'm optimistic about what the future offers me"); (3) four items correspond to the hope dimension (e.g. "Right now I see myself as being pretty successful in my studies"); and (4) three items correspond to the resilience dimension (e.g. "I usually take the stressful aspects of my studies in stride").

Academic performance was measured using the grade point average (GPA) provided by the educational institutions in two mandatory subjects in the Chilean education curriculum: maths and language/communication. The former includes content structured on four axes of evaluation: numbers, algebra, geometry, and data and probability. The latter includes contents structured on three axes of evaluation: oral communication, reading, and writing. According to the Chilean grading system, GPAs ranged from 1 (poor) to 7 (excellent). Both subjects are offered by semesters (March-June and July-November), with a total of six hours per week. For the objective of this study, the GPA was registered at the end of the semester before the data collection. 


\section{Data Analysis}

Preliminary analysis included means, standard deviations, and bivariate correlations conducted by IBM SPSS Statistics 21.0 and the omega index (McDonald, 1999) by MPLUS 7.1. The subsequent analysis was performed with AMOS 21.0. First, to examine the common method variance bias, Harman's single factor test was used (Podsakoff, MacKenzie, Lee, \& Podsakoff, 2003). Second, a SEM analysis was conducted to find out the structural relations in the hypothesized model (i.e., positive emotions $\rightarrow$ PsyCap $\rightarrow$ academic performance). We used maximum likelihood estimation methods, and the input for each analysis was the covariance matrix of the items. The goodness-of-fit of the model was evaluated using absolute and relative indexes: chi-square $\left(\chi^{2}\right)$ and normed $\chi^{2}$, Root-Mean-Squared Error of Approximation (RMSEA) with a confidence interval (90\%), Incremental Fit Index (IFI), Comparative Fit Index (CFI), Standardized Root Mean Residual (SRMR), and Akaike Information Criterion (AIC). To help evaluate the cut-off and determine model fit, we followed the guidelines published by the European Journal of Psychological Assessment (EJPA; Schweizer, 2010) and previous recommendations (Schreiber, Nora, Stage, Barlow, \& King, 2006). Third, we tested the statistical significance of the indirect effects by computing the bias-corrected and accelerated method (BCa) around the indirect effect obtained from a bootstrapping analysis. Finally, additional analysis was performed taking into account gender and age as control variables and an alternative direction of the flow model (i.e., PsyCap $\rightarrow$ positive emotions $\rightarrow$ academic performance); in addition, the mediating role of the PsyCap components takes into account high and low activation of the studyrelated positive emotions.

\section{Results}

\section{Preliminary Analysis}

Table 1 shows means, standard deviations, the omega index, and correlational coefficients among the variables. The internal consistencies obtained for the scales used was good, and the pattern of correlations revealed significant direct relationships for all measures in this sample. The results of Harman's single factor test obtained a fit index under the recommended 
fit standards (Schreiber et al., 2006; Schweizer, 2010), which means that this bias is not likely to affect the research data: $\chi^{2}=248.51 ; \chi^{2} / d f=12.42 ; \mathrm{IFI}=.86 ; \mathrm{CFI}=.86 ;=\mathrm{RMSEA}=.13,90 \%$ CI $[.11, .14]$; SRMR $=.07$; and $\mathrm{AIC}=280.51$. Therefore, the variance in the variables may be due to the psychosocial constructs being evaluated and not to the evaluation method.

Table 1

Mean (M), Standard Deviation (SD), Omega Index ( $\omega)$, and Correlations for the Study Variables

\begin{tabular}{lccccccc}
\hline & $\mathrm{M}$ & $\mathrm{SD}$ & $\omega$ & 1 & 2 & 3 & 4 \\
\hline 1. Positive emotions & 3.08 & .79 & .84 & - & & & \\
2. Academic PsyCap & 3.65 & .72 & .87 & $.60^{*}$ & & - & \\
3. Academic performance 1 & 5.13 & .90 & - & $.20^{*}$ & $.26^{*}$ & - & \\
4. Academic performance 2 & 5.82 & .52 & - & $.24 *$ & $.23^{*}$ & $.72 *$ & - \\
\hline
\end{tabular}

Notes: $*=\mathrm{p}<.001 ;{ }^{1}=$ mathematics subject; ${ }^{2}=$ language $/$ communication subject

\section{Structural Equation Modelling}

Study-related positive emotions, PsyCap, and academic performance are represented as latent variables in the structural model (Figure 1). Specifically, study-related positive emotions have two indicators, i.e., high-activation and low-activation; PsyCap has four indicators, i.e., efficacy, optimism, hope and resilience; and academic performance has two indicators, i.e., maths performance and language/communication performance. The goodness of fit indices for our represented model reached the recommended standard (Schreiber et al., 2006; Schweizer, 2010), explaining $57.2 \%$ of the PsyCap variance and $13.0 \%$ of the academic performance variance: $\chi^{2}=$ 93.23; $\chi^{2} / d f=5.48 ; \mathrm{IFI}=.96 ; \mathrm{CFI}=.96 ;=\mathrm{RMSEA}=.08,90 \% \mathrm{CI}[.06, .10] ; \mathrm{SRMR}=.04 ;$ and $\mathrm{AIC}=147.23$.

\section{Mediation Analysis}

Mediation involves a relationship in which an independent variable (X) impacts on a mediator (M), which, in turn, impacts on a dependent variable (Y). One can say that a relationship is mediated if: $\mathrm{X}$ is significantly related to $\mathrm{M}$ (testing for $a$ ); $\mathrm{M}$ is significantly related to $\mathrm{Y}$ after controlling for X (testing for $b$ ); and the indirect effect is statistically significant (testing for $a b$; MacKinnon, 2008). In addition, full mediation occurs when the introduction of the mediator M reduces the direct effect of $\mathrm{X}$ on $\mathrm{Y}$ to zero (i.e., non-significant direct effect), and partial 
mediation occurs when the introduction of the mediator $\mathrm{M}$ does not completely reduce the direct effect of X on Y (i.e., significant direct effect).

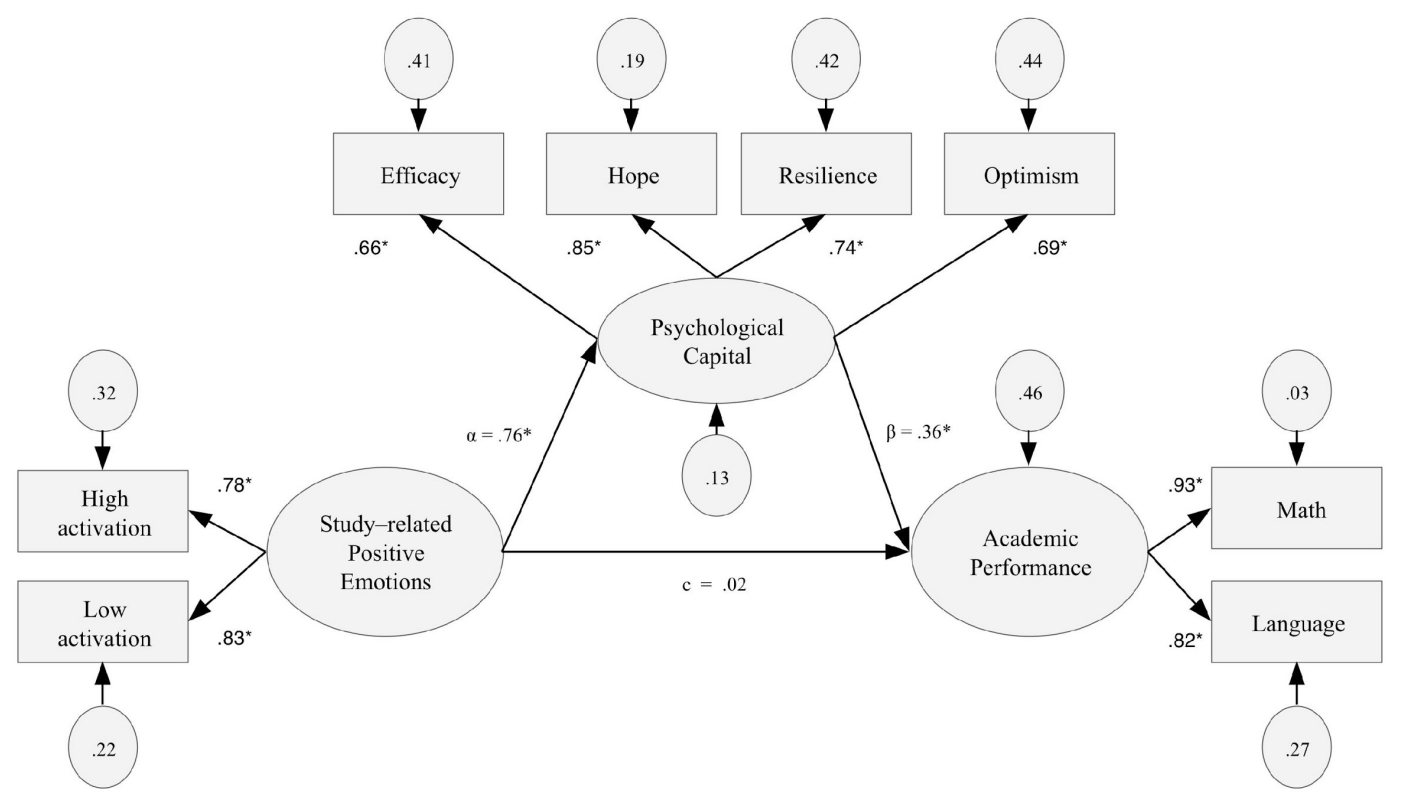

Figure 1 Simple mediation model showing the effect of study-related positive emotions on academic performance through psychological capital. Standardized coefficients are presented. ${ }^{*}=\mathrm{p}<.001$. Indirect effect $(a b)=.25^{*}$.

To examine the mediating role of PsyCap in our model (i.e., study-related positive emotions $\rightarrow$ PsyCap $\rightarrow$ academic performance), we implemented the bootstrapping procedure, one of the most valid and powerful methods for testing intervening variable effects (Williams \& MacKinnon, 2008). By following Hayes' (2009) recommendations, 5000 new samples were taken from our sample, and indirect effects were calculated. The results of this analysis led us to conclude that: study-related positive emotions are significantly related to PsyCap; $a=.75$; $\mathrm{SE}=$ .03 ; $95 \%$ BCa CI $[.69, .81]$; PsyCap is significantly related to academic performance after controlling for study-related positive emotions: $b=.34$; $\mathrm{SE}=.11 ; 95 \% \mathrm{BCa}$ CI $[.08, .52]$; studyrelated positive emotions are not significantly related to academic performance: $c=.02 ; \mathrm{SE}=.12$; $95 \% \mathrm{BCa}$ CI $[-.21, .28]$; and the indirect effect between study-related positive emotions and academic performance, via PsyCap, is statistically significant: $a b=.25 ; \mathrm{SE}=.08 ; 95 \% \mathrm{BCa} \mathrm{CI}$ $[.06, .40]$. Therefore, we can conclude that PsyCap fully mediates the relationship between studyrelated positive emotions and academic performance. 


\section{Additional Analysis}

As gender and age were significantly associated with study-related positive emotions and PsyCap, the analysis was performed again with these two control variables: $\chi^{2}=173.42 ; \chi^{2} / d f=$ 5.98; $\mathrm{IFI}=.94 ; \mathrm{CFI}=.94 ;=\mathrm{RMSEA}=.08,90 \% \mathrm{CI}[.07, .10] ; \mathrm{SRMR}=.05 ;$ and $\mathrm{AIC}=249.19$. This did not alter the results, with minimal changes in parameter estimates and explained variance in academic performance, and indirect significant effect was confirmed $(a b=.28 ; \mathrm{SE}=.04 ; 95 \%$ BCa CI $[.21, .36])$.

In order to assess the plausibility of the reverse order (i.e., PsyCap $\rightarrow$ study-related positive emotions $\rightarrow$ academic performance), an alternative model was run in which PsyCap acted as the predictor of academic performance, and study-related positive emotions were specified as the mediator. Results did not support this alternative model, as the indirect effect of PsyCap on academic performance through study-related positive emotions was not statistically significant $(a b=.01 ; \mathrm{SE}=.09 ; 95 \% \mathrm{BCa} \mathrm{CI}[-.16, .21])$.

Subscale analysis of the study-related positive emotions revealed a significant indirect effect between high activation $(a b=.22 ; \mathrm{SE}=.03 ; 95 \% \mathrm{BCa} \mathrm{CI}[.16, .28])$ and low activation $(a b$ $=.28 ; \mathrm{SE}=.03 ; 95 \% \mathrm{BCa} \mathrm{CI}[.21, .36])$ study-related positive emotions and academic performance via PsyCap. In addition, this significant indirect effect was found via each component of PsyCap: efficacy $(a b=.15 ; \mathrm{SE}=.03 ; 95 \%$ BCa CI $[.08, .23])$, optimism $(a b=.13$; $\mathrm{SE}=.04 ; 95 \% \mathrm{BCa} \mathrm{CI}[.06, .22])$, hope $(a b=.33 ; \mathrm{SE}=.03 ; 95 \% \mathrm{BCa} \mathrm{CI}[.28, .40])$, and resilience $(a b=.21 ; \mathrm{SE}=.03 ; 95 \% \mathrm{BCa}$ CI $[.14, .28])$.

\section{Discussion}

The objective of this study is to study the mediating role of PsyCap in the relationship between study-related positive emotions and academic performance. This study makes an innovative contribution due to the scarce research about the antecedents of PsyCap in academic settings and the lack of previous reports related to the interactions among study-related positive emotions, PsyCap, and objective academic performance, as assessed by student's GPA. 


\section{Theoretical Contributions}

First, we found that study-related positive emotions are directly associated with PsyCap. This means that students, who experience a higher frequency of positive emotions in their studies, whether of high or low activation, are more likely to report high levels of PsyCap. This result is coherent with the B\&B theory, which emphasizes the role of experiencing positive emotions in generating the development of new psychological resources (in our case, PsyCap), and the derived effects of experiencing positive emotions emerge regardless of their level of arousal (Fredrikson, 2003). In sum, our finding confirms that positive emotions are one of the key mechanisms through which PsyCap operates (Luthans \& Youssef-Morgan, 2017).

Second, we found that PsyCap is directly associated with academic performance. This means that students who report higher levels of PsyCap are more likely to obtain high levels of academic performance (i.e. GPA). This result agrees with previous research in academic settings emphasizing the role of PsyCap in academic engagement, academic motivation, and academic performance (Datu et al., 2016; Liao \& Liu, 2016; Vanno et al., 2014). In addition, subscale analysis showed that the PsyCap component that had the greatest effect on academic performance was hope. This result is consistent with previous studies that reported direct associations between hope and academic performance (Gallagher et al., 2016; Rand et al., 2011), and it might be explained by the fact that high-hope students are attuned to their own goals, in control of how they will pursue them, and intrinsically motivated (Conti, 2000; Snyder et al., 2002).

Third, we found that study-related positive emotions are indirectly associated with academic performance via PsyCap. This result suggests that experiencing positive emotions (study-related in our research) expands thinking and action tendencies, favouring the later building of personal resources (PsyCap in our research) that would be used to face challenging or difficult situations in the academic context. Although some authors have proposed that positive emotions mediate between academic performance and cognitive-motivational variables (Pekrun, Elliot, \& Maier, 2009; Villavicencio, 2011; Villavicencio \& Bernardo, 2012; 2013), our results did not support this alternative direction because the indirect effect of PsyCap on academic performance via study-related positive emotions was not statistically significant. However, this 
alternative direction has been explained by the $\mathrm{B} \& \mathrm{~B}$ theory as the positivity-triggered upward spiral process. That is, initial levels of positive emotions predicted later levels of positive emotions, partly through changes in personal resources; likewise, initial levels of personal resources predicted later levels of personal resources, partly through changes in positive emotions (Fredrikson, 2013; Fredrikson \& Joiner, 2002; Salanova, Bakker, \& Llorens, 2006).

Fourth, our results may also be explained by referring to the concept of mental capital (Kirkwood, Bond, May, McKeith, \& The, 2008). This construct refers to the totality of a person's cognitive and emotional resources. That is, mental capital reflects people's basic endowment and experiences that take place throughout life. From this point of view, our results suggest that, in the formative years of mental capital, positive emotions play an important role in building it up. More specifically, study-related positive emotions may serve to build up certain behaviours included in the mental capital construct, such as flexibility and efficiency in learning, and resilience or perseverance when faced with stress and failure. This is a significant result that complements the current literature on possible ways to enhance mental capital, for example, by including the promotion of emotional experiences in educational or positive youth development programmes (see Kirkwood et al., 2008).

\section{Practical Implications}

First, based on the role of positive emotions, teachers could generate a climate in their classroom that promotes this experience. For example, among other alternatives, planning the path to success can be addressed. It is possible to promote internal attributions about the achieved performance (Salanova, Martínez, \& Llorens, 2012); or training activities can be carried out, oriented toward continuous learning and avoiding failure, with an appropriate attitude, and persevering when failure is present. Also, teachers can encourage students and provide them with positive feedback, thereby stimulating positive emotions. This may, increase their personal resources, which promotes their well-being right away, and play a role in behavioural reinforcement. In addition, according to Deci \& Ryan (2002), on seeing the effort from students in performing specific tasks or in learning, teachers could encourage them by satisfying their basic 
needs for autonomy, competence, and relatedness, which is likely to enhance the experience of study-related positive emotions and positive outcomes.

Second, a key feature of PsyCap is that it is state-like and open to development through instructional programs (Luthans \& Youssef-Morgan, 2017). Thus, a PsyCap intervention (PCI) training model (Luthans, Avey, Avolio, Norman, \& Combs, 2006) has shown the possibility of developing PsyCap in working adults (Luthans, Avey, \& Patera, 2008) and undergraduate university students (Luthans, Avey, Avolio, \& Peterson, 2010). The PCI focuses on developing the four psychological resources of PsyCap using four groups of different techniques: a) acquiring and modifying self-efficacy beliefs; b) developing realistic, constructive, and accurate beliefs; c) designing goals, pathway generation, and strategies for overcoming obstacles; and d) asset factors, risk factors, and influence processes. Each of these four groups can be adapted for the development of students' PsyCap, which is likely to favour high levels of academic performance.

\section{Limitations and Future Research}

There are two major limitations in this research. First, this is a cross-sectional study, which keeps us from establishing the causality of the observed phenomenon. It is possible that students with higher levels of PsyCap would, at the same time, also experience study-related positive emotions more often; in the same way, having high academic performance can be the origin of the later emergence of PsyCap in students. However, we tested an alternative direction model (i.e., PsyCap $\rightarrow$ positive emotions $\rightarrow$ academic performance), and this possibility is unlikely in our sample. Additionally, our results agree with B\&B theory (Fredrikson, 1998; 2001), specifically with the build hypothesis, which has been confirmed through longitudinal designs (Salanova et al., 2011; Ouweneel et al., 2011) and diary studies (Ouweneel et al., 2012; Xanthopoulou et al., 2012), suggesting causality. Second, we used self-report measures for emotions and PsyCap, which could have produced common method bias variance. However, to eliminate this possibility, we used Harman's single factor test. Results show that there is no single factor that explains the variance in the data. In addition, as an outcome variable, we included an objective measure of academic performance in our model, so that the menace of common method bias is unlikely. 
The limitations could be considered fruitful research lines in the future. First, the proposed model could be examined from a longitudinal approach. Furthermore, it would be important to add other meaningful constructs such as school engagement and academic satisfaction. Along these lines, considering the circumplex model of emotions (Russel, 1980; Warr, 1994), school engagement and academic satisfaction can be directly associated with highactivation and low-activation positive emotions, respectively (Bakker \& Oerlemans, 2011). Future research could add these constructs to PsyCap and examine their mediating role between study-related positive emotions and academic performance. Second, in addition to including objective measures of academic performance, it would be interesting to incorporate the teacher's perception of the students' positive emotions, personal resources, school engagement, and academic satisfaction. Moreover, teachers' own personal resources or engagement levels could be included in the model by examining their role in the positive emotions and personal resources of their students. 


\section{References}

Avey, J. B., Avolio, B. J., \& Luthans, F. (2011). Experimentally analysing the impact of leader positivity on follower positivity and performance. The Leader Quarterly, 22, 282-294. https://doi.org/10.1016/j.leaqua.2011.02.004

Bakker, A. B., \& Oerlemans, W. (2011). Subjective well-being in organization. In K.S. Cameron, \& G. M. Spreitzer (eds), The Oxford Handbook of Positive Organizational Scholarship (pp.178-189). New York: Oxford University press. https://doi.org/10.1093/oxfordhb/9780199734610.013.0014

Bong, M. (2001). Role of self-efficacy and task-value in predicting college students' course performance and future enrolment intentions. Contemporary Educational Psychology, 26, 553-570. https://doi.org/10.1006/ceps.2000.1048

Conti, R. (2000). College goals: Do self-determined and carefully considered goals predict intrinsic motivation, academic performance, and adjustment during the first semester? Social Psychology of Education, 4, 189-211. https://doi.org/10.1023/A:1009607907509

Datu, J. A. D., King, R. B., \& Valdez, J. P. (2016). Psychological capital bolsters motivation, engagement, and achievement: Cross-sectional and longitudinal studies. The Journal of Positive Psychology. https://doi.org/10.1080/17439760.2016.1257056

Datu, J. A. D., \& Valdez, J. P. M. (2016). Psychological capital predicts academic engagement and well-being in Filipino high school students. The Asia-Pacific Education Researcher, 25(3), 399-405. https://doi.org/10.1007/s40299-015-0254-1

Deci, E. L., \& Ryan, R. M. (2002). Handbook of Self-determination Research. Rochester, NY: The University of Rochester Press.

Fredrikson, B. L. (1998). What good are positive emotions? Review of General Psychology, 2(3), 300-319. https://doi.org/10.1037/1089-2680.2.3.300

Fredrikson, B. L. (2001). The role of positive emotions in positive psychology: The broadenand-build theory of positive emotions. American Psychologist, 56(3), 218-226. https://doi.org/10.1037/0003-066X.56.3.218

Fredrikson, B. L. (2003). Positive emotions and upward spirals in organization. In K. Cameron, 
J. Dutton, \& R. Quinn (Eds.), Positive Organizational Scholarship. (p.163-175). San Francisco, CA: Berrett-Koehler.

Fredrikson, B. L. (2013). Positive emotions broaden and build. Advances in Experimental Social Psychology, 47, 1-53. https://doi.org/10.1016/B978-0-12-407236-7.00001-2

Fredrikson, B. L., \& Joiner, T. (2002). Positive emotions trigger upward spirals toward emotional well-being. Journal of Personality and Social Psychology, 65, 45-55. https://doi.org./10.1111/1467-9280.00431

Fredrikson, B. L., Tugade, M. M., Waugh, C. E., \& Larkin, G. R. (2003). What good are positive emotions in crises? A prospective study on resilience and emotions following the terrorist attacks on the United States on September $11^{\text {th }}, 2001$. Journal of Personality \& Social Psychology, 84, 365-376. https://doi.org/10.1037/0022-3514.84.2.365

Gallagher, M. W., Marques, S. C., \& Lopez, S. J. (2016). Hope and the academic trajectory of college students. Journal of Happiness Studies. https://doi.org.10.1007/s10902-016-9727-Z

Hayes, A. F. (2009). Beyond baron and Kenny: Statistical mediation analysis in the new millennium. Communication Monographs, 76(4), 408-420. https://doi.org/10.1080/03637750903310360

Hobfoll, S. E. (1989). Conservation of resources: A new attempt at conceptualizing stress. American Psychologist, 44, 513-524. https://doi.org.10.1037/0003-066X.44.3.513

Hobfoll, S. E. (2002). Social and psychological resources and adaptation. Review of General Psychology, 6(4), 307-324. https://doi.org/10.1037//1089-2680.6.4.307

Hoy, A. W., Tarter, C. J., \& Hoy, W. K. (2006). Academic optimism of schools: A force student achievement. American Education Research Journal, 43, 425-446. https://doi.org/10.1016/j.sbspro.2010.12.261

Jiang, Y., Song, J., Lee, M., \& Bong, M. (2014). Self-efficacy and achievement goals as motivational links between perceived contexts and achievement. Educational Psychology, 34, 92-117. https://doi.org/10.1080/01443410.2013.863831 
Kirkwood, T., Bond, J., May, C., McKeith, I., \& The, M. (2008). Foresight Mental Capital Wellbeing Project. Mental capital through life: Future challenges. The Government Office for Science, London.

Liao, R. \& Liu, Y. (2016). The impact of structural empowerment and psychological capital on competence among Chinese baccalaureate nursing students: A questionnaire survey. Nurse Education Today, 36, 31-36. https://doi.org/10.1016/j.nedt.2015.07.003

Liu, C., Zhao, Y., Tian, X., Zou, G., \& Li, P. (2015). Negative life events and school adjustment among Chinese nursing students: The mediating role of psychological capital. Nurse Education Today, 35(6), 754-759. https://doi.org/10.1016/j.nedt.2015.02.002

Luthans, F., Avey, J. B., Avolio, B. J., Norman, S. M., \& Combs, G. M. (2006). Psychological capital development: Toward a micro-intervention. Journal of Organizational Behaviour, 27, 387-393. https://doi.org/10.1002/job.373

Luthans, F., Avey, J. B., Avolio, B. J., \& Peterson, S. (2010). The development and resulting performance impact of positive psychological capital. Human Resources Development Quarterly, 21, 41-66. https://doi.org/10.1002/hrdq.20034

Luthans, F., Avey, J. B., \& Patera, J. L. (2008). Experimental analysis of a web-based training intervention to develop positive psychological capital. Academy of Management Learning \& Education, 7(2), 209-221. https://doi.org/10.5465/AMLE.2008.32712618

Luthans, B. C., Luthans, K. W., \& Jensen, S. M. (2012). The impact of business school students' psychological capital on academic performance. Journal of Education for Business, 87, 253-259. https://doi.org/10.1080/08832323.2011.609844

Luthans, F., \& Youssef-Morgan, C. M. (2017). Psychological capital: An evidence-based positive approach. Annual Review of Organizational Psychology and Organizational Behaviour. https://doi.org/10.1146/annurev-orgpsych-032516-113324

Luthans, F., Youssef-Morgan, C. M., \& Avolio, B. (2015). Psychological Capital and Beyond. New York: Oxford University Press.

Lyubomirsky, S., King, L., \& Diener, E. (2005). The benefits of frequent positive affect: Does happiness lead to success? Psychological Bulletin, 131(6), 803-855. 
https://doi.org/10.1037/0033-2909.131.6.803

McDonald, R. P. (1999). Test theory: A unified treatment. Mahwah, NJ: Erlbaum.

Mauss, I. B., Shallcross, A. J., Troy, J., John, O., Ferrer, E., Wilhelm, F., \& Gross, J. J. (2011). Don`t hide your happiness! Positive emotion dissociation, social connectedness, and psychological functioning. Journal of Personality and Social Psychology, 100(4), 738748. https://doi.org/10.1037/a0022410

Ouweneel, E., Le Blanc, P. M., \& Schaufeli, W. B. (2011). Flourishing students: A longitudinal study on positive emotions, personal resources and study engagement. The Journal of Positive Psychology, 6(2), 142-153. https://doi.org/10.1080/17439760.2011.558847

Ouweneel, E., Le Blanc, P. M., Schaufeli, W. B., \& van Wijhe, C. I. (2012). Good morning, good day: A diary study on positive emotions, hope and work engagement. Human Relations, 65(9), 1129-1154. https://doi.org/10.1177/0018726711429382

Pekrun, R. (1992). The impact of emotions on learning and achievement: Towards a theory of cognitive/motivational mediators. Applied Psychology: An International Review, 41(4), 359-376. https://doi.org/10.1111/j.1464-0597.1992.tb00712.x

Pekrun, R., Elliot, A. J., \& Maier, M. A. (2009). Achievement goals and achievement emotions: testing a model of their joint relations with academic performance. Journal of Educational Psychology, 101, 115-135. https://doi.org/10.1037/a0013383

Pekrun, R., Goetz, T., Titz, W., \& Perry, R. P. (2002). Academic emotions in students' selfregulated learning and achievement: A program of qualitative and quantitative research. Educational Psychologist, 37(2), 91-105. https://doi.org/10.1207/s15326985ep3702 4

Podsakoff, P. M., MacKenzie, S. B., Lee, J. Y., \& Podsakoff, N. P. (2003). Common method biases in behavioural research: A critical review of the literature and recommended remedies. Journal of Applied Psychology, 88 (5), 879-903. https://doi.org/10.1037/0021-9010.88.5.879

Rand, K. L., Martin, A. D., \& Shea, A. M. (2011). Hope, but not optimism, predicts academic performance of law students beyond previous academic achievement. Journal of Research in Personality, 45, 683-686. https://doi.org/10.1016/j.jrp.2011.08.004 
Rogaten, J., \& Moneta, G. B. (2015). Use of creative cognition and positive affect in studying: Evidence of a reciprocal relationship. Creativity Research Journal, 27(2), 225-231. https://doi.org/10.1080/10400419.2015.1030312

Russell, J. A. (1980). A circumplex model of affect. Journal of Personality and Social Psychology, 39, 1161-1178. https://doi.org/10.1037/h0077714

Salanova, M., Bakker, A. B., \& Llorens, S. (2006). Flow at work: Evidence for an upward spiral of personal and organizational resources. Journal of Happiness Studies, 7, 1-22. https://doi.org/10.1007/s10902-005-8854-8

Salanova, M., Llorens, S., \& Schaufeli, W. B. (2011). "Yes, I can, I feel good, and I just do it!" On gain cycles and spirals of efficacy beliefs, affect and engagement. Applied Psychology: An International Review, 60(2), 255-285. https://doi.org/10.1111/j.1464-0597.2010.00435.x

Salanova, M., Martínez, I., \& Llorens, S. (2012). Success breeds success, especially when selfefficacy is related with an internal attribution of causality. Studies In Psychology, 33(2), 151-165. https://doi.org/10.1174/021093912800676420

Schreiber, J. B., Nora, A., Stage, F. K. Barlow, E., \& King, J. (2006). Reporting structural equation modelling and confirmatory factor analysis results: A review. The Journal of Educational research, 99(6), 323-338. https://doi.org/10.3200/JOER.99.6.323-338

Schweizer, K. (2010). Some guidelines concerning the modelling of traits and abilities in test construction. European Journal of Psychological Assessment, 26, 1-2. https://doi.org/10.1027/1015-5759/a000001

Seligman, M. E. P., Ernst, R. M., Gillham, J. Reivich, K., \& Linkins, M. (2009). Positive education: Positive psychology and classroom interventions. Oxford Review of Education, 35(3), 293-311. https://doi.org/10.1080/03054980902934563

Siu, O. L., Bakker, A. B., \& Jiang, X. (2014). Psychological capital among university students: Relationship with study engagement and intrinsic motivation. Journal of Happiness Studies, 15, 979-994. https://doi.org/10.1007/s10902-013-9459-2 
Snyder, C. R., Shorey, H. S., Cheavens, J., Pulvers, K. M., Adams, V. H., \& Wiklund, C. (2002). Hope and academic success in college. Journal of Educational Psychology, 94(4), 820-826. https://doi.org/10.1037/0022-0663.94.4.820

Stiglbauer, B., Gnambs, T. Gamsjäger, M., \& Batinic, B. (2013). The upward spiral of adolescents' positive school experiences and happiness: Investigating reciprocal effects over time. Journal of School Psychology, 51(2), 231-242. https://doi.org/10.1016/j.jsp.2012.12.002

Vanno, V., Kaemkate, W., \& Wongwanich, S. (2014). Relationships between academic performance, perceived group psychological capital and positive psychological capital of Thai undergraduate students. Social and Behavioural Sciences, 116, 3226-3230. https://doi.org/10.1016.j.sbspro.2014.01.793

Van Katwyk, P. T., Fox, S., Spector, P. E., \& Kelloway, E. K. (2000). Using the job-related affective well-being scale (JAWS) to investigate affective responses to work stressors. Journal of Occupational Health Psychology, 5(2), 219-230. https://doi.org/10.1037/1076-8998.5.2.219

Villavicencio, F. T. (2011). Critical thinking, negative academic emotions and achievement: A mediational analysis. The Asia-Pacific Education Researcher, 20, 118-126.

Villavicencio, F. T., \& Bernardo, A. B. I. (2012). Positive academic emotions moderate the relationship between self-regulation and academic achievement. British Journal of Educational Psychology, 83, 329-340.

https://doi.org/10.1111/j.2044-8279.2012.02064.x

Villavicencio, F. T., \& Bernardo, A. B. I. (2013). Negative emotions moderate the relationship between self-efficacy and achievement of Filipino students. Psychological Studies, 58(3), 225-232. https://doi.org/10.1007/s12646-013-0193-y

Warr, P. (1994). A conceptual framework for the study of work and mental health. Work \& Stress, 8, 84-97. https://doi.org/10.1080/02678379408259982 
Williams, J., \& MacKinnon, D. P. (2008). Resampling and distribution of the product methods for testing indirect effects in complex models. Structural Equation Modelling, 15, 2351. https://doi.org/10.1080/10705510701758166

You, J. (2016). The relationship among college student's psychological capital, learning empowerment, and engagement. Learning and Individual Differences, 49, 17-24. https://doi.org/10.1016/j.lindif.2016.05.001

Xanthopoulou, D., Bakker, A. B., Demerouti, E., \& Schaufeli, W. B. (2012). A diary study on the happy worker: How job resources relate to positive emotions and personal resources. European Journal of Work and Organizational Psychology, 21(4), 489-517. https://doi.org/10.1080/1359432X.2011.584386 



\title{
Chapter 3
}

\section{Linking Positive Emotions and Academic Performance: The Mediated Role of Academic Psychological Capital and Academic Engagement *}

\begin{abstract}
The present study examined the relationship between positive emotions and academic performance, and the mediated role played by academic psychological capital and academic engagement, in a sample of 497 Chilean high school students. Participants' ages ranged from 14 to 17 years old, with a mean of $15.71(\mathrm{SD}=1.15)$. Findings supported our hypothesized model that academic psychological capital and academic engagement mediate the relationship between positive emotions and academic performance (GPA). The proposed model has theoretical implications for future research and practical implications for school settings. The promotion of positive emotions in students is a relevant challenge for principals, teachers, and parents in attempting to build academic psychological capital and academic engagement, which in turn may lead to higher academic performance.
\end{abstract}

Keywords positive emotions; academic PsyCap; academic engagement; |performance

\author{
Marcos Carmona-Halty ${ }^{1}$ \\ Marisa Salanova $^{2}$ \\ Susana Llorens ${ }^{2}$ \\ Wilmar B. Schaufeli ${ }^{3,4}$ \\ ${ }^{1}$ Escuela de Psicología y Filosofía, Universidad de Tarapacá, Arica, Chile \\ ${ }^{2}$ WANT Research Team, Universitat Jaume I, Castellón de la Plana, Spain \\ ${ }^{3}$ Research Unit Occupational \& Organizational Psychology and Professional Learning, KU \\ Leuven, Louvain, Belgium \\ ${ }^{4}$ Department of Psychology, Utrecht University, Utrecht, The Netherlands
}

\footnotetext{
* Carmona-Halty, M., Salanova, M., Llorens, S., \& Schaufeli, W. B. (2019). Linking positive emotions and academic performance: the mediated role of academic psychological capital and academic engagement. Current Psychology. https://doi.org/10.1007/s12144-019-00227-8
} 


\section{Introduction}

Interest in Positive Psychology and its applications in educational settings has grown exponentially in recent years (Stiglbauer, Gnambs, Gamsjäger, and Batinic, 2013). Special attention has been paid to the way positive emotions shape academic engagement and performance (Linnenbrik-Garcia \& Pekrun, 2011; Pekrun \& Linnenbrik-Garcia, 2012). In addition, some scholars have found that psychological capital (PsyCap) -a concept that was initially examined in work settings, and simultaneously encompasses efficacy, optimism, hope, and resilience- may play an important role in facilitating desirable student outcomes (Luthans, Luthans, and Jensen, 2012). However, studies in the field have mainly been conducted in undergraduate university students, and none of them have focused on its antecedents. Thus, more research is needed to assess: 1) the applicability of academic PsyCap in school settings and 2) the possible antecedents of academic PsyCap.

The current study addresses both issues by proposing a theory-driven model -based on the broaden-and-build (or B\&B) theory (Fredrikson, 1998) and the conservation of resources (or COR) theory (Hobfoll, 2002) - to examine how positive emotions predict the appearance of personal resources, such as academic PsyCap, which, in turn, enhances desirable outcomes such as academic engagement and academic performance. In other words, the aim of the study is to examine the indirect relationship between positive emotions and academic performance through sequential mediation by academic PsyCap and academic engagement, respectively. Providing empirical evidence about the possible antecedents of academic PsyCap and its applicability in a school setting may make an important contribution to understanding how high school students build personal resources, making it possible to develop evidence-based future interventions designed to enhance students' academic PsyCap and academic well-being.

\section{Positive Emotions and the B\&B Theory}

Research on positive emotions has increased since the emergence of Positive Psychology, and a landmark in its development was the appearance of the B\&B theory (Fredrikson, 1998). This theory specifies two main hypotheses: the "broaden hypothesis" and the "build hypothesis". According to the broaden hypothesis, positive emotions temporarily "broaden" people's attention 
and thoughts, giving them the capacity to access a wider range of ideas. In turn, and according to the second hypothesis, these broadened outlooks help people to discover and "build" important personal resources (Fredrikson, 2001).

The current study focuses on the second assumption of broaden-and-build theory. People who experience and express positive emotions show an increase in their personal resources and are more likely to function at optimal levels and show high performance (Fredrikson, 2013). For example, Oriol-Granado, Mendoza-Lira, Covarrubias-Apablaza, and Molina-López (2017) found that positive emotions influence self-efficacy and academic engagement, which, in turn, predict academic performance. Furthermore, Ouweneel, Le Blanc, and Schaufeli (2011) reported that students' experiences of positive emotions predict their future personal resources, such as optimism and hope, which, in turn, predict their future academic engagement. Finally, Salanova, Llorens, and Schaufeli (2011) found that efficacy beliefs reciprocally influence academic engagement indirectly through their impact on positive affect.

Taken together, empirical evidence shows that positive emotions can play a relevant role in explaining how students build their personal resources and, thus, seems to confirm the "build" hypothesis. The explanation here is that positive emotions are associated with approach-oriented behaviour (Elliot \& Thrash, 2002). That is, when students are in a positive mood, they are more likely to explore novel situations, interact with other people, have higher expectations about attaining academic-related goals, and pursue new goals (Carver, 2003).

Despite the attention research has paid to examining how positive emotions are associated with each individual dimension of PsyCap (e.g., efficacy: Oriol-Granado et al., 2017; Salanova et al., 2011; hope, efficacy and optimism: Ouweneel et al., 2011), there is limited research on the link between positive emotions and the entire higher-order PsyCap construct. That is, previous studies in the field have investigated PsyCap only partly and incompletely, which is an important limitation because PsyCap may have a different nomological network for each of its four components (Datu, King, and Valdez, 2016). In other words, it may be premature to consider that previous evidence about its individual components (i.e., efficacy, optimism, hope, and resilience) will be equivalent if we consider the entire PsyCap construct. 
Thus, based on Luthans and Youssef-Morgan (2017) and the research, we propose that positive emotions may be a key mechanism through which academic PsyCap operates.

\section{Academic PsyCap and the COR Theory}

PsyCap is an individual's positive psychological state of development characterized by efficacy, optimism, hope, and resilience (Luthans, Youssef-Morgan, and Avolio, 2015). Efficacy refers to having enough confidence to accept and put in the necessary effort to succeed at challenging tasks. Optimism refers to making a positive attribution about succeeding now and in the future. Hope refers to persevering on goals and, when necessary, redirecting paths toward goals in order to succeed. Resilience refers to holding on and bouncing back, and even beyond, to attain success when facing problems and adversity (Avolio \& Youssef-Morgan, 2017).

According to COR theory, resources do not exist in isolation because people try to accumulate as many resources as possible (Hobfoll, 1989). An example of a combination of personal resources (so-called resource caravans) is the PsyCap construct. Previous research showed that it explains significant variance in desirable psychological outcomes in work settings, such as job satisfaction, organizational commitment, and citizenship (for a meta-analytic revision, see Avey, Reichard, Luthans, and Mhatre, 2011). According to conservation of resources theory, this occurs because a person who can draw on many resources has the ability to solve problems that can arise in stressful situations, and s/he is likely to remain engaged during goal pursuit (Hobfoll, 2002; Hobfoll, Halbesleben, Neveu, and Westman, 2018).

Recently, the beneficial role of academic PsyCap in facilitating positive student outcomes was reported. For example, Luthans et al. (2012) found a positive relationship between academic PsyCap and academic performance in US university students. In a similar sample, Riolli, Savicki, and Richards (2012) showed that academic PsyCap mediated between stress and psychological symptoms. Liao and Liu (2015) reported a positive relationship between academic PsyCap and competence in Chinese university students. Also, in a Chinese sample, Liu, Zhao, Tian, Zou, and Li (2015) reported a positive relationship between academic PsyCap and academic adjustment. Finally, Siu, Bakker, and Jiang (2014) established a reciprocal relationship between academic PsyCap and academic engagement (i.e., vigor, dedication, and absorption). In a school setting, 
Datu et al. (2016) reported that academic PsyCap improves motivation, cognitive and affective engagement, and achievement in a sample of students from the Philippines. Finally, also in a Philippine sample, Datu and Valdez (2016) reported that academic PsyCap predicts flourishing, interdependent happiness, and positive affect.

Taken together, these studies show that academic PsyCap is a key resource that enhances students' ability to develop. The reason for this is that PsyCap facilitates positive cognitive appraisals of events and the processes necessary for attention, interpretation, and retention of positive and constructive memories that lead to well-being and success (Luthans \& YoussefMorgan, 2017). However, further research would make it possible to assess whether the PsyCap construct can be applied in a school setting, and examine -simultaneously- it's possible antecedents (e.g., positive emotions) and consequences (e.g., academic engagement), as well as its role in objective measures of performance (i.e., GPA). These research efforts could expand the literature on academic PsyCap in the high school context and also contribute to the objective of the positive education, that is, education to achieve both traditional skills and for happiness (Seligman, Ernst, Gillham, Reivich, \& Linkins, 2009).

\section{Academic Engagement}

In previous research, school engagement -the engagement that occurs in a school settinghas typically been defined as a construct that includes behavioral, cognitive, and affective components (Fredricks, Blumenfeld, \& Paris, 2004; Salmela-Aro, 2015). However, recent research in this area demonstrated that school engagement can also be considered an overall concept -called schoolwork or academic engagement- which refers to a positive, fulfilling, study-related state of mind characterized by vigor, dedication, and absorption (Schaufeli, Martinez, Marques-Pinto, Salanova, \& Bakker, 2002). Of these three dimensions, vigor refers to high levels of mental resilience while studying, a willingness to invest effort in one's schoolwork, and a positive approach (Schaufeli et al., 2002). Dedication is characterized by a sense of significance, enthusiasm, pride, identification, and inspiration toward school, in addition to perceiving schoolwork as meaningful (Schaufeli et al., 2002). Absorption is characterized by behavioral accomplishments and flow-like experiences, such as being so fully immersed and 
happily engrossed in one's studying that time passes quickly (Schaufeli et al., 2002). Although it is generally accepted that this approach includes three components, its authors have specified that vigor and dedication make up the core of engagement, whereas absorption could be considered as a consequence of engagement (Schaufeli \& Salanova, 2007).

Previous research conducted in high school populations has shown that this academic engagement approach -which was initially proposed as a work-related construct- is positively associated with self-esteem (Salmela-Aro \& Upadyaya, 2012), self-efficacy (Salmela-Aro \& Upadyaya, 2014), satisfaction with studies (Upadyaya \& Salmela-Aro, 2014), and academic performance (Wang, Chow, Hofkens, \& Salmela-Aro, 2015). In other words, personal resources -such as self-efficacy and self-esteem- foster academic engagement and have positive consequences for students, such as high academic performance and satisfaction. In addition, academic engagement is negatively associated with school burnout, study demands, and depressive symptoms (Salmela-Aro \& Upadyaya, 2014).

Although Schaufeli and colleagues' engagement approach has gained empirical support in school settings (see Salmela-Aro, 2015), little is known about its relationship with other constructs borrowed from the industrial-organizational context, such as academic PsyCap. In other words, the relationship between academic PsyCap and academic engagement has not been investigated. Providing empirical evidence about the relationship between these constructs is of interest because previous research in work settings has demonstrated that PsyCap is an important predictor of longitudinal changes in work engagement (Alessandri, Consiglio, Luthans, \& Borgogni, 2018). This result could indicate -according to the previously mentioned research in school settings (Salmela-Aro \& Upadyaya, 2014; Upadyaya \& Salmela-Aro, 2014; Wang et al., 2015)- that PsyCap (a personal resource) operates as a facilitator of increased work engagement.

\section{Present Study}

The aim of the current study is to examine the indirect relationship between positive emotions and academic performance through sequential mediation by academic PsyCap and academic engagement, respectively. The line of reasoning is the following: When students experience positive emotions more often -according to B\&B theory- they will probably report a 
large number of personal resources (in our case, academic PsyCap), and -according to COR theory- these PsyCap may facilitate students' engagement with their academic tasks, which will probably be translated into better academic performance. In other words, positive emotions will help students to envision goals and challenges and open their minds to productive ways of thinking and problem-solving, thus making them feel more engaged in their studies and, hence, achieve higher academic performance (Pekrun, Goetz, Titz, \& Perry, 2002).

Based on the arguments presented, we have specified and tested a structural equations model (Figure 1) that allows us to test the following hypothesis: Positive emotions are indirectly and sequentially associated with academic performance through academic PsyCap and academic engagement, respectively.

\section{Method}

\section{Participants and Procedures}

The sample comprised 497 (51\% female) Chilean high school students. The students came from 36 classes in three different secondary schools (each of them hosted approximately 500 students). They ranged from 14 to 17 years old $(M=15.71, S D=1.15)$. Of the 497 students, $16.5 \%(n=$ $82)$ were 14 years old, $29.4 \%(n=146)$ were 15 years old, $25.8 \%(n=128)$ were 16 years old, and $28.3 \%(n=140)$ were 17 years old when the data were collected.

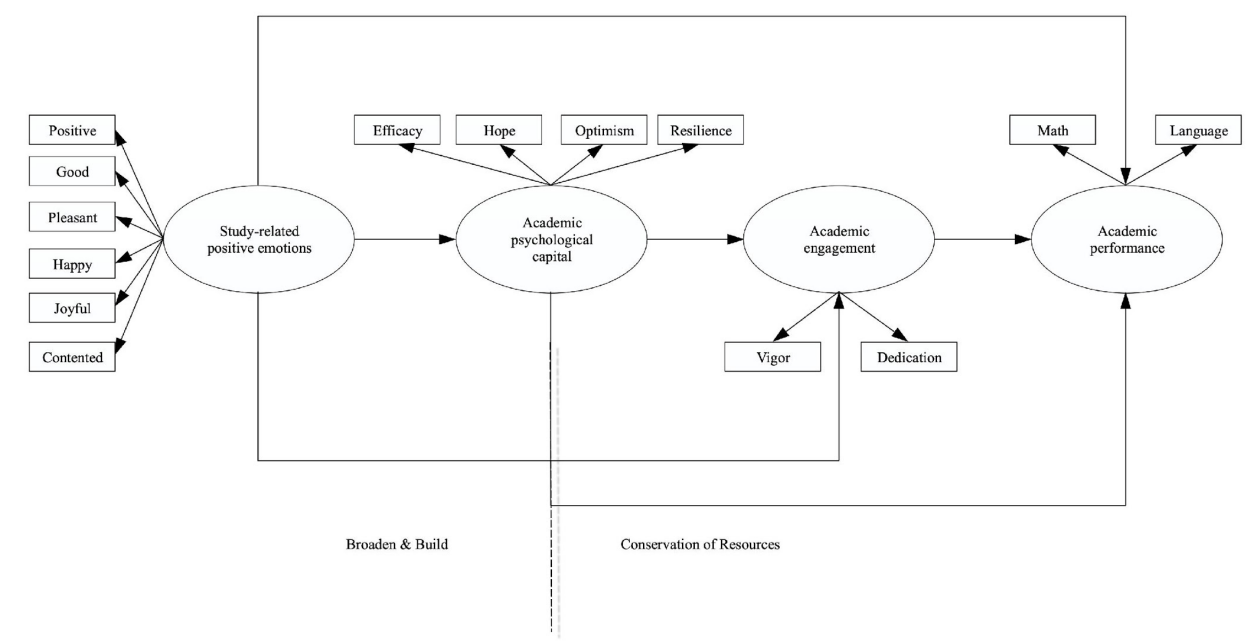

Figure 1. Theory-driven proposed model 
This study was part of a project designed to examine the role of non-intellectual variables in academic performance, and it received approval from the Research Ethics Committee of the host university. The study took place over 5 days in the middle of a regular academic semester, and two trained administrators supervised it. The students who agreed to participate in the study -after school principals and parents gave their permission-were taken to a classroom where a computer was available containing the questionnaire. Participants were encouraged to respond as truthfully as they could, and they received assurance that their responses would be anonymous. They took about 20 minutes to fill out the questionnaire.

\section{Measures}

Positive emotions were measured using the Scale of Positive and Negative Experiences (SPANE; Diener et al., 2010), adapted to the Chilean academic context (Carmona-Halty \& Villegas-Robertson, 2018). This scale includes 12 items that measure positive (six items) and negative (six items) emotional experiences, rated on a scale of 1 (very rarely or never) to 5 (very often or always). For the purposes of this study, only the positive feelings subscale was used, and the scale instructions were adjusted by adding a specific reference to the academic context (e.g., "My studies make me feel happy"). Cronbach's alpha for the overall scale was .92.

Academic PsyCap was measured using the Psychological Capital Questionnaire-12 (PCQ-12; Avey, Avolio, and Luthans, 2011), adapted to the Chilean academic context (Martínez, Meneghel, Carmona-Halty, \& Youssef-Morgan, 2019). The Academic PCQ-12 contains 12 items that measure the four dimensions of the PsyCap construct: (1) efficacy (e.g. "I feel sure when sharing information about my studies with other people"; (2) hope (e.g. "Right now I see myself as being pretty successful in my studies"; (3) optimism (e.g. "Concerning my studies, I'm optimistic about what the future offers me"); and (4) resilience (e.g. "I usually take the stressful aspects of my studies in stride"). Responses were given on a Likert-type scale with scores from 1 (strongly disagree) to 6 (strongly agree). Cronbach's alpha for overall academic PsyCap was .85 .

Academic engagement was measured using the student version of the Utrecht Work Engagement Scale (UWES-9; Schaufeli, Bakker, \& Salanova, 2006), adapted to the Chilean 
context (Carmona-Halty, Schaufeli, \& Salanova, 2019). This scale contained 9 items that measure the three components of the engagement construct: vigor (e.g. "When I get up in the morning, I feel like going to class"); dedication (e.g. "I'm enthusiastic about my studies"); and absorption (e.g., "I get carried away when I am studying"). Participants gave their responses on a Likert-type scale with scores from 0 (never) to 6 (always). In the present study, only the core engagement items were used (i.e., vigor and dedication). Cronbach's alpha for core academic engagement was .83 .

Academic performance was measured as the grade point average (GPA) in two core subjects in the Chilean education program: math and language. The GPA ranged from 1 (poor) to 7 (excellent). The GPA was recorded at the end of the semester, when the data collection took place. Thus, each academic performance indicator covered the period when the questionnaire was administered.

\section{Data Analysis}

First, to test for common method variance bias, we applied Harman's single-factor test. Second, a confirmatory factor analysis (CFA) was specified to test the proposed measurement structure underlying the data. Third, structural equation modelling (SEM) analysis tested the structural relations in the hypothesized model. We used maximum likelihood estimation methods, and we evaluated the goodness-of-fit using chi-square $\left(\chi^{2}\right)$ and normed chi-square $\left(\chi^{2} / d f\right)$, RootMean-Squared Error of Approximation (RMSEA), Comparative Fit Index (CFI), and Standardized Root Mean Residual (SRMR). To help evaluate the cut-off point and ascertain model fit, we followed previous recommendations from the European Journal of Psychological Assessment (Schweizer, 2010). Fourth, to test indirect effects, we implemented the bootstrap procedure with 5000 re-samples, constructing 95\% bias-corrected and accelerated (BCa) confidence intervals (CI).

\section{Results}

Table 1 shows means, standard deviations, skewness, kurtosis, reliability, and the relationship between study variables. Cronbach's alpha was satisfactory for all study variables. However, in order to cross-validate our findings -following Sijtsma (2009)- we also computed 
McDonald's omega reliability index, which produced similar results. Moreover, Harman's single factor test reveals indicators under the recommended fit standards (Table 3, M1). Thus, we concluded that it is unlikely that bias due to common method variance may have affected the study results. In addition, t-tests did not reveal any significant gender, age, or grade differences in the study variables.

\section{Measurement and Structural Model}

The measurement model (M2) consisted of four latent factors and 14 indicators. Specifically, positive emotions had six indicators (i.e., feeling positive, good, pleasant, happy, joyful, and contented); academic PsyCap had four indicators (i.e., efficacy, hope, resilience, and optimism); academic engagement had two indicators (i.e., vigor and dedication); and academic performance had two indicators (i.e., math performance and language performance). The results of the CFA showed an acceptable fit for the measurement model (see Table 3, M2). As Table 2 reveals, the factor loadings were statistically significant at $p<.001$, and they achieved the factorloading criterion of .35 (Byrne, 2010). In addition, factor correlation estimates were statistically significant and in the expected direction.

Table 1

Mean (M), Standard Deviation (SD), Skewness, Kurtosis, reliability indexes, and Correlations for the Study variables

\begin{tabular}{lcccccccccc}
\hline & $\mathrm{M}$ & $\mathrm{SD}$ & $\mathrm{S}$ & $\mathrm{K}$ & $\omega$ & $\alpha$ & 1 & 2 & 3 & 4 \\
\hline 1. Positive emotions & 3.66 & .88 & -.51 & -.19 & .82 & .92 & - & & & \\
2. Academic PsyCap & 3.50 & .70 & -.43 & -.01 & .85 & .85 & $.53^{* *}$ & - & \\
3. Academic engagement & 3.01 & .82 & -.14 & -.29 & .82 & .83 & $.42^{* *}$ & $.59^{* *}$ & - \\
4. Academic performance & 5.83 & .44 & -.24 & -.52 & na & na & $.16^{* *}$ & $.22^{* *}$ & $.17^{* *}$ & - \\
& & & & & & & & & & \\
\hline
\end{tabular}

Note: $* *=p<.001 ; \mathrm{na}=$ not applicable

Considering the acceptable fit of the measurement model (M2), we conducted a SEM analysis to test the hypothesized model. Results showed that the proposed model exceeded the recommended standards and provided a good representation of the sample relations (see Table 3, M3). Figure 2 displays this model with standardized regression weights. The significant direct path coefficients were: 1$)$ from positive emotions to academic PsyCap $(\beta=.63, p<.05), 2)$ from academic PsyCap to academic engagement $(\beta=.76, p<.05)$, and 3$)$ from academic engagement to academic performance $(\beta=.17, p<.05)$. The figure shows the following non-significant direct 
path coefficients: 1) from positive emotions to academic engagement $(\beta=.02, p>.05), 2)$ from academic PsyCap to academic performance $(\beta=.11, p>.05)$, and 3$)$ from positive emotions to academic performance $(\beta=.03, p>.05)$. The proposed model explained significant proportions of variance in academic PsyCap (39\%), academic engagement (56\%), and academic performance $(6 \%)$.

Table 2

Standardized factor loading and correlations from the measurement model

\begin{tabular}{|c|c|c|c|c|}
\hline Indicators & $\begin{array}{c}\text { Factor A } \\
\text { Positive Emotions }\end{array}$ & $\begin{array}{c}\text { Factor B Academic } \\
\text { PsyCap }\end{array}$ & $\begin{array}{l}\text { Factor C Academic } \\
\text { Engagement }\end{array}$ & $\begin{array}{c}\text { Factor D Academic } \\
\text { Performance }\end{array}$ \\
\hline 1-positive & $.79 * *$ & & & \\
\hline 2-good & $.80 * *$ & & & \\
\hline 3-pleasant & $.79 * *$ & & & \\
\hline 4-happy & $.86^{* *}$ & & & \\
\hline 5-joyful & $.83 * *$ & & & \\
\hline 6-contented & $.83 * *$ & & & \\
\hline 7-efficacy & & $.61 * *$ & & \\
\hline 8-hope & & $.79 * *$ & & \\
\hline 9-optimism & & $.60 * *$ & & \\
\hline 10-resilience & & $.71 * *$ & & \\
\hline 11-vigor & & & $.70 * *$ & \\
\hline 12-dedication & & & $.94 * *$ & \\
\hline 13-Math & & & & $.95^{* *}$ \\
\hline 14-Language & & & & $.80 * *$ \\
\hline \multicolumn{5}{|c|}{ Factor correlations } \\
\hline Factor A & - & & & \\
\hline Factor B & $.63 * *$ & - & & \\
\hline Factor C & $.46^{* *}$ & $.74 * *$ & - & \\
\hline Factor D & $.17 * *$ & $.25^{* *}$ & $.27 * *$ & - \\
\hline
\end{tabular}

Note: $* *=p<.001$

\section{Test for Mediation}

The significance of the indirect effect was determined at the level of .05 in this study; the indirect effect was considered statistically significant if the estimates of the $95 \%$ CI did not contain zero. Supporting our hypothesis, we found a significant indirect effect from positive emotions to academic performance via academic PsyCap and academic engagement; $a b=.12, S E$ $=.02, \mathrm{BCa} 95 \% \mathrm{CI}[.08, .18]$. 
Table 3

Results from SEM analysis

\begin{tabular}{lccccccc}
\hline & $\chi^{2}$ & $d f$ & $\chi^{2} / d f$ & CFI & RMSEA & $90 \%$ CI & SRMR \\
\hline M1 Harman's single factor test & 1302.32 & 80 & 16.91 & .68 & .17 & {$[.17, .18]$} & .120 \\
M2 Structural model & 277.45 & 71 & 3.90 & .94 & .07 & {$[.06, .08]$} & .049 \\
M3 Proposed model & 277.45 & 71 & 3.90 & .95 & .07 & {$[.06, .08]$} & .050 \\
& & & & & & & \\
\hline
\end{tabular}

\section{Additional Analysis}

In order to assess the plausibility of an alternative sequence, we tested an additional model (i.e., positive emotions $\rightarrow$ academic engagement $\rightarrow$ academic PsyCap $\rightarrow$ academic performance) because previous research has found reciprocal relations between PsyCap and engagement (Alessandri et al., 2018; Siu et al., 2014). Results did not support this alternative model because the direct effect from PsyCap to academic performance $(\beta=.10, p>.05)$ was not statistically significant.

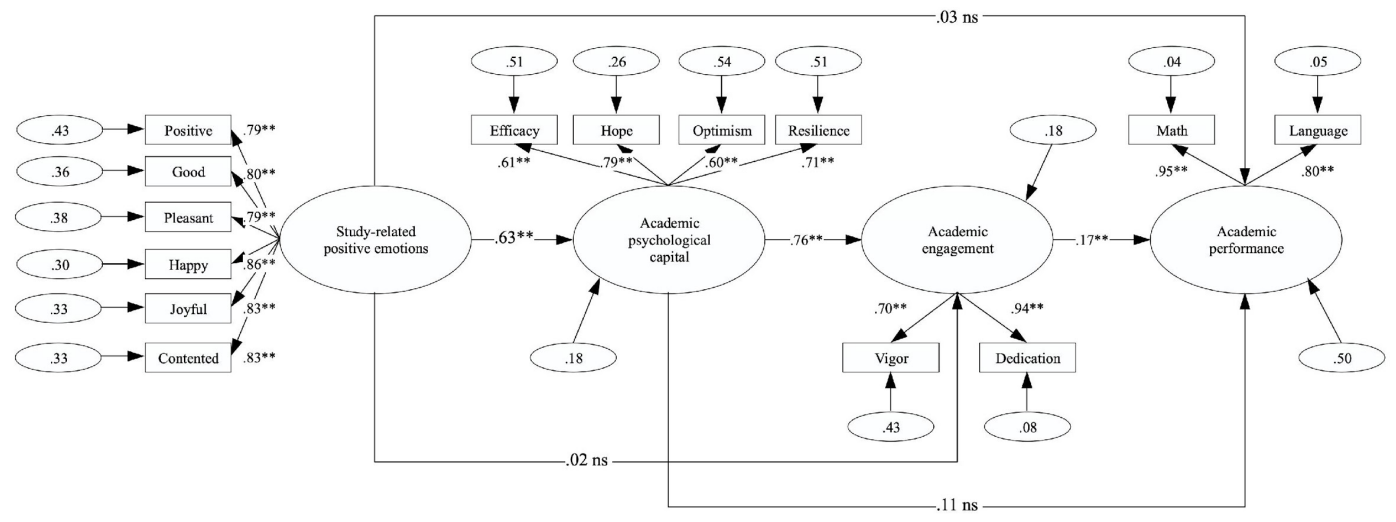

Figure 2. Results for SEM analysis. Numbers next to the arrows represent the standardized direct effects of all latent variables in the model. $* *=p<.001$. Numbers inside de circles represent the estimated error for each variable. ns $=p$ $>.05$.

\section{Discussion}

This study and its findings are relevant in many ways. The theoretical contribution emphasizes the role of PsyCap and engagement in the positive emotions and performance relationships, whereas the practical contribution lies in focusing on the possible ways to increase the study variables through future evidence-based programs. In addition, although some 
limitations must be mentioned, this study's strongest point is that it allows us to propose suggestions for future research. We describe each one next.

\section{Theoretical Contribution}

First, consistent with previous research on the B\&B theory (Fredrikson, 1998), we found that students who more frequently experienced positive emotions related to their studies were more likely to report higher levels of personal resources in the form of PsyCap (Oriol-Granado et al., 2017; Ouweneel et al., 2011; Salanova et al., 2011). In a similar vein, our findings confirmed that the academic PsyCap construct plays a key role in the educational setting. In addition, our results showed that positive emotions could be considered a key variable associated with academic PsyCap.

Second, consistent with previous research on the COR theory (Hobfoll, 2002), we found that students who showed high levels of personal resources (academic PsyCap in our case) were more likely to show positive outcomes (Oriol-Granado et al., 2017; Ouweneel et al., 2011; Salanova et al., 2011). As a positive outcome, we considered academic engagement, which has recently been adapted from the organizational context (Schaufeli et al., 2002) to the school context (Salmela-Aro \& Upadyaya, 2012). Thus, our findings showed that (academic) PsyCap can be considered a relevant personal resource in explaining academic engagement, which is consistent with prior research in the work setting emphasizing the role of PsyCap in work engagement (see Alessandri et al., 2018).

Third, consistent with previous research on academic engagement, the results showed that students who experienced more vigor and dedication in their studies had a greater probability of achieving high academic performance (Salmela-Aro \& Upadyaya, 2012). Furthermore, this result is consistent with extensive research that demonstrated a significant relationship between work engagement and job performance (see Schaufeli, 2017). Thus, academic performance was more effective when students had positive and active attitudes, with affect (dedication) and energy (vigor) in doing their schoolwork.

Fourth, consistent with previous cross-sectional, longitudinal, and experimental research on the hypothesis that happiness precedes and leads to (academic) success (see, Lyubomirsky, 
King, \& Diener, 2005; Walsh, Boehm, \& Lyubomirsky, 2018), we found that students who experienced a higher frequency of positive emotions were more likely -through academic PsyCap and academic engagement- to obtain high academic performance. Thus, the results confirmed our hypothesized model, whereas an alternative model in which the order of the two mediators was switched did not confirm the sequential mediation effect. In addition, given that the introduction of academic PsyCap and academic engagement reduced the direct effect of positive emotions on academic performance to zero, we can conclude that academic PsyCap and academic engagement fully mediated the relationship between positive emotions and academic performance.

Overall, our study's contribution to the research on the association between positive emotions and objective school performance is innovative because it emphasizes the intermediate role of academic PsyCap and engagement.

\section{Practical Implications}

The first practical implication of our study is related to the possible consequences of increasing students' positive emotions. Rather than focusing exclusively on increasing knowledge and academic skills (i.e., academic performance), our results suggest that teachers should also focus on students' feelings. This focus on increasing positive emotions will ultimately -through academic PsyCap and academic engagement- translate into better academic performance. Along these lines, there are several ways teachers can improve the frequency of positive emotions, for example, by encouraging students' capability and giving positive feedback about their effort. Furthermore, teachers can demonstrate involvement (i.e., caring about and showing interest in the student), provide structure (i.e., setting clear rules and following through), and be supportive of autonomy (i.e., allowing students the freedom to make choices and identifying connections between academic work and students' interests). In other words, teachers can support the basic psychological needs of their students (Deci \& Ryan, 2002).

Second, following the logic of our model, directly increasing academic PsyCap and/or academic engagement will also increase academic performance. Previous research has shown the possibility of developing PsyCap, focusing on the promotion of its four components (Luthans, 
Avey, and Patera, 2008; Luthans, Avey, Avolio, and Peterson, 2010). It would be interesting to analyse this possibility in a school context because, to date, there is no previous research in the field. Furthermore, based on the demands-resources model (Bakker \& Demerouti, 2007), it is possible (and desirable) to provide a balance between study resources (e.g. social support) and study demands (e.g., homework overload) as a way to increase academic engagement and decrease academic burnout (see Hodge, Wright, \& Bennett, 2017; Salmela-Aro \& Upadyaya, 2014).

Third, the notion of crossover - the process that operates when a stressor or psychological strain experienced by one person affects the level of strain of another person in the same social environment- could be taken into account in order to provide the transferred emotions, PsyCap, and engagement levels among the students (see Westman, Etzion, \& Chen, 2009; Westman, Shadach, \& Keinan, 2013). For instance, Westman (2001) proposed that crossover mechanisms (i.e., direct, indirect, and spurious) can be applied to both negative and positive experiences and resources. Thus, just as strain in one partner may yield an empathic response in the other, increasing his/her strain, the positive emotions, PsyCap, and engagement in one partner may increase the other partner's engagement (Hobfoll et al., 2018).

\section{Strengths, Weaknesses, and Suggestions for Future Research}

The strong points of the current study are: first, it successfully integrates the B\&B theory and the COR theory, in that positive emotions lead to personal resources (i.e., academic PsyCap), which, in turn, lead to academic well-being (i.e., academic engagement); second, following the logic of our model, we have included an objective measure of performance (i.e., GPA) as a consequence of academic engagement; and third, the GPA was recorded when the semester ended, before the data were collected.

However, there are some weaknesses that have to be acknowledged. First, this crosssectional study did not allow us to establish the causality of the phenomena examined. In fact, for our model -with two mediators- we would need four measurement points, coinciding with the temporal positioning of the constructs involved in the proposed model. Despite this limitation, we proposed a theory-driven model based on recent research with empirical support from cross- 
sectional, longitudinal, and experimental studies (see Walsh et al., 2018). In addition, we tested an alternative model, and the results did not support it. Second, the use of self-report psychological measures may produce common method bias. Therefore, it would be necessary to include different response formats (e.g., Likert scales and faces scales), media (e.g., computer and paper and pencil), and/or locations (e.g., different rooms or sites). However, we used Harman's single factor test and considered some procedural remedies before data collection (see Podsakoff, Mackenzie, Lee, and Podsakoff, 2003). Thus, common method bias is unlikely.

Finally, some avenues for future research can be mentioned. First, based on the substantial role played by interpersonal relationships in students' outcomes and experiences at school, positive emotions could be considered as a consequence of teacher-student relationships (see Cornelius-White, 2007; Roorda, Koomen Split, \& Oort, 2011). Second, based on the crossover model (see Westman et al., 2009; 2013), teachers' own job-related positive emotions, PsyCap, and work engagement could be included in a comprehensive model by examining their role in the components of the proposed model. Third, because our results are consistent with previous research conducted in work settings, it is likely that we are dealing with a general psychological principle that is independent from the specific context. Thus, it would be interesting to examine our model in other settings, such as sports or voluntary work, in order to confirm its applicability. Fourth, these avenues could be examined using quadratic relationships and multilevel analysis in order to improve our knowledge about the relationships among positive emotions, academic PsyCap, academic engagement, and academic performance. 


\section{References}

Alessandri, G., Consiglio, C., Luthans, F., \& Borgogni, L. (2018). Testing a dynamic model of the impact of psychological capital on work engagement and job performance. Career Development International. https://doi.org/10.1108/CDI-11-2016-0210

Avey, J. B., Avolio, B. J., \& Luthans, F. (2011). Experimentally analyzing the impact of leader positivity on follower positivity and performance. The Leader Quarterly, 22, 282-294. https://doi.org/10.1016/j.leaqua.2011.02.004

Avey, J. B., Reichard, R. J., Luthans, F., \& Mhatre, K. H. (2011). Meta-analysis of the impact of positive psychological capital on employee attitudes, behaviors, and performance. Human Resource Development Quarterly, 22(2), 127-152.

https://doi.org/10.1002/hdrq.200070

Bakker, A. B., \& Demerouti, E. (2007). The job demands-resources model: State of the art. Journal of Managerial Psychology, 22(3), 309-328. https://doi.org/10.1108/02683940710733115

Byrne, B. (2010). Structural Equation Modeling with AMOS. Basic Concepts, Applications, and Programming. New York, NY: Routledge.

Carmona-Halty, M., Schaufeli, W. B., \& Salanova, M. (2019). The Utrecht Work Engagement Scale for Students (UWES-9S): Factorial validity, reliability, and measurement invariance in a Chilean sample of undergraduate university students. Frontiers in Psychology. https://doi.or/10.3389/fpsyg.2019.01017

Carmona-Halty, M., \& Villegas-Robertson, J. M. (2018). Scale of Positive and Negative Experience (SPANE): Adaptation and validation in a Chilean school context. Interciencia, 43(5), 317-321.

Carver, C. S. (2003). Pleasure as a sign you can attend to something else: Placing positive feelings within a general model of affect. Cognition and Emotion, 17, 241-261. https://doi.org/10.1080/02699930302294

Cornelius-White, J. (2007). Learner-centered teacher-student relationships are effective: A meta-analysis. Review of Educational Research, 77, 113-143. 
https://doi.org/10.3102/003465430298563

Datu, J. A. D., King, R. B., \& Valdez, J. P. (2016). Psychological capital bolsters motivation, engagement, and achievement: Cross-sectional and longitudinal studies. The Journal of Positive Psychology. https://doi.org/10.1080/17439760.2016.1257056

Datu, J. A. D., \& Valdez, J. P. M. (2016). Psychological capital predicts academic engagement and well-being in Filipino high school students. The Asia-Pacific Education Researcher, 25(3), 399-405. https://doi.org/10.1007/s40299-015-0254-1

Deci, E. L., \& Ryan, R. M. (2002). Handbook of self-determination research. Rochester, NY: The University of Rochester Press.

Diener, E., Wirtz, D., Kim-Prieto, C., Choi, D., Oishi, S., \& Biswas-Diener, R. (2010). New well-being measures: Short scales to assess flourishing and positive and negative feelings. Social Indicators Research, 97(2), 143-156. https://doi.org/10.1007/s11205-009-9493-y

Elliot, A. J., \& Thrash, T. M. (2002). Approach-avoidance motivation in personality: Approach and avoidance temperaments and goals. Journal of Personality and Social Psychology, 82, 804-818. https://doi.org/10.1037/0022-3514.82.5.804

Fredricks, J. A., Blumenfeld, P. C., \& Paris, A. H. (2004). School engagement: Potential of concept, state of the evidence. Review of Educational Research, 74, 59-109. https://doi.org/10.3102/00346543074001059

Fredrikson, B. L. (1998). What good are positive emotions? Review of General Psychology, 2(3), 300-319.

Fredrikson, B. L. (2001). The role of positive emotions in positive psychology: The broadenand-build theory of positive emotions. American Psychologist, 56(3), 218-226.

Fredrikson, B. L. (2013). Positive emotions broaden and build. Advances in Experimental Social Psychology, 47, 1-53. https://doi.org/10.1016/B978-0-12-407236-7.00001-2

Hobfoll, S. E. (1989). Conservation of resources: A new attempt at conceptualizing stress. American Psychologist, 44(3), 513-524. https://doi.org/10.1037/0003-066X.44.3.513

Hobfoll, S. E. (2002). Social and psychological resources and adaptation. Review of General 
Psychology, 6(4), 307-324. https://doi.org/10.1037//1089-2680.6.4.307

Hobfoll, S. E., Halbesleben, J., Neveu, J. P., \& Westman, M. (2018). Conservation of resources in the organizational context: The reality of resources and their consequences. Annual Review of organizational Psychology and Organizational Behavior, 1-26. https://doi.org/10.1146/annurev-orgpsych-032117-104640

Hodge, B., Wright, B., \& Bennett, P. (2017). Increasing students' engagement and reducing exhaustion through the provision of demanding but well-resourced training. Journal of Further and Higher Education. https://doi.org/10.1080/0309877X.2017.1363385

Liao, R., \& Liu, Y. (2015). The impact of structural empowerment and psychological capital on competence among Chinese baccalaureate nursing students: A questionnaire survey. Nurse Education Today. https://doi.org/10.1016/j.nedt.2015.07.003

Linnenbrink-Garcia, L., \& Pekrun, R. (2011). Students' emotions and academic engagement: Introduction to the special issue. Contemporary Educational Psychology, 36, 1-3. https://doi.org/10.1016/j.cedpsych.2010.11.004

Liu, C., Zhao, Y., Tian, X., Zou, G., \& Li, P. (2015). Negative life events and school adjustment among Chinese nursing students: The mediating role of psychological capital. Nurse Education Today, 35(6), 754-759. https://doi.org/10.1016/j.nedt.2015.02.002

Luthans, F., Avey, J. B., Avolio, B. J., \& Peterson, S. (2010). The development and resulting performance impact of positive psychological capital. Human Resources Development Quarterly, 21, 41-66. https://doi.org/10.1002/hrdq.20034

Luthans, F., Avey, J. B., \& Patera, J. L. (2008). Experimental analysis of a web-based training intervention to develop positive psychological capital. Academy of Management Learning \& Education, 7(2), 209-221. https://doi.org/10.5465/AMLE.2008.32712618

Luthans, B. C., Luthans, K. W., \& Jensen, S. M. (2012). The impact of business school students' psychological capital on academic performance. Journal of Education for Business, 87, 253-259. https://doi.org/10.1080/08832323.2011.609844

Luthans, F., \& Youssef-Morgan, C. M. (2017). Psychological capital: An evidence-based positive approach. Annual Review of Organizational Psychology and Organizational 
Behavior. https://doi.org/10.1146/annurev-orgpsych-032516-113324

Luthans, F., Youssef-Morgan, C. M., \& Avolio, B. (2015). Psychological Capital and Beyond. New York: Oxford University Press.

Lyubomirsky, S., King, L, \& Diener, E. (2005). The benefits of frequent positive affect: Does happiness lead to success? Psychological Bulletin, 131(6), 803-855. https://doi.org/10.1037/0033-2909.131.6.803

Martínez, I. M., Meneghel, I., Carmona-Halty, M., \& Youssef-Morgan, C. M. (2019). Adaptation and validation to Spanish of the Psychological Capital Questionnaire 12 (PCQ-12) in academic contexts. Current Psychology. https://doi.org/10.1007/s12144-019-00276-Z

Oriol-Granado, X., Mendoza-Lira, M., Covarrubias-Apablaza, C., \& Molina-López, V. (2017). Positive emotions, autonomy support and academic performance of university students: The mediating role of academic engagement and self-efficacy. Journal of Psychodidactics, 22, 45-53. https://doi.org/10.1387/RevPsicodidact.14280

Ouweneel, E., Le Blanc, P. M., \& Schaufeli, W. B. (2011). Flourishing students: A longitudinal study on positive emotions, personal resources and study engagement. The Journal of Positive Psychology, 6(2), 142-153. https://doi.org/10.1080/17439760.2011.558847

Pekrun, R., Goetz, T., Titz, W., Perry, R. P. (2002). Academic emotions in students's selfregulated learning and achievement: A program of qualitative and quantitative research. Educational Psychologist, 37(2), 91-105. https://doi.org/10.1207/s15326985ep3702_4

Pekrun, R., \& Linnenbrink-García. L. (2012). Academic emotions and student engagement. In S. L. Christenson, A. L. Reschly, \& C. Wylie (Eds.), The handbook of research on student engagement. New York: Springer. https://doi.org/10.1007/978-1-4614-2018-7_12

Podsakoff, P. M., MacKenzie, S. B., Lee, J. Y., \& Podsakoff, N. P. (2003). Common method biases in behavioral research: A critical review of the literature and recommended remedies. Journal of Applied Psychology, 88 (5), 879-903.

https://doi.org/10.1037/0021-9010.88.5.879 
Riolli, L., Savicki, V., \& Richards, J. (2012). Psychological capital buffer to student stress. Psychology, 3(12), 1202-1207. https://doi.org/10.4236/psych.2012.312A178

Roorda, D. L., \& Koomen, M. Y., Split, J. L., Oort, F. J. (2011). The influence of affective teacher-student relationships on students' school engagement and achievement: A meta-analytic approach. Review of Educational Research, 81(4), 493-529. https://doi.org/10.3102/0034654311421793

Salanova, M., Llorens, S., \& Schaufeli, W. B. (2011). "Yes, I can, I feel good, and I just do it!" On gain cycles and spirals of efficacy beliefs, affect and engagement. Applied Psychology: An International Review, 60(2), 255-285. https://doi.org/10.1111/j.1464-0597.2010.00435.x

Salmela-Aro, K. (2015). Toward a new science of academic engagement. Research in Human Development, 12, 304-311. https://doi.org/10.1080/15427609.2015.1068038

Salmela-Aro, K., \& Upadyaya, K. (2012). The schoolwork engagement inventory. European Journal of Psychological Assessment, 28, 60-67. https://doi.org/10.1027/1015-5759/a000091

Salmela-Aro, K., \& Upadyaya, K. (2014). School burnout and engagement in the context of demands-resources model. British Journal of Educational Psychology, 84, 137-151. https://doi.org/10.1111/bjep.12018

Schaufeli, W. B. (2017). Work engagement in Europe: Relations with national economy, governance, and culture. Research Unit Occupational \& Organizational Psychology and Professional Learning (internal report). KU Leuven, Belgium.

Schaufeli, W. B., Bakker, A. B., \& Salanova, M. (2006). The measurement of work engagement with a short questionnaire: A cross-national study. Educational and Psychological Measurement, 66(4), 701-716. https://doi.org/10.1177/0013164405282471

Schaufeli, W. B., Martinez, I. M., Marques-Pinto, A., Salanova, M., \& Bakker, A. (2002). Burnout and engagement in university students: A cross-national study. Journal of Cross-Cultural Psychology, 33(5), 464-481. https://doi.org/10.1177/0022022102033005003 
Schaufeli, W. B., \& Salanova, M. (2007). Work engagement: An emerging psychological concept and its implications for organizations. In S. W. Gilliland, D. D. Steiner, \& D. P. Skarlicki (Eds.), Research in Social Issues in Management (Volume 5): Managing social and ethical issues in organizations. (pp. 135-177). Greenwich, CT: Information Age Publishers.

Schweizer, K. (2010). Some guidelines concerning the modelling of traits and abilities in test construction. European Journal of Psychological Assessment, 26, 1-2. https://doi.org/10.1027/1015-5759/a000001

Sijtsma, K. (2009). On the use, the misuse, and the very limited usefulness of Cronbach's alpha. Psychometrika, 74, 107-120. https://doi.org/10.1007/s11336-008-9101-0

Siu, O. L., Bakker, A. B., \& Jiang, X. (2014). Psychological capital among university students: Relationship with study engagement and intrinsic motivation. Journal of Happiness Studies, 15, 979-994. https://doi.org/10.1007/s10902-013-9459-2

Stiglbauer, B., Gnambs, T. Gamsjäger, M., \& Batinic, B. (2013). The upward spiral of adolescents' positive school experiences and happiness: Investigating reciprocal effects over time. Journal of School Psychology, 51, 231-242.

Upadyaya, K., \& Salmela-Aro, K. (2014). Cross-lagged associations between study and work engagement dimensions during young adulthood. The Journal of Positive Psychology. https://doi.org/10.1080/17439760.2014.983958

Wang, M., Chow, A., Hofkens, T., \& Salmela-Aro, K. (2015). The trajectories of student emotional engagement and school burnout with academic and psychological development: Findings from Finnish adolescents. Learning and Instruction, 36, 57-65. https://doi.org/10.1016/j.learninstruc.2014.11.004

Walsh, L. C., Boehm, J. K., \& Lyubomirsky, S. (2018). Does happiness promote career success? Revisiting the evidence. Journal of Career Assessment, 1-21. https://doi.org/10.1177/1069072717751441

Westman, M. (2001). Stress and strain crossover. Human Relations, 54(6), 717-751. https://doi.org/10.1177/0018726701546002 
Westman, M., Etzion, D., \& Chen, S. (2009). The crossover of positive experiences from business traveler to their spouses. Journal of Managerial Psychology, 24, 269-284. https://doi.org/10.1108/02683940910939340

Westman, M., Shadach, E., Keinan, G. (2013). The crossover of positive and negative emotions: The role of state empathy. International Journal of Stress Management, 20(2), 116133. https://doi.org/10.1037/a0033205 



\title{
Chapter 4
}

\section{Good Relationships, Good Performance: The Mediating Role of Psychological Capital - A Three-wave Study Among Students *}

\begin{abstract}
Academic psychological capital, or PsyCap, -a set of positive psychological resources encompassing hope, efficacy, resilience, and optimism- has begun to gain attention in academia, showing positive relationships with desirable academic outcomes. However, studies in the field have paid limited attention to the social factors that may increase PsyCap and therefore may lead to positive outcomes. In the present study, we examine whether academic PsyCap mediates between teacher-student relationships and academic performance as assessed by student's GPA, using a three-wave longitudinal design. Through structural equation modelling, as expected, a statistically significant indirect effect was found between teacher-student relationships and academic performance via academic PsyCap. Theoretical and practical implications of the results are discussed; strengths and weaknesses are mentioned; and future research directions are proposed.
\end{abstract}

Keywords teacher-student relationships; academic PsyCap; academic performance

\author{
Marcos Carmona-Halty ${ }^{1}$ \\ Wilmar B. Schaufeli ${ }^{2,3}$ \\ Marisa Salanova ${ }^{4}$ \\ ${ }^{1}$ Escuela de Psicología y Filosofía, Universidad de Tarapacá, Arica, Chile \\ ${ }^{2}$ Research Unit Occupational \& Organizational Psychology and Professional Learning, KU \\ Leuven, Louvain, Belgium \\ ${ }^{3}$ Department of Psychology, Utrecht University, Utrecht, The Netherlands \\ ${ }^{4}$ WANT Research Team, Universitat Jaume I, Castellón de la Plana, Spain
}

* Carmona-Halty, M., Schaufeli, W. B., \& Salanova, M. (2019). Good relationships, good performance: The mediating role of psychological capital - A three-wave study among students. Frontiers in Psychology. 10:306. https://doi.org/10.3389/fpsyg.2019.00306 


\section{Introduction}

Despite previous studies showing positive relationships between academic PsyCap and desirable academic outcomes (e.g., academic adjustment: Liran \& Miller, 2017; academic engagement: Siu, Bakker, \& Jiang, 2014; satisfaction with life: Riolli, Savicki, \& Richards, 2012; and academic performance: Luthans, Luthans, \& Jensen, 2012), there are no previous studies of the social factors that might play a role in sparking this positive relationship. This is an important limitation because -based on Goldstein (1999)-academic settings are considered a relational zone in which the quality of the interactions promotes students' motivation, wellbeing, and performance (Furrer \& Skinner, 2003). Thus, providing empirical evidence about the interaction between teacher-student relationships (TSR), academic PsyCap, and academic performance (AP) could be an important step in understanding the role of social factors in building students' PsyCap, and in developing future evidence-based interventions programs to foster students' PsyCap, wellbeing, and performance.

Self-determination theory (SDT) recognizes the importance of feeling connected to others as a basic psychological need (the so-called need for relatedness) and is considered a fundamental ingredient for functioning at optimal levels (Ryan \& Deci, 2000; 2017). Hence, a student who perceives an emotional connection with his/her social environment, believes that $\mathrm{s} / \mathrm{he}$ is cared for and loved, and feels special to his/her key social partners (e.g., teacher-student relationships) has satisfied his/her need for relatedness. Along this line, previous research has demonstrated the relevant role that interpersonal relationships play in students' success in terms of engagement, achievement, and wellbeing (Cornelius-White, 2007; Datu, 2017; Furrer \& Skinner, 2002; King, 2015; Roorda, Koomen, Spilt, \& Oort, 2011). The explanation is that highquality relationships with significant others provide students with the necessary emotional security to actively explore and effectively deal with their (academic) world (Martin \& Dowson, 2009).

The conservation of resources (COR) theory recognizes the importance of accumulating resources in the biological, cognitive, and social domains as a strategy to preserve and foster their health and wellbeing, the so-called resource caravan (Hobfoll, 1989; 2002; 2011; Hobfoll, 
Halbesleben, Neveu, \& Westman, 2018). Thus, a student who accumulates personal resources (e.g., hope, efficacy, resilience, and optimism) is more likely to possess the specific skills and attitudes necessary to meet academic requirements and, therefore, achieve academic success. In line with this reasoning, previous research has identified academic PsyCap as a predictor of academic performance (Carmona-Halty, Salanova, Llorens, \& Schaufeli, 2019; Datu, King, \& Valdez, 2016; Luthans, Luthans, \& Jensen, 2012; Ortega-Maldonado \& Salanova, 2017). The explanation is that academic PsyCap facilitates the processes necessary for students' attention, interpretation, and retention of positive and constructive memories that are conducive to wellbeing and good performance (Luthans \& Youssef-Morgan, 2017).

Overall, the proposed mediational model assumes that students with high-quality TSR will be in a better position to persevere in their objectives (i.e., have hope), rely on their own abilities (i.e., be efficacious), overcome obstacles (i.e., be resilient), and be optimistic about their future (i.e., feel optimism); in turn, these set of four resources would foster AP. In other words, when students satisfy their need for relatedness, they are more likely to accumulate personal resources in the form of PsyCap that can help them to achieve good academic performance. Hence, we tested a structural equation model that assumes that Academic PsyCap mediates between TSR and AP.

\section{Materials and Methods}

\section{Participants}

The sample consisted of 771 high school students attending different Chilean educational institutions. Participants ranged in age from 12 to 18 years $(M=14.25, \mathrm{SD}=1.60)$, and $51 \%$ of the sample was female. Of the 771 students, $18 \%$ were 12 years old, $18 \%$ were 13 years old, $19 \%$ were 14 years old, $21 \%$ were 15 years old, $14 \%$ were 16 years old, $7 \%$ were 17 years old, and $2 \%$ were 18 years old at the time of data collection.

\section{Procedure}

This study was part of a project designed to examine the role of non-intellectual variables in academic performance. The school principals, the students, and the students' parents granted a 
written informed consent. The adolescents voluntarily completed a questionnaire twice: once at the end of the regular academic semester (Time 1: TSR) and once nine weeks later (Time 2: academic PsyCap). In addition, AP was assessed at the end of the next academic semester, nine weeks later (Time 3: AP). The online data collection was carried out in a group session of about 25 students, and we used the Spanish version of the scales because it is the official language. This study was carried out in accordance with the recommendations of Comité Ético y Científico (CEC-UTA) with written informed consent from all subjects in accordance with the Declaration of Helsinki.

\section{Instruments}

At time 1, TSR was measured using the Teacher-Student Relationships Scale (Martin, Marsh, McInerney, Green, \& Dowson, 2007). This scale has 4 items (e.g., "My teachers give me the help and support I need) rated on a scale from 1 (strongly disagree) to 7 (strongly agree). At time 2, Academic PsyCap was measured using an adaptation of the Psychological Capital Questionnaire (Avey, Avolio \& Luthans, 2011) to the academic context. This questionnaire has 12 items (e.g. "Right now I see myself as being pretty successful in my studies") rated on a scale from 1 (strongly disagree) to 6 (strongly agree). At time 3, AP was assessed using the grade point average (GPA) provided by the educational institutions. The GPA was based on three mandatory subjects in the Chilean education curriculum: math, language, and history. According to the Chilean grading system, GPAs range from 1 (poor) to 7 (excellent). The three subjects are offered in both semesters (March-June and July-November), with a total of six hours per week. For the objective of this study, the GPA was included of the end of the semester before the data collection.

\section{Data Analysis}

All data analyses were conducted using JASP 0.9.01 and SPSS AMOS 23. We used maximum likelihood estimation methods, and goodness-of-fit was evaluated using absolute and relative indexes: chi-square $\left(\chi^{2}\right)$ and normed $\chi^{2}$, Incremental Fit Index (IFI), Comparative Fit Index (CFI), Root-Mean-Squared Error of Approximation (RMSEA) with a confidence interval (90\%), and Standardized Root Mean Residual (SRMR). To determine the fit of the model, we followed the European Journal of Psychological Assessment (Schweizer, 2010) and previous 
recommendations (Schreiber, Nora, Stage, Barlow, \& King, 2006). Finally, we tested the statistical significance of the indirect effects by computing the bias-corrected and accelerated method (BCa) around the indirect effect, as obtained from bootstrapping analysis (Williams \& MacKinnon, 2008).

\section{Results}

Table 1 shows means, standard deviations, Cronbach's alpha and McDonald's omega indexes, and Pearson's correlations among the variables. The internal consistencies obtained for the scales used were good, and the pattern of correlations revealed significant direct relationships for all the measures in our sample.

Table 1

Means (M), standard deviation (SD), alpha and omega indexes, and correlations for the study variables

\begin{tabular}{lccccccc}
\hline & M & SD & $\alpha$ & $\omega$ & 1 & 2 & 3 \\
\hline 1. Teacher-student relationship (T1) & 5.34 & 1.39 & .893 & .895 & - & & \\
2. Academic PsyCap (T2) & 4.06 & 1.00 & .915 & .916 & $.382^{* *}$ & & - \\
3. Academic Performance (T3) & 5.31 & .76 & .777 & .780 & $.162^{* *}$ & $.281^{* *}$ & - \\
\hline
\end{tabular}

Note: $* * p<.001$.

The hypothesized model consisted of 7 latent factors and 19 indicators. That is, the latent TSR one factor reflects TSR with four indicators; academic PsyCap is composed of one-high order factor and four lower-order factors, which, in turn, are formed by 12 indicators; and three indicators make up the latent AP factor. Results showed that this model exceeded the recommended standards and was a good representation of the sample relations, explaining $17.5 \%$ of the academic PsyCap variance and $9.8 \%$ of the AP variance: $\chi^{2}=694.289 ; \chi^{2} / d f(145)=4.788$; $\mathrm{IFI}=.929 ; \mathrm{CFI}=.929 ; \mathrm{RMSEA}=.070,90 \% \mathrm{CI}[.065, .075] ; \mathrm{SRMR}=.053 . \mathrm{In}$ addition, as figure 1 shows, the factor loadings were uniformly moderate to high and statistically significant and exceeded the factor-loading criterion of .35 by far (Byrne, 2010).

For the mediation analysis, we implemented a bootstrapping procedure with 5000 new samples taken from our sample, and indirect effects were calculated (Hayes, 2009). The results led us to conclude that: 1$)$ TSR is significantly related to academic PsyCap $(a=.418, \mathrm{SE}=.039$, BCa 95\% CI $[.339, .492], \mathrm{p}<.001) ; 2$ ) academic PsyCap is significantly related to AP after controlling for TSR $(b=.295, \mathrm{SE}=.063, \mathrm{BCa} 95 \% \mathrm{CI}[.158, .403], \mathrm{p}<.001)$; and 3$)$ the indirect 
effect between TSR and AP -via academic PsyCap- is statistically significant $(a b=.123, \mathrm{SE}=$ $.031, \mathrm{BCa} 95 \% \mathrm{CI}[.066, .186], \mathrm{p}<.001)$. In addition, TSR is not significantly related to AP $(c=$ $.039, \mathrm{SE}=.066, \mathrm{BCa} 95 \% \mathrm{CI}[-.082, .177], \mathrm{p}>.050)$. Hence, we can conclude that academic PsyCap fully mediates the relationship between TSR and AP.

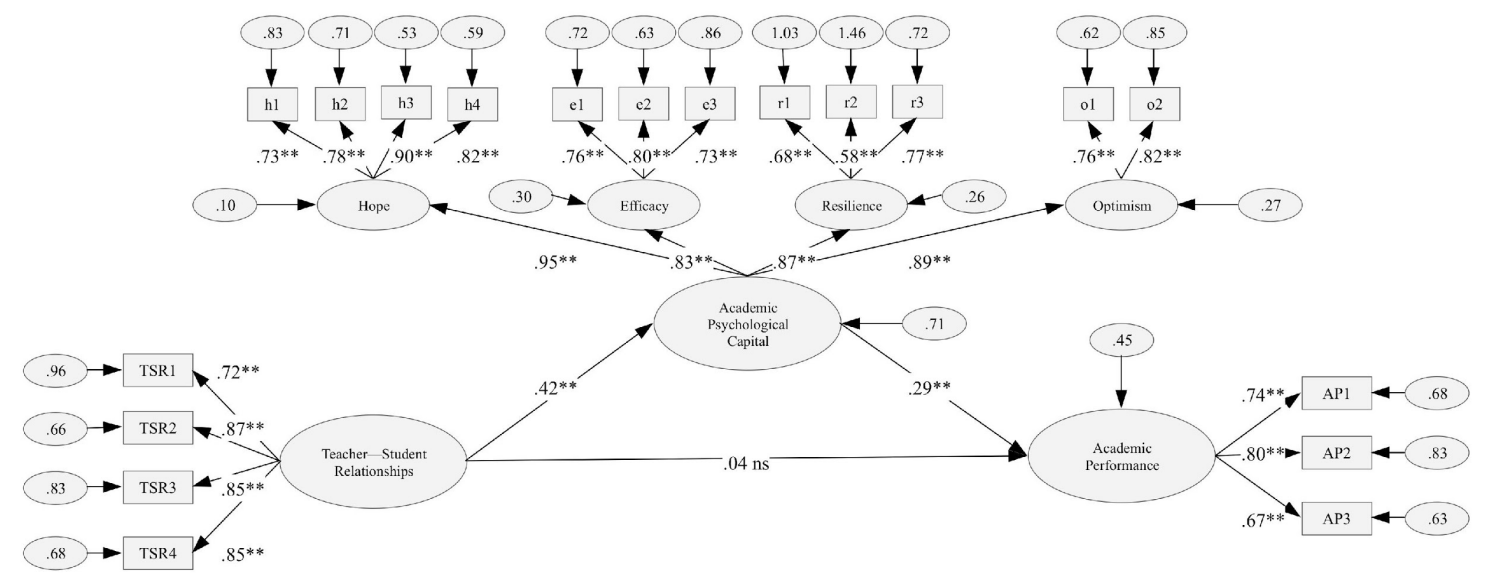

Figure 1

Single mediation model shows the effect of teacher-student relationships on academic performance through academic psychological capital. Standardized coefficients are presented. $* *=p<.001$; ns $=$ non-significant effect.

\section{Discussion}

The present study makes an innovative contribution to the scarce research on the antecedents of academic PsyCap (i.e., a set of resources composed of hope, efficacy, resilience, and optimism) and the interactions among TSR, academic PsyCap, and AP.

Consistent with previous research on SDT -particularly studies on the need for relatedness- we found that students who perceive high-quality relationships with their teachers are more likely to report higher levels of academic PsyCap. In a similar vein, our findings confirmed -in agreement with COR theory- that students who have high levels of academic PsyCap are more likely to achieve better academic performance. Taken together, integrating both SDT and COR theories, we hypothesized and confirmed that academic PsyCap is a mediator between TSR and AP. In other words, we found that the path from good relationships to good performance is fully mediated by academic PsyCap.

The practical implications of the current study are: first, rather than focusing exclusively on increasing academic knowledge and skills, teachers should also focus on the affective elements 
of high-quality relationships with their students; that is, getting along with them, caring about them and showing interest, and providing help and support, among others. According to our results, this focus will help -through increased academic PsyCap- to achieve better academic performance. Second, PsyCap interventions (PCI) have been carried out by increasing its four components using a within-individual approach (see Luthans, Avey \& Patera, 2008; Luthans, Avey, Avolio \& Peterson, 2010). However, our results suggest that it might be necessary to include the teachers in an academic PCI as well in order to develop his/her social skills and stimulate developing a high-quality relationships with students. Thus, a between-individual approach could be an important step in future of PCI programs.

The strengths of the current study are: first, we used a longitudinal approach, which is scarce in academic PsyCap research; second, we included an objective measure of performance (i.e. GPA); and third, we successfully integrated STD and COR theories in an academic setting. However, there are also some weaknesses that have to be acknowledged. First, to assess TSR and academic PsyCap, we used students' self-reports. In future research, we could include teachers' reports about the students' TSR and their perceptions of their' PsyCap. Second, only unidirectional effects were examined (i.e., TSR $\rightarrow$ academic PsyCap $\rightarrow$ AP). In future research, bi-directional effects using cross-lagged models could be included. Third, only adolescent high school students were recruited. In future research, we could include different academic levels (e.g., undergraduate university students).

Finally, some avenues for future research can be mentioned. First, based on Furrer and Skinner (2002), parent-child and peer-student relationships could be incorporated in our model in order to obtain a better understanding of the role of significant others in academic PsyCap. Second, based on broaden-and-build theory (Fredrikson, 1998), the mediator role of studyrelated positive emotions between teacher-student relationships and academic PsyCap could be considered. Third, based on Ryan and Deci (2000), basic need satisfaction could be explored as an antecedent of academic PsyCap. 


\section{References}

Avey, J. B. (2014). The left side of Psychological Capital: New evidence on the antecedents of PsyCap. Journal of Leadership \& Organizational Studies, 21(2), 141-149. https://doi.org/10.1177/1548051813515516

Avey, J. B., Avolio, B. J., \& Luthans, F. (2011). Experimentally analysing the impact of leader positivity on follower positivity and performance. The Leadership Quarterly, 22, 282294. https://doi.org/10.1016/j.leaqua.2011.02.004

Byrne, B. (2010). Structural Equation Modelling with AMOS. Basic Concepts, Applications, and Programming. New York, NY: Routledge.

Carmona-Halty, M., Salanova, M., Llorens, S., \& Schaufeli, W. B. (2018). How psychological capital mediates between study-related positive emotions and academic performance. Journal of Happiness Studies. https://doi.org/10.1007/s10902-018-9963-5

Cornelius-White, J. (2007). Learner-entered teacher-student relationships are effective: A meta-analysis. Review of Educational Research, 77, 113-143.

https://doi.org/10.3102/003465430298563

Datu, J. A. D. (2017). Sense of relatedness is linked to higher grit in a collectivist setting. Personality and Individual Differences, 105, 135-138. https://doi.org/10.1016/j.paid.2016.09.039

Datu, J. A. D., King, R. B., \& Valdez, J. P. M. (2016). Psychological capital bolsters motivation, engagement, and achievement: Cross-sectional and longitudinal studies. Journal of Positive Psychology. https://doi.org/10.1080/17439760.2016.1257056

Fredrikson, B. L. (1998). What good are positive emotions? Review of General Psychology, 2(3), 300-319. https://doi.org/10.1037/1089-2680.2.3.300

Furrer, C., \& Skinner, E. (2003). Sense of relatedness as a factor in children's academic engagement and performance. Journal of Educational Psychology, 95, 148-162. https://doi.org/10.1037/0022-0663.95.1.148

Hayes, A. F. (2009). Beyond baron and Kenny: Statistical mediation analysis in the new millennium. Communication Monographs, 76(4), 408-420. 
https://doi.org/10.1080/03637750903310360

Hobfoll, S. E. (1989). Conservation of resources: A new attempt at conceptualizing stress. American Psychologist, 44, 513-524. https://doi.org/10.1037/0003-066X.44.3.513

Hobfoll, S. E. (2002). Social and psychological resources and adaptation. Review of General Psychology, 6(4), 307-324. https://doi.org/10.1037//1089-2680.6.4.307

Hobfoll, S. E. (2011). Conservation of resource caravans and engaged settings. Journal of Occupational and Organizational Psychology, 84, 116-122. https://doi.org/10.1111/j.2044-8325.2010.02016.x

Hobfoll, S. E., Halbesleben, J., Neveu, J. P., \& Westman, M. (2018). Conservation of resources in the organizational context: The reality of resources and their consequences. Annual Review of organizational Psychology and Organizational Behaviour, 5(10), 1-10.26. https://doi.org/10.1146/annurev-orgpsych-032117-104640

King, R. B. (2015). Sense of relatedness boosts engagement, achievement, and well-being: A latent growth model study. Contemporary Educational Psychology, 42, 26-38. https://doi.org/10.1016/j.cedpsych.2015.04.002

Liran, B. H., \& Miller, P. (2017). The role of psychological capital in academic adjustment among university students. Journal of Happiness Studies. https://doi.org/10.1007/s10902-017-9933-3

Luthans, F., Avey, J. B., Avolio, B. J., \& Peterson, S. (2010). The development and resulting performance impact of positive psychological capital. Human Resources Development Quarterly, 21, 41-66. https://doi.org/10.1002/hrdq.200034.

Luthans, F., Avey, J. B., \& Patera, J. L. (2008). Experimental analysis of a web-based training intervention to develop positive psychological capital. Academy of Management Learning \& Education, 7(2), 209-221. https://doi.org/10.5465/AMLE.2008.32712618

Luthans, B. C., Luthans, K. W., \& Jensen, S. M. (2012). The impact of business school students' psychological capital on academic performance. Journal of Education for Business, 87, 253-259. https://doi.org/10.1080/08832323.2011.609844 
Luthans, F., \& Youssef-Morgan, C. M. (2017). Psychological capital: An evidence-based positive approach. Annual Review of Organizational Psychology and Organizational Behaviour. https://doi.org/10.1146/annurev-orgpsych-032516-113324

Martin, A. J., \& Dowson, M. (2009). Interpersonal relationships, motivation, engagement, and achievement: Yields for theory, current issues, and educational practice. Review of Educational Research. 79, 327-365. https://doi.org/10.3102/0034654308325583

Martin, A. J., Marsh, H. W., McInerney, D. M., Green, J., \& Dowson, M. (2007). Getting along with teachers and parents: The yields of good relationships for students' achievement motivation and self-esteem. Australian Journal of Guidance \& Counselling, 17(2), 109-125. https://doi.org/10.1375/ajgc.17.2.109

Ortega-Maldonado, A., \& Salanova, M. (2017). Psychological capital and performance among undergraduate students: The role of meaning-focused coping and satisfaction. Teaching in Higher Education. https://doi.org/10.1080/13562517.2017.1391199

Riolli, L., Savicki, V., \& Richards, J. (2012). Psychological capital as a buffer to student stress. Psychology, 3(12A), 1202-1207. https://doi.org/10.4236/psych.2012.312A178

Roorda, D. L., \& Koomen, M. Y., Split, J. L., Oort, F. J. (2011). The influence of affective teacher-student relationships on students' school engagement and achievement: A meta-analytic approach. Review of Educational Research, 81(4), 493-529. https://doi.org/10.3102/0034654311421793

Ryan, R. M., \& Deci, E. L. (2000). Self-determination theory and the facilitation of intrinsic motivation, social development, and well-being. American Psychologist, 55, 68-78. https://doi.org/10.1037/0003-066X.55.1.68

Ryan, R. M., \& Deci, E. L. (2017). School as contexts for learning and social development. In R. M. Ryan, \& E. L. Deci, Self-Determination Theory: Basic Psychological Needs in Motivation, development, and Wellness (pp. 351-381). London: The Guilford Press.

Schweizer, K. (2010). Some guidelines concerning the modelling of traits and abilities in test construction. European Journal of Psychological Assessment, 26, 1-2. https://doi.org/10.1027/1015-5759/a000001 
Schreiber, J. B., Nora, A., Stage, F. K. Barlow, E., \& King, J. (2006). Reporting structural equation modelling and confirmatory factor analysis results: A review. The Journal of Educational research, 99(6), 323-338. https://doi.org/10.3200/JOER.99.6.323-338

Seligman, M. E. P., Ernst, R. E., Gillham, J., Reivich, K., \& Linkins, M. (2009). Positive education: Positive psychology and classroom interventions. Oxford Review of Education, 35(3), 293-311. https://doi.org/10.1080/03054980902934563

Siu, O. L., Bakker, A. B., \& Jiang, X. (2014). Psychological capital among university students: Relationships with study engagement and intrinsic motivation. Journal of Happiness Studies, 15, 979-994. https://doi.org/10.1007\%s10902-013-9459-2

Williams, J., \& MacKinnon, D. P. (2008). Resampling and distributions of the product methods for testing indirect effects in complex models. Structural Equation Modelling, 15, 2351. https://doi.org/10.1080/10705510701758166

You J. W. (2016). The relationship among college student's psychological capital, learning empowerment, and engagement. Learning and Individual Differences, 49, 17-24. https://dio.org/10.1016/j.lindif.2016.05.001 



\title{
Chapter 5 \\ The Strengthening Starts at Home: Parent-child Relationships, Psychological Capital, and Academic Performance - A Longitudinal Mediation Analysis *
}

\begin{abstract}
This longitudinal study examines how academic psychological capital mediates between parent-child relationships and academic performance in a group of high school students. The sample consisted of 402 students ( 217 girls and 187 boys) aged between 12 and 17 years. Using a three-wave design, as hypothesized, a significant indirect effect was found between (good) parent-child relationships (assessed at time 1) and academic performance (assessed at time 3) via academic psychological capital (assessed at time 2). Students who perceived high-quality relationships with their parents reported high levels of academic psychological capital and obtained better objective academic performance over time. Theoretical and practical implications of the results are discussed, as well as strengths and weaknesses and future research directions.
\end{abstract}

Keywords parent-child relationships; psychological capital; academic performance

\author{
Marcos Carmona-Halty ${ }^{1}$ \\ Marisa Salanova ${ }^{2}$ \\ Wilmar B. Schaufeli ${ }^{3,4}$ \\ ${ }^{1}$ Escuela de Psicología y Filosofía, Universidad de Tarapacá, Arica, Chile \\ ${ }^{2}$ WANT Research Team, Universitat Jaume I, Castellón de la Plana, Spain \\ ${ }^{3}$ Research Unit Occupational \& Organizational Psychology and Professional Learning, KU \\ Leuven, Louvain, Belgium \\ ${ }^{4}$ Department of Psychology, Utrecht University, Utrecht, The Netherlands
}

\footnotetext{
* Carmona-Halty, M., Salanova, M., \& Schaufeli, W. B. (2020). The strengthening starts at home: Parent-child relationships, psychological capital, and academic performance - a longitudinal mediation analysis. Current Psychology. https://doi.org/10.1007/s12144-02000898-8
} 


\section{Introduction}

In the context of positive education -education for both traditional skills and happiness (Seligman, Ernst, Gillham, Reivich, \& Linkins, 2009)- the psychological capital (PsyCap) construct has received increasing attention in the educational research agenda (Luthans, Luthans, \& Jensen, 2012). However, previous studies have often focused on the prediction of academic (self-reported) outcomes, rather than their possible antecedents (e.g., Datu, King, \& Valdez, 2016; Siu, Bakker, \& Jiang, 2014). Hence, to date, no studies have examined how family factors can lead to the development of PsyCap and its later role in producing objective academic outcomes (i.e., Grade Point Average, GPA). However, it is well-established that: 1) academic functioning does not depend exclusively on the student's characteristics or academic environment (DeBerard, Spielman, \& Julka, 2003; Richardson, Abraham, \& Bond, 2012); and 2) family factors play a relevant role in the student's academic functioning (Bergin \& Bergin, 2009; Martin, Marsh, McInerney, Green, \& Dowson, 2007). Therefore, the aim of the present study is to fill this gap by examining how academic PsyCap mediates between parent-child relationships and academic performance over time. Providing empirical evidence about the relationships among these variables can help to expand our knowledge about possible ways to improve academic PsyCap through evidence-based interventions, with family members as a relevant actor in this process.

\section{Parent-Child Relationships}

Getting along with significant others is an important social predictor of students' desirable academic outcomes (Furrer \& Skinner, 2002; Roorda, Koomen, Split, \& Oort, 2011). This is supported by different theories that acknowledge the relevance of high-quality relationships in young people's lives (for a theoretical review, see Martin \& Dowson, 2009). For example, self-determination theory (Ryan \& Deci, 2000) describes how the satisfaction of the need for relatedness (and other basic needs) influences students' motivation (e.g., Sulea, van Beek, Sarbescu, Virga, \& Schaufeli, 2015). Likewise, attachment theory (Bowlby, 1969) emphasizes that a history of secure attachment enhances adequate functioning in different life domains, including the school setting (e.g., Cutrona, Cole, Colangelo, Assouline, \& Russel, 1994). Additionally, social cognitive theory describes how significant others -via problem- 
solving modelling and supportive communication- play an important role in building students' self-efficacy (Bandura, 1997). Together, these theories suggest that if a child experiences an emotional connection with his/her social environment, believes that $\mathrm{s} /$ he is cared for and loved, and feels special to his/her key social partners, it is likely that s/he will function properly in the academic context and perform accordingly.

Parents are significant others who represent young people's most important social relationships (Furrer \& Skinner, 2002). In accordance with the theories described above, previous studies found that the better the relationship between parents and their children, the better the children perform (Bergin \& Bergin, 2009; Elmore \& Huebner, 2010; Fan, 2001). More specifically, a good relationship between parents and children -in terms of secure attachment, social support, and/or caring relationships- is related to academic engagement (Furrer \& Skinner, 2002), self-esteem (Martin et al., 2007), academic motivation (Guay, Marsh, Senécal, \& Dowson, 2008), positive emotions (Ahmed, Minnaert, van der Werf, \& Kuyper, 2010), school satisfaction (Elmore \& Huebner, 2010), subjective well-being (King, 2015), passion and perseverance (Datu, 2017), school adjustment and readiness (Anderson, 2018; Huang, Yu, \& Wu, 2018), learning motivation (Cheng, Kong, Gao, \& Mo, 2018), and academic achievement (Toor, 2018). The explanation for this is that parents -through a good relationship with their children- (can) satisfy basic needs for acceptance, belonging, thus providing their children with emotional security that allows them to explore their environment and deal with their academic demands (Martin \& Dowson, 2009). Finally, we also expect that positive parent relationships will foster better feelings of positive psychological resources to children such as feeling more hopeful, efficacious, resilient, and optimistic in their school environment.

\section{Academic PsyCap}

According to Hobfoll's (2002) notion of resource caravans - psychological resources that may "travel together" and interact synergistically to produce differentiated manifestations over time and across different contexts- PsyCap defined as an individual's positive psychological state of development, characterized by hope, efficacy, resilience, and optimism (Luthans, YoussefMorgan, \& Avolio, 2015). Although it was initially proposed as a work-related construct, more 
recently the notion of academic PsyCap has been used in a growing number of studies (e.g. Datu et al., 2016; Luthans et al., 2012; Siu et al., 2014). The reasoning is that, psychologically speaking, the activities students perform can also be considered "work", defined as goal-directed and structured activities that are compulsory in nature (Schaufeli, Martínez, Marques-Pinto, Salanova, \& Bakker, 2002). More specifically, academic PsyCap describes students who persevere in the fulfilment of their objectives and have the ability to reorient their previous strategies in order to achieve their proposed goals (i.e., have hope); rely on their own abilities and strive to obtain favourable results (i.e., are efficacious); overcome problematic situations and are able to recover from adversity in order to achieve success in their activities (i.e., are resilient); and make positive attributions about their experiences and are optimistic about their future (i.e., feel optimism).

Initial research with undergraduate university students found positive relationships between academic PsyCap on the one hand, and engagement, motivation, and achievement on the other (Luthans et al., 2012; Siu et al., 2014; Vanno, Kaemkate, \& Wongwanich, 2014). More recently, similar evidence was found among high school students, showing significant associations between academic PsyCap and wellbeing, flourishing, and positive affect (Datu \& Valdez, 2016), learning empowerment (You, 2016), competence (Liao \& Liu, 2016), coping and satisfaction (Ortega-Maldonado \& Salanova, 2018), academic adjustment (Liran \& Miller, 2017), academic performance (Carmona-Halty, Salanova, Llorens, \& Schaufeli, 2019a), and school belongingness (Datu \& Valdez, 2019). The explanation is that the academic PsyCap components share a common mechanism of "positive appraisal of circumstances and probability for success based on motivated effort and perseverance" (Luthans, Avolio, Avey, \& Norman, 2007, p. 550), resulting in a sense of control, intentionality, and agentic goal pursuit (Luthans \& YoussefMorgan, 2017).

\section{Parent-Child Relationships, Academic PsyCap, and Academic Performance}

Previous research has shown mixed evidence, with significant and non-significant effects, regarding the relationship between family factors and academic performance (Alnabhan, Al-Zegoul, \& Harwell, 2001; Román, Cuestas, \& Fenollar, 2008). Some authors suggest that 
mediator variables might explain the association between these two variables (Cheng, Ickes, \& Verhofstadt, 2012). Following this lead, we propose that academic PsyCap mediates between parent-child relationships -as an indicator that students perceive help, support, care, and interest from their parents- and academic performance (assessed as GPA scores). This expectation is supported, on the one hand, by research that has demonstrated parents' relevance in the prediction of different academic outcomes (Datu, 2017; Guay et al., 2008; Martin et al., 2007) and, on the other hand, by research that identifies academic PsyCap as a predictor of academic performance (Carmona-Halty et al., 2019a; Carmona-Halty, Salanova, Llorens, \& Schaufeli, 2019b; Datu et al., 2016; Ortega-Maldonado \& Salanova, 2018). More specifically, when parents have highquality relationships with their children -based on Cutrona et al. (1994)- they are (also) providing a safety net that allows them to actively explore their environment. This safety net puts them in a better position to persevere in pursuing their achieving academic goals (i.e., hope), make the necessary effort to complete their academic tasks (i.e., efficacy), successfully overcome adversity and problems that arise (i.e., resilience), and make positive attributions about succeeding (i.e., optimism). In addition, based on COR theory, the accumulation of personal resources in the form of academic PsyCap will help children to achieve better academic performance. In other words, parents who support their children are laying the foundation for accumulating PsyCap in their children and hence to perform adequately at school.

Based on the reasoning above, we specified and tested a structural equation model that assumes that academic PsyCap mediates between the quality of parent-child relationships and academic performance (i.e., parent-child relationships $\rightarrow$ academic PsyCap $\rightarrow$ academic performance).

\section{Methods}

\section{Participants and Procedure}

The final sample consisted of 402 Chilean high school students -from an original sample size of $414-$ with 3\% missing data. The students came from two different schools (each of them hosted approximately 500 students). They ranged from 12 to 17 years old $(M=13.91, \mathrm{SD}=1.36)$, and $54 \%$ of the sample were female. Of the 402 students, $22 \%$ were 12 years old, $17 \%$ were 13 
years old, $22 \%$ were 14 years old, $26 \%$ were 15 years old, $11 \%$ were 16 years old, and $1 \%$ were 17 years old at the time of data collection. The number of participants in both schools was equal in gender and age, without significant differences between groups.

This study was part of a project designed to examine antecedents and consequences of academic wellbeing, and it received approval from the Research Ethics Committee of the host university. The school principals, students, and students' parents granted their written informed consent. Participants voluntarily completed a questionnaire twice: once at the end of the regular academic semester (Time 1) and once nine weeks later (Time 2). In addition, academic performance was obtained from the teachers' class records at the end of the following academic semester, nine weeks later (Time 3). Participants were encouraged to respond as truthfully as possible, and they were assured that their responses would be anonymous. It took about 20 minutes to fill out the questionnaire using an electronic procedure.

\section{Instruments}

At time 1, parent-child relationships were measured using a Spanish adaptation of the Interpersonal Relationships Scale (Martin et al., 2007). This scale includes four items (e.g., "My parents give me the help and support I need") rated on a scale from 1 (strongly disagree) to 7 (strongly agree). Responses across the four items are averaged to produce a composite score. At time 2, Academic PsyCap was measured using the Academic Psychological Capital Questionnaire (APCQ; Martínez, Meneghel, Carmona-Halty, \& Youssef-Morgan, 2019). This questionnaire is a validated Spanish language adaptation of the Psychological Capital Questionnaire (PCQ; Avey, Avolio, \& Luthans, 2011). The APCQ includes 12 items (e.g. "Right now I see myself as pretty successful in my studies") that evaluate the four PsyCap components (hope-four items; efficacy-three items; resilience-three items; and optimism-two items), rated on a scale ranging from 1 (strongly disagree) to 6 (strongly agree). Responses across the 12 items are averaged to produce a composite score. The validation process for both instruments followed the International Test Commission Guidelines for test translation and adaptation (Muñiz, Elosua, \& Hambleton, 2013). Finally, at time 3, academic performance (AP) was assessed using the GPA provided by the educational institutions at the end of the semester before the data collection for 
three mandatory subjects in the Chilean education curriculum: math, language/communication, and history/geography. According to the Chilean grading system, GPAs range from 1 (poor) to 7 (excellent).

\section{Data Analysis}

All data analyses were conducted using JASP 0.9.01 and SPSS AMOS 23. For preliminary analysis, we examined means, standard deviations, and Pearson's correlation coefficients. For reliability analysis, Cronbach's alpha and McDonald's omega indexes were calculated. For confirmatory factor analysis (CFA) and structural equation modelling (SEM), we used maximum likelihood estimation methods, and the goodness-of-fit of the hypothesized model was evaluated using absolute and relative indexes. That is, chi-square $\left(\chi^{2}\right)$ and normed chi-square $\left(\chi^{2} / d f\right)$, Incremental Fit Index (IFI), Comparative Fit Index (CFI), Root-MeanSquared Error of Approximation (RMSEA) with a confidence interval (90\%), and Standardized Root Mean Residual (SRMR). To determine the fit of the models, we followed the European Journal of Psychological Assessment (Schweizer, 2010) and previous recommendations (Schreiber, Nora, Stage, Barlow \& King, 2006). That is, we consider an acceptable fit model if the normed $\chi^{2}$ is below 3.00; IFI and CFI values are in the range of 0.90-0.95; RMSEA values less than 0.08; and the SRMR value is below 0.10. We examine gender invariance through multigroup CFA and three levels of equivalence (i.e., configural invariance, metric, and scalar invariance) were assessed using changes in CFI as criteria for determining whether measurement invariance was established or not (Cheung \& Rensvold, 2002; Chen, 2007). Finally, to examine direct and indirect effects in our mediation model, we implemented the bootstrapping procedure.

\section{Results}

Table 1 shows means, standard deviations, Cronbach's alpha $(\alpha)$ and McDonald's omega $(\Omega)$ reliability coefficients, and Pearson's PM-correlations among the variables. The internal consistencies obtained for the scales were good (i.e., $\alpha$ and $\Omega \geq .70$ ), and the pattern of correlations revealed significant positive relationships (i.e., $p<.001$ ) for all the measures in our sample, except between parent-child relationships and academic performance. 
Table 1 Means, Standard Deviation (SD), Cronbach's Alpha and McDonald's Omega Indexes, and Pearson correlations

\begin{tabular}{|c|c|c|c|c|c|c|c|c|c|c|c|}
\hline & $\mathrm{M}(\mathrm{SD})$ & $\alpha$ & $\Omega$ & 1 & 2 & 3 & 4 & 5 & 6 & 7 & 8 \\
\hline 1. Age & $13.91(1.36)$ & - & - & - & & & & & & & \\
\hline 2. Parent-Child Relationship & $6.07(1.25)$ & .909 & .909 & $-.145 * * *$ & - & & & & & & \\
\hline 3. Academic PsyCap & $3.93(0.98)$ & .913 & .914 & $-.133 * *$ & $.345^{* *}$ & - & & & & & \\
\hline 4. Hope & $3.87(1.13)$ & .860 & .862 & $-.135 * *$ & $.349 * *$ & $.915^{* *}$ & - & & & & \\
\hline 5. Efficacy & $4.03(1.13)$ & .798 & .798 & $-.076 \mathrm{~ns}$ & $.274 * *$ & $.829 * *$ & $.693 * *$ & - & & & \\
\hline 6. Resilience & $3.82(1.12)$ & .707 & .729 & $-.118 * *$ & $.243 * *$ & $.816^{* *}$ & $.627 * *$ & $.551 * *$ & - & & \\
\hline 7. Optimism & $4.07(1.29)$ & .756 & .756 & $-.118 * *$ & $.292 * *$ & $.815^{* *}$ & $.703 * *$ & $.540 * *$ & $.601 * *$ & - & \\
\hline 3. Academic Performance & $5.55(0.67)$ & .825 & .827 & $.11 * *$ & $.034 \mathrm{~ns}$ & $.266^{* *}$ & $.297 * *$ & $.262 * *$ & $.182 * *$ & $.117 * *$ & - \\
\hline
\end{tabular}

\section{CFA and SEM Analyses}

Table 2 shows the fit indexes for each measurement model and for the hypothesized model. More specifically, parent-child relationships was composed of one factor with four indicators; academic PsyCap was composed of one higher-order factor and four lower-order factors, which, in turn, were formed by 12 indicators; and three indicators made up the latent academic performance factor. Considering the acceptable fit of the measurement models (for details see M1, M2, and M3 in Table 2), a SEM analysis was conducted to test the proposed mediation model after controlling for gender and age. That is, we proposed a direct effect from parent-child relationships to academic PsyCap, from academic PsyCap to academic performance, and from parent-child relationships to academic performance. Results showed that this model exceeded the recommended standards and provided a good representation of the sample relations (M4 in Table 2), explaining 18.2\% of the academic PsyCap variance and 19.1\% of the academic performance variance. In addition, as figure 1 shows, the factor loadings were all moderate to high and statistically significant, and they considerably exceeded the factor-loading criterion of .35 (Byrne, 2010).

Table 2

Results from confirmatory factor analysis, and structural equation modelling

\begin{tabular}{lcccccccc}
\hline & $\chi^{2}$ & $d f$ & $\chi^{2} / d f$ & IFI & CFI & RMSEA & $90 \%$ CI & SRMR \\
\hline M1 Parent-child relationships (PCR) & $7.176^{* *}$ & 2 & 3.588 & .995 & .995 & .080 & {$[.023, .147]$} & .0125 \\
M2 Academic PsyCap & $151.148^{* *}$ & 49 & 3.085 & .959 & .959 & .072 & {$[.059, .085]$} & .0440 \\
M3 Academic Performance & - & - & - & 1.000 & 1.00 & 0 & - & - \\
M4 PCR $\rightarrow$ PsyCap $\rightarrow$ AP & $440.696^{* *}$ & 145 & 3.340 & .910 & .909 & .076 & {$[.064, .079]$} & .0581
\end{tabular}

Note: $* *=p<.001 ; \chi 2=$ Chi-square; $d f=$ degree of freedom; IFI = Incremental Fit Index; CFI = Comparative Fit Index; RMSEA = Root Mean Square Error of approximation; $90 \% \mathrm{CI}=$ Confidence Interval; SRMR = Standardized Root Mean Square Residual; ${ }^{1}=$ saturated model. 


\section{Measurement Invariance Across Gender}

To provide evidence about the applicability of the hypothesized model among boys and girls, we performed a multi-group CFA to examine gender invariance (results in Table 3). The base line model showed an acceptable fit, with support for configural invariance (i.e., same structure across group). In the next step, equality constrains were imposed on all factor loadings to examine metric invariance (i.e., same factor loadings across groups). The resulting model also achieved an acceptable fit. The absolute difference in CFI was less than 0.001. Thus, we concluded that metric invariance across gender is supported. Next, equality constrains were imposed on all intercepts to test scalar invariance (i.e., same intercepts across groups). Following the same reasoning described above, we concluded that scalar invariance across gender is supported. Taken together, we conclude that our proposed mediational model (i.e., parent-child relationship $\rightarrow$ academic PsyCap $\rightarrow$ performance) has the same meaning in our boys' and girls' sample.

\section{Directs and Indirect Effects}

To examine direct and indirect effects in our model, we implemented a bootstrapping procedure, following Hayes (2009), with 5000 new samples taken from our sample. The indirect effect was considered statistically significant if the estimates of the $95 \%$ confidence interval (CI) did not contain zero. The results led us to conclude that: 1) parent-children relationships is significantly related to academic PsyCap $(a=.361, \mathrm{SE}=.052, \mathrm{BCa} 95 \%$ CI $[.262, .467], \mathrm{p}<$ $.001)$; 2) academic PsyCap is significantly related to academic performance after controlling for parent-children relationships $(b=.433, \mathrm{SE}=.061, \mathrm{BCa} 95 \%$ CI $[.311, .549], \mathrm{p}<.001)$; and 3$)$ the indirect effect between parent-children relationships and academic performance -via academic PsyCap- is statistically significant $(a b=.156, \mathrm{SE}=.035, \mathrm{BCa} 95 \%$ CI $[.099, .236], \mathrm{p}$ $<.001)$. In addition, parent-children relationships are not significantly related to academic performance $(c=.079, \mathrm{SE}=.063, \mathrm{BCa} 95 \% \mathrm{CI}[-.200, .049], \mathrm{p}=.213)$. Hence, we can conclude that academic PsyCap fully mediates the relationship between parent-children relationships and academic performance. 


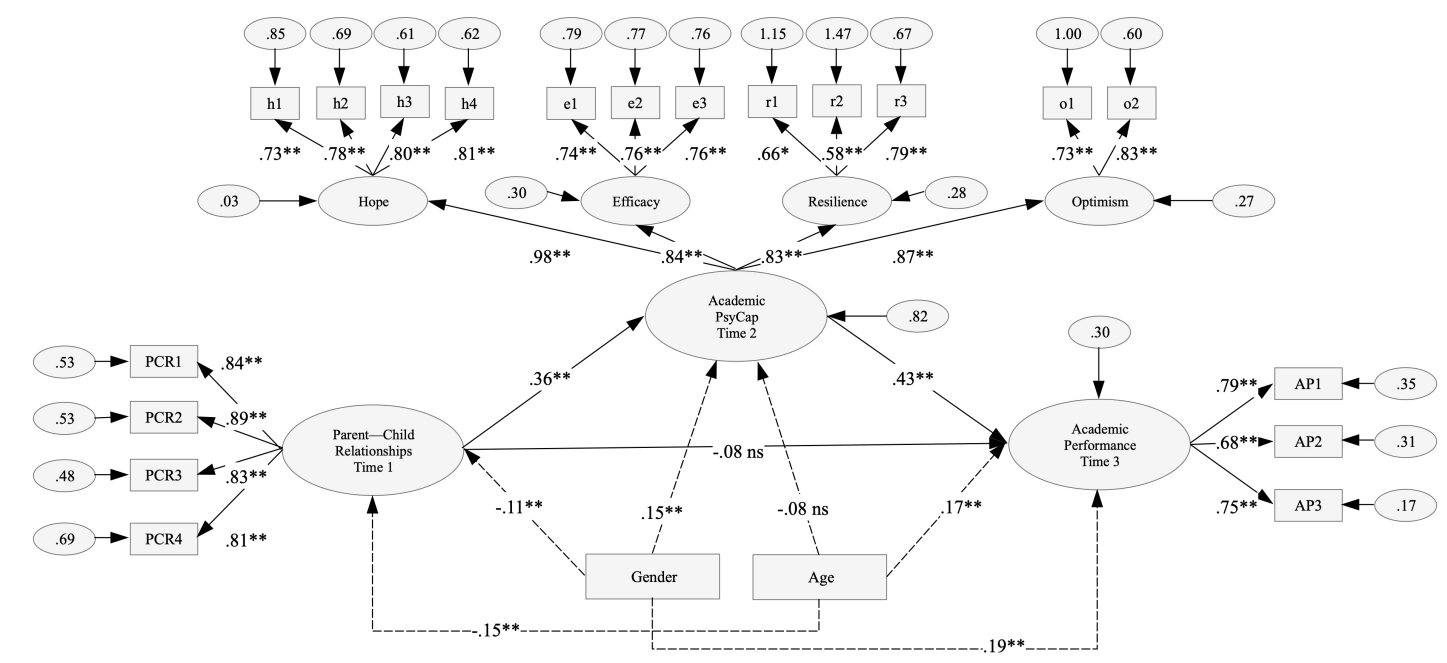

Figure 1

Single mediation model shows the effect of parent-child relationships on academic performance through academic psychological capital. Standardized coefficients are presented. $* *=p<.001 ; \mathrm{ns}=$ non-significant effects.

Table 3

Test of gender Invariance on the Hypothesized Mediation Model

\begin{tabular}{lcccccccccc}
\hline & $\chi^{2}$ & $d f$ & $\chi^{2} / d f$ & IFI & TLI & RMSEA & $90 \%$ CI & SRMR & CFI & $\Delta$ CFI \\
\hline Configural invariance & $619.014^{* *}$ & 290 & 2.135 & .919 & .904 & .053 & {$[.047, .059]$} & .0571 & .918 & - \\
Metric invariance & $633.699 * *$ & 303 & 2.091 & .919 & .907 & .052 & {$[.047, .058]$} & .0591 & .918 & 0.000 \\
Scalar invariance & $687.025^{* *}$ & 320 & 2.140 & .909 & .903 & .054 & {$[.048, .059]$} & .0600 & .909 & 0.009 \\
\hline
\end{tabular}

Note: ${ }^{* *}=\mathrm{p}<.001 ; \chi 2=$ Chi-square; $\mathrm{df}=$ degree of freedom; IFI = Incremental Fit Index; CFI = Comparative Fit Index; RMSEA = Root Mean Square Error of approximation; 90\% CI = Confidence Interval; SRMR $=$ Standardized Root Mean Square Residual; ${ }^{1}=$ boys' sample; ${ }^{2}=$ girls' sample.

\section{Discussion}

The present study contributes to the scarce evidence about the antecedents of academic PsyCap and, more specifically, the role of parents in its prediction. The study's theoretical contribution emphasizes the role of parents in academic PsyCap, whereas its practical contributions focus on possible ways to increase academic PsyCap through evidence-based programs. We describe them below, and we also discuss strengths and weaknesses of the present study and suggestions for future research.

\section{Theoretical Contribution}

First, we found that parent-child relationships is directly associated with academic PsyCap. This result suggests that children who perceive high-quality relationships with their parents are more likely to report high levels of academic PsyCap, which is coherent with previous research that shows the relevance of significant others in children's academic outcomes (Datu, 2017; Furrer \& Skinner, 2002; Guay et al., 2008). That is, we confirm that a high-quality parent- 
child relationships can be considered a relevant antecedent of academic PsyCap. This is an important contribution that expands the future academic PsyCap agenda because it identifies parents as relevant actors in building their children's personal academic resources. In this line, due the family is (one of) the most important and immediate context that influence how vulnerable or resilient are the adolescents, an optimal relationships with parents can promote PsyCap (and other personal resources) because they experience a safety net that leads his grow and develop (Carmona-Halty et al., 2019a; Liu, Wang, \& Tian, 2019; Rey, Pena, \& Neto, 2020).

Second, we found that academic PsyCap is directly associated with academic performance, GPA. This result suggests that children who report high levels of academic PsyCap are more likely to obtain better performance over time. That is, we confirm that academic performance is higher when children simultaneously may draw upon four personal resources that make up the academic PsyCap construct (i.e., hope, efficacy, resilience, and optimism). This is an important contribution because - to date- there is scarce evidence about the applicability of the PsyCap construct in high school settings and its subsequent impact on objective academic performance (e.g., Carmona-Halty et al., 2019b; Datu et al., 2016). In addition, our findings are coherent with previous research that shows the predictive role of academic PsyCap for several academic outcomes, including academic performance (Carmona-Halty et al., 2019b; Datu et al., 2016; Ortega-Maldonado \& Salanova, 2018). In addition, findings are coherent with previous research that shows the predictive role of academic PsyCap for several academic outcomes, including academic performance (Carmona-Halty et al. 2019a; Datu et al. 2016; OrtegaMaldonado \& Salanova, 2018).

Third, we found that parent-child relationships is indirectly associated with academic performance over time through a direct relationship with academic PsyCap what mediates this association. In addition, although boys and girls could differ in the study variables levels, we provide gender invariance evidence that confirmed the mediating role of academic PsyCap in both samples. This result suggests that students who perceive high-quality relationships with their parents are more likely to obtain better performance through the deployment of their academic PsyCap resources, irrespective of their gender. This mediation can be explained by integrating 
both self-determination theory (Ryan \& Deci, 2000) and conservation of resources theory (Hobfoll, 2002). Namely, when children feel that their parents satisfy their need for relatedness (through close relationships with them), they will be able focus on envision goals and challenges and open their mind to productive ways of thinking and problem-solving (i.e., accumulating personal resources), which, in turn, give enable them to effectively deal with their academic environment and obtain an adequate level of academic performance.

\section{Practical Implications}

The first practical implication of our study is related to the relevance of promoting positive relationships between parents and children in family settings. Our findings lead us to conclude that adequate parent-child relationships will -through academic PsyCap-translate into better academic performance. In order to materialize this assumption, the strength-based parenting (SBP) conceptualization -a style of parenting that seeks to deliberately identify and cultivate positive states, positive processes, and positive qualities in one's children- can be used as a reference framework for future interventions (see Waters, 2015a; 2015b). For instance, a recent study illustrates that an SBP intervention increased parents' self-efficacy -greater confidence and perceived ability to successfully raise their children- and fostered positive emotions when thinking about their children (Waters \& Sun, 2017). Thus, the SBP can be useful in providing adequate conditions and timely guidance to parents who do not have or have not yet acquired the necessary skills to foster their children's development.

The second practical implication of our study is related to the relevance of promoting high levels of academic PsyCap. Our findings allow us to conclude that high levels of academic PsyCap are likely to translate into better academic performance. Previous studies demonstrated the possibility of improving each individual PsyCap resource through a structured PsyCap intervention (PCI; see Luthans, Avey, \& Patera, 2008; Luthans, Avey, Avolio, \& Peterson, 2010). However, it is important to note that -to date- the benefits of PCIs have not been examined in high school contexts. Therefore, it would be interesting to adapt and verify their effectiveness in this academic context. This may provide an opportunity to integrate additional aspects, which are not considered in traditional PCI, thereby promoting the PsyCap components and relevant 
antecedents such as experiencing positive study-related emotions (Carmona-Halty et al., 2019c), as well as our results showing the relevance of parent-child relationships.

\section{Strengths, Weakness, and Suggestions for Future Research}

The present study has several strengths. First, we use a longitudinal approach that is not only scarce in previous academic PsyCap research (e.g., Datu et al., 2016), but more generally in testing mediation effects. Second, instead of self-reports, we include an objective measure of academic performance (i.e., GPA). Third, we successfully integrate family factors as an antecedent of academic PsyCap, an aspect not previous studied empirically. However, the study has some weaknesses that must be acknowledged. First, the correlational nature of this study precludes us from drawing causal conclusions. Second, we use self-reports for both psychological measures (i.e., parent-child relationships and academic PsyCap). It would be interesting to include parent's reports about their perceptions of their relationships with their children. Third, only unidirectional effects were examined (i.e., parent-child relationships $\rightarrow$ academic PsyCap $\rightarrow$ academic performance). It would be interesting to use a cross-lagged model to examine (possible) bi-directional effects. Fourth, our proposed model only covers short-term effects instead of capturing long-term effects. Fifth, only a high school sample was used. It would be interesting to include undergraduate university students to examine (possible) differences in the study variables between academic levels.

Finally, some avenues for future research can be mentioned. First, based on the role that significant others play in young people (Furrer \& Skinner, 2003; Martin \& Dowson, 2009), other significant relationships could be included as well in order to establish their unique contribution to academic PsyCap (e.g., with other family members, friends, teachers, and peers). Second, additional aspects of parent-child relationships, such as economic or instrumental support, could be included in a comprehensive model that examines which aspects of family support are more relevant in the prediction of academic PsyCap and academic performance. Third, based on previous research that reports a significant association between SBP and wellbeing in children and adolescents (Jach, Sun, Loton, Chin \& Waters, 207; Waters, 2015a), it could be interesting to examine the relationships between SBP and academic PsyCap and performance. 


\section{References}

Ahmed, W., Minnaert, A., van der Werf, G., \& Kuyper, H. (2010). Perceived social support and early adolescents' achievement: The mediational roles of motivational beliefs and emotions. Journal of Youth and Adolescence, 39, 36-46. https://doi.org/10.1007/s10964-008-9367-7

Alnabhan, M., Al-Zegoul, E., \& Harwell, M. (2001). Factors related to achievement levels of education students at Mu'tah University. Assessment \& Evaluation in Higher Education, 26(6), 593-604. https://doi.org/10.1080/02602930120093913

Anderson, R. E. (2018). And still we rise: parent-child relationships, resilience, and school readiness in low-income urban black families. Journal of Family Psychology, 32, 60-70. https://doi.org/10.1037/fam0000348

Avey, J. B., Avolio, B. J., \& Luthans, F. (2011). Experimentally analysing the impact of leader positivity on follower positivity and performance. The Leader Quarterly. 22, 282-294. https://doi.org/10.1016/j.leaqua.2011.02.004

Bandura, A. (1997). Self-efficacy: The exercise of control. New York: Freeman.

Bergin, C., \& Bergin, D. (2009). Attachment in the classroom. Educational Psychologist, 21, 141-170. https://doi.org/10.1007/s10648-009-9104-0

Bowlby, J. (1969). Attachment and loss: Vol. 1. Attachment. New York, NY: Basic Books.

Byrne, B. (2010). Structural Equation Modelling with AMOS. Basic Concepts, Applications, and Programming. New York, NY: Routledge.

Carmona-Halty, M., Schaufeli, W. B., \& Salanova, M. (2019a). Good relationships, good performance: The mediating role of psychological capital - A three-wave study among students. Frontiers in Psychology, 10, 2113. https://doi.org/10.3389/fpsyh.2019.00306

Carmona-Halty, M., Schaufeli, W. B. Llorens, S., \& Salanova, M. (2019b). Satisfaction of basic psychological needs leads to better academic performance via increased psychological capital: A three-wave longitudinal study among high school students. Frontiers in Psychology, 10, 2113. https://doi.org/10.3389/fpsyg.2019.02113 
Carmona-Halty, M., Salanova, Llorens, S., \& Schaufeli, W. B. (2019c). How psychological capital mediates between study-related positive emotions and academic performance. Journal of Happiness Studies, 20, 605-617. https://doi.org/10.1007/s10902-018-9963-5

Chen, F. F. (2007). Sensitivity of goodness of fit indexes to lack of measurement invariance. Structural Equation Modelling: A Multidisciplinary Journal, 14(3). https://doi.org/10.1080/10705510701301834

Cheng, W., Ickes, W., \& Verhofstadt, L. (2012). How is family support related to students' GPA scores? A longitudinal study. Higher Education, 64, 399-420. https://doi.org/10.1007/s10734-011-9501-4

Chen, Q., Kong, Y., Gao, W., \& Mo, L. (2018). Effects of socioeconomic status, parent-child relationship, and learning motivation on reading ability. Frontiers in Psychology, 9, 1297. https://doi.org/10.3389/fpsyg.2018.01297

Cheung, G. W., \& Rensvold, R. B. (2002). Evaluating goodness-of-fit indexes for testing measurement invariance. Structural Equation Modelling, 9(2), 233-255. https://doi.org/10.1207/s15328007sem0902_5

Cutrona, C. Cole, V., Colangelo, N., Assouline, S., \& Russell, D. (1994). Perceived parental social support and academic achievement: An attachment theory perspective. Journal of Personality and Social Psychology, 66(2), 369-378.

https://doi.org/10.1037/0022-3514.66.2.369

Datu, J. A. D. (2017). Sense of relatedness is linked to higher grit in a collectivist setting. Personality and individual Differences, 105, 135-138. https://doi.org/10.1016/j.paid.2016.09.039

Datu, J. A. D., King, R. B., \& Valdez, J. P. M. (2016). Psychological capital bolsters motivation, engagement, and achievement: Cross-sectional and longitudinal studies. Journal of Positive Psychology, 13, 260-270. https://doi.org/10.1080/17439760.2016.1257056

Datu, J. A. D., \& Valdez, J. P. M. (2019). Psychological capital is associated with higher levels of life satisfaction and school belongingness. School Psychology International, 40, 331346. https://doi.org/10.1177/0143034319838011 
DeBerard, M., Spielman, G., \& Julka, D. (2004). Predictors of academic achievement and retention among college freshmen: A longitudinal study. College Student Journal, 38, 66-80. https://doi.org/10.1007/s10734-011-9501-4

Elmore, G. M., \& Huebner, E. S. (2010). Adolescents' satisfaction with school experiences: relationships with demographics, attachment relationships, and school engagement behaviour. Psychology in the Schools, 47(6), 525-537. https://doi.org/10.1002/pits.20488

Fan, X. (2001). Parental involvement and students' academic achievement: A growth modelling analysis. The Journal of Experimental Education, 70(1), 27-61. https://doi.org/10.1080/00220970109599497

Furrer, C., \& Skinner, E. (2003). Sense of relatedness as a factor in children's academic engagement and performance. Journal of Educational Psychology, 95, 148-162. https://doi.org/10.1037/0022-0663.95.1.148

Guay, F., Marsh, H. W., Senécal, C., \& Dowson, M. (2008). Representations of relatedness with parents and friends and autonomous academic motivation during the late adolescenceearly adulthood period: Reciprocal or unidirectional effects? British Journal of Educational Psychology, 78(4), 621-637. https://doi.org/10.1348/000709908x280971

Hayes, A. F. (2009). Beyond baron and Kenny: Statistical mediation analysis in the new millennium. Communication Monographs, 76(4), 408-420. https://doi.org/10.1080/03637750903310360

Hobfoll, S. E. (2002). Social and psychological resources and adaptation. Review of General Psychology, 6(4), 307-324. https://doi.org/10.1037///1089-2680.6.4.307

Huang, C. Y., Yu, C. Y., \& Wu, I. H. (2018). Relationships between the parent-child interaction, self-concept, and school adjustment of junior high school students with disabilities. Journal of Research in Education Sciences, 63, 103-140. https://doi.org/10.6209/JORIES.2018.63(1).04

Jach, H. K., Sun, J., Loton, D., Chin, T. C., \& Waters, L. E. (2017). Strengths and subjective wellbeing in adolescence: Strength-based parenting and the moderating effect of 
mindset. Journal of Happiness Studies. https://doi.org/10.1007/s10902-016-9841-y

King, R. B. (2015). Sense of relatedness boosts engagement, achievement, and well-being: A latent growth model study. Contemporary Educational Psychology, 42, 26-38. https://doi.org/10.1016/j.cedpsych.2015.04.002

Liao, R., \& Liu, Y. (2016). The impact of structural empowerment and psychological capital on competence among Chinese baccalaureate nursing students: A questionnaire survey. Nurse Education Today, 36, 31-36. https://doi.org/10.1016/.nedt.2015.07.003

Liran B. H., \& Miller, P. (2017). The role of psychological capital in academic adjustment among university students. Journal of Happiness Studies. https://doi.org/10.1007/s10902-017-9933-3

Liu, L., Wang, N., \& Tian, L. (2019). The parent-adolescents relationships and risk-taking behaviours among Chinese adolescents: The moderating role of self-control. Frontiers in Psychology, 10:542. https://doi.org/10.3389/fpsyg.2019.00542

Luthans, F., Avey, J. B., Avolio, B. J., \& Peterson, S. (2010). The development and resulting performance impact on positive psychological capital. Human Resources Development Quarterly, 21, 41-66. https://doi.org/10.1002/hrdq.20034

Luthans, F., Avey, J. B., \& Patera, J. L. (2008). Experimental analysis of a web-based training intervention to develop positive psychological capital. Academy of Management Learning \& Education, 7(2), 209-221. https://doi.org/10.5465/AMLE.2008.32712618

Luthans, F., Avolio, B. J., Avey, J. B., \& Norman, S. M. (2007). Positive psychological capital: Measurement and relationships with performance and satisfaction. Personnel Psychology, 60(3), 541-572. https://doi.org/10.1111/j.1744-6570.2007.00083.x

Luthans, B. C., Luthans, K. W., \& Jensen, S. M. (2012). The impact of business school students' psychological capital on academic performance. Journal of Education for Business, 87, 253-259. https://doi.org/10.1080/08832323.2011.609844

Luthans, F., \& Youssef-Morgan, C. M. (2017). Psychological capital: An evidence-based positive approach. Annual Review of Organizational Psychology and Organizational Behaviour. https://doi.org/10.1146/annurev-orgpsych-032516-113324 
Luthans, F., Youssef-Morgan, C. M., \& Avolio, B. (2015). Psychological Capital and Beyond. New York: Oxford University Press.

Martin, A. J., \& Dowson, M. (2009). Interpersonal relationships, motivation, engagement, and achievement: Yields for theory, current issues, and educational practice. Review of Educational Research, 79, 327-365. https://doi.org/10.3102/0034654308325583

Martin, A. J., Marsh, H. W., McInerney, D. M., Green, J., \& Dowson, M. (2007). Getting along with teachers and parents: The yields of good relationships for students' achievement motivation and self-esteem. Australian Journal of Guidance \& Counselling, 17(2), 109-125. https://doi.org/10.1375/ajgc.17.2.109

Martínez, I. M., Meneghel, I., Carmona-Halty, M., \& Youssef-Morgan, C. M. (2019). Adaptation and validation to Spanish of the Psychological capital Questionnaire 12 (PCQ-12) in academic contexts. Current Psychology. https://doi.org/10.1007/s12144-019-00276-Z

Muñiz, J., Elosua, P., \& Hambleton, R. K. (2013). International Test Commission Guidelines for Test translation and adaptation: Second edition. Psicothema, 25(2), 151-157. https://doi.org/10.7334/psicothema2013.24

Ortega-Maldonado, A., \& Salanova, M. (2018). Psychological capital and performance among undergraduate students: The role of meaning-focused coping and satisfaction. Teaching in Higher Education, 23(3), 390-420. https://doi.org/10.1080/13562517.2017.1391199

Rey, L., Pena, M., \& Neto, F. (2020). Editorial: protective resources for psychological well-being of adolescents. Frontiers in Psychology, 11:720. https://doi.org/10.3389/fpsyg.2020.00720

Richardson, M., Abraham, C., \& Bond, R. (2012). Psychological correlates of university students' academic performance: A systematic review and meta-analysis. Psychological Bulletin, 138(2), 353-387. https://doi.org/10.1037/a0026838

Román, S., Cuestas, P. J., \& Fenollar, P. (2008). An examination of the interrelationships between self-esteem, others' expectations, family support, learning approaches and academic achievement. Studies in Higher Education, 33(2), 127-138. 
https://doi.org/10.1080/03075070801915882

Roorda, D. L., Koomen, H. M. Y., Split, J. L., \& Oort, F. J. (2011). The influence of affective teacher-student relationships on students' school engagement and achievement: A meta-analytic approach. Review of Educational Research, 81(4), 493-529. https://doi.org/10.3102/0034654311431793

Ryan, R. M., \& Deci, E. L. (2000). Self-determination theory and the facilitation of intrinsic motivation, social development, and well-being. American Psychologist, 55, 68-78. https://doi.org/10.1037/0003-066X.55.1.68

Schaufeli, W. B., Martínez, I. M., Marques-Pinto, A., Salanova, M., \& Bakker, A. (2002). Burnout and engagement in university students: A cross-national study. Journal of Cross-Cultural Psychology, 33(5), 464-481. https://doi.org/10.1177/0022022102033005003

Schweizer, K. (2010). Some guidelines concerning the modelling of traits and abilities in test construction. European Journal of Psychological Assessment, 26, 1-2. https://doi.org/10.1027/1015-5759/a000001

Schreiber, J. B., Nora, A., Stage, F. K. Barlow, E., \& King, J. (2006). Reporting structural equation modelling and confirmatory factor analysis results: A review. The Journal of Educational research, 99(6), 323-338. https://doi.org/10.3200/JOER.99.6.323-338

Seligman, M. E. P., Ernst, R. M., Gillham, J., Reivich, K., \& Linkins, M. (2009). Positive education: Positive psychology and classroom interventions. Oxford Review of Education, 35(3), 293-311. https://doi.org/10.1080/03054980902934563

Siu, O. L., Bakker, A. B., \& Jiang, X. (2014). Psychological capital among university students: Relationships with study engagement and intrinsic motivation. Journal of Happiness Studies, 15, 979-994. https://doi.org/10.1007\%s10902-013-9459-2

Sulea, C., van Beek, L., Sarbescu, P., Virga, D., \& Schaufeli, W. B. (2015). Engagement, boredom, and burnout among students: Basic need satisfaction matter more than personality traits. Learning and Individual Differences, 42, 132-138. https://doi.org/10.1016/j.lindif.2015.08.018 
Toor, K. K. (2018). Parent-child relationships and students' academic achievement: A study of secondary school students. Journal of Educational Studies Trends and Practices, 8, 3856.

Vanno, V., Kaemkate, W., \& Wongwanich, S. (2014). Relationships between academic performance, perceived group psychological capital and positive psychological capital on Thai undergraduate students. Social and Behavioural Sciences, 116, 3226-3230. https://doi.org/10.1016/j.sbspro.2014.01.739

Waters, L. (2015a). Strength-based parenting and life satisfaction in teenagers. Advances in Social Science Research Journal, 2(11), 158-173. https://doi.org/10.14738/assrj.211.1651

Waters, L. (2015b). The relationship between strength-based parenting with children's stress levels and strength-based coping approaches. Psychology, 6, 689-699. https://doi.org/10.4236/psych.2015.66067

Waters, L., \& Sun, J. (2017). Can a brief strength-based parenting intervention boost selfefficacy and positive emotions in parents? International Journal of Applied Positive Psychology, 1, 41-56. https://doi.org/10.1007/s41042-017-0007-X

You, J. (2016). The relationship among college student's psychological capital, learning empowerment, and engagement. Learning and Individual Differences, 49, 17-24. https://doi.org/10.1016/j.lindif.2016.05.001 


\title{
Chapter 6
}

\section{Satisfaction of Basic Psychological Needs Leads to Better Academic Performance Via Increased Psychological Capital: A Three-wave Longitudinal Study Among High School Students *}

\begin{abstract}
This brief report proposes a model in which academic psychological capital (PsyCap) mediates between the satisfaction of student's basic psychological needs and their academic performance, as assessed by students' GPA. Participants were 407 adolescents, aged 12-18, recruited from different Chilean schools. Through structural equation modelling, direct and indirect effects were calculated. Results show that academic PsyCap (assessed at time 2) fully mediates the relationship between the satisfaction of basic psychological needs (assessed at time 1) and academic performance (assessed at time 3). This means that students whose basic psychological needs are satisfied at school experience more hope, efficacy, resilience, and optimism (PsyCap), which, in turn, leads to better academic performance. Both theoretical and practical implications of the results are addressed, as well as strengths and weaknesses and directions for future research.
\end{abstract}

Keyword basic psychological needs; academic PsyCap; academic performance

Marcos Carmona-Halty ${ }^{1}$

Wilmar B. Schaufeli ${ }^{2,3}$

Susana Llorens ${ }^{4}$

Marisa Salanova ${ }^{4}$

${ }^{1}$ Escuela de Psicología y Filosofía, Universidad de Tarapacá, Arica, Chile

${ }^{2}$ Research Unit Occupational \& Organizational Psychology and Professional Learning, KU Leuven, Louvain, Belgium

${ }^{3}$ Department of Psychology, Utrecht University, Utrecht, The Netherlands

${ }^{4}$ WANT Research Team, Universitat Jaume I, Castellón de la Plana, Spain

\footnotetext{
* Carmona-Halty, M., Schaufeli, W. B., Llorens, S., \& Salanova, M. (2019). Satisfaction of basic psychological needs leads to better academic performance via increased psychological capital: A three-wave longitudinal study among high school students. Frontiers in Psychology, 10: 2113. https://doi.org/10.3389/fpsyg.2019.02113
} 


\section{Introduction}

The emergence of positive education -focused on both traditional skills and happiness (Seligman, Ernst, Gillham, Reivich, \& Linkins, 2009)- has made it possible to incorporate some recent constructs embraced in positive psychology into the educational research agenda. One of them is academic PsyCap: a psychological state of development that is characterized by hope, efficacy, resilience, and optimism (Luthans, Luthans, \& Jensen, 2012). However, given the relative novelty of the PsyCap construct, little is known about how students' perceptions of their school environment may predict its subsequent appearance (Carmona-Halty, Salanova, Llorens, \& Schaufeli, 2019a). The current study addresses this issue by proposing that the satisfaction of students' basic psychological needs (BPN) - grounded in Self-Determination Theory (SDT; Ryan \& Deci, 2000)- could be a relevant antecedent of academic PsyCap, which, in turn, -according to Conservation of Resources (COR) theory (Hobfoll, 1989)- would predict their academic performance (AP), assessed through their grade point average (GPA). In other words, academic PsyCap is expected to mediate between the satisfaction of BPN at school and AP. Providing empirical evidence about the predictive role of the school environment -described as a context for supporting basic psychological needs (Ryan \& Deci, 2017b)- in academic PsyCap can help to expand our knowledge about possible ways to improve academic PsyCap through evidencebased interventions in the school community.

SDT states that there are specifiable psychological and social nutrients (the so-called BPN), which, when satisfied within the interpersonal and cultural contexts of an individual's development, facilitate growth, integrity, and well-being (Ryan \& Deci, 2017a). In other words, satisfying people's BPN -for autonomy, competence, and relatedness- enhances their development, either in general or in specific domains, such as education (Ryan \& Deci, 2000). In brief, autonomy refers to feeling willingness and volition with regard to one's behaviours; competence refers to feeling effective in one's interactions with the social environment; and relatedness refers to experiencing that others are responsive and sensitive as well as being able to be responsive and sensitive to others. In a school context, SDT suggests -as confirmed by previous research- that when the conditions of nurturance for holistic development are optimized 
(i.e., providing autonomy, competence, and relatedness), learning and educational outcomes are also optimized (Ryan \& Deci, 2017b). More specifically, the satisfaction of BPN at school is associated with student's prosocial behaviour (Tian, Zhang, \& Huebner, 2018), gratitude (Tian, Pi, Huebner, \& Du, 2016), self-control skills (Orkibi \& Ronen, 2017), academic engagement (Jang, Kim, \& Reeve, 2016), and well-being (Tian, Chen, \& Huebner, 2014), among others (Ratelle \& Duchesne, 2014; Wehmeyer \& Shogren, 2017; Yu, Li, Wang, \& Zhang, 2016).

COR theory states that individuals strive to obtain, retain, and protect their material, social, and personal resources (Hobfoll, 1998, 2002). This means that people try to accumulate resources to preserve and foment their health and well-being (Hobfoll, 2011). COR theory also explains -through the caravan notion- that resources do not occur individually, but rather they appear as co-travellers, in contrast to the general tendency in the research to focus on one resource at a time (Hobfoll, Halbesleben, Neveu, \& Westman, 2018). In this regard, the PsyCap construct is an example of a resources caravan because when the four resources it includes (i.e., hope, efficacy, resilience, and optimism) are combined into one core construct -based on their commonalities and in their unique contributions-, they have a joint impact on people's attitudes, behaviours, well-being, and performance (Luthans \& Youssef-Morgan, 2017). Although initial research on PsyCap was conducted in samples of workers, more recently, the notion of academic PsyCap has received attention in both university and high school students. In these samples, direct associations are demonstrated with coping and satisfaction (Ortega-Maldonado \& Salanova, 2017), academic adjustment (Liran \& Miller, 2017), motivation (Siu, Bakker, \& Jiang, 2014), academic engagement (Carmona-Halty, Salanova, Llorens, \& Schaufeli, 2019b), subjective well-being (Datu, King \& Valdez, 2016), and AP (Carmona-Halty, Schaufeli, \& Salanova, 2019), among others (Datu \& Valdez, 2019; Vanno, Kaemkate, \& Wongwanich, 2014; You, 2016).

By integrating SDT and COR theory, the present study proposes a longitudinal model that hypothesizes that academic PsyCap mediates between the satisfaction of BPN at school and AP. More specifically, we assume that when students perceive that their school environment supports their BPN during daily school life -according to SDT-, they will be more likely to have 
the tools they need to accumulate personal resources (in the form of academic PsyCap). In turn, these increased personal resources -according to COR theory- will lead to achieving better AP. In other words, if student's needs for autonomy, relatedness, and competence are met at school, their hope, efficacy, resilience, and optimism about learning activities will increase, and, consequently, they will perform better. This assumption is supported, on the one hand, by research indicating that students tend to show desirable academic outcomes in situations where the social context is more supportive of their autonomy, competence, and relatedness needs (Jang et al, 2016; Orkibi \& Ronen, 2017; Wehmeyer \& Shogren, 2017) and, on the other hand, by research that identifies academic PsyCap as a predictor of AP (Carmona-Halty et al., 2019b; Datu et al., 2016; Ortega-Maldonado \& Salanova, 2018).

\section{Materials and Methods}

\section{Participants}

The sample was composed of 407 high school students from three Chilean educational institutions. Participants were from 12 to 18 years old $(\mathrm{M}=14.55, \mathrm{SD}=1.77)$, and 51.4\% were female. Of the 407 students, $17.2 \%$ were 12 years old, $15.5 \%$ were $13,17.9 \%$ were $14,13.3 \%$ were $15,18.7 \%$ were $16,15.2 \%$ were 17 , and $2.2 \%$ were 18 years old when the data were collected.

\section{Instruments}

All the instruments were administered using a Spanish adaptation carried out following the guidelines of the International Test Commission for adapting tests across cultures (Muñiz, Elosua, \& Hambleton, 2013). At time 1, the satisfaction of BPN at school was measured using a self-constructed scale based on the Work-related Basic Needs Satisfaction Scale (Van den Broeck, Vansteenkiste, De Witte, Soenens, \& Lens, 2010), adapted for use in educational settings. Our scale has 12 items (e.g., "I have the feeling that I can even accomplish the most difficult tasks at school'), grouped into three subscales (i.e., competence, relatedness, and autonomy). All items are scored on a 7-point rating scale from 1 (strongly disagree) to 7 (strongly agree). At time 2, after nine weeks, academic PsyCap was measured using the Academic Psychological Capital 
Questionnaire (Martínez, Meneghel, Carmona-Halty, \& Youssef-Morgan, 2019). This questionnaire has 12 items that measure the four PsyCap components (e.g., "I usually take stressful things in stride with regard to my studies") on a 6-point rating scale from 1 (strongly disagree) to 6 (strongly agree). At time 3, after another nine weeks, AP was assessed using the grade point average (GPA) provided by the educational institutions, using four mandatory subjects in the Chilean education curriculum: maths, language, history, and science. According to the local grading system, GPAs ranged from 1 (poor) to 7 (excellent).

\section{Procedure}

The recommendations of the Comité Ético y Científico (CEC-UTA) of the Chilean university host were followed in carrying out this study, and written informed consent was obtained from all subjects (i.e., the school principals, students, and students' parents) in accordance with the Declaration of Helsinki. Participants voluntarily filled out a questionnaire on two occasions: once when the regular academic semester ended (Time 1 for the satisfaction of BPN at school) and once after a period of nine weeks (Time 2 for academic PsyCap). In addition, AP was extracted from the teachers' class records at the end of the next academic semester, nine weeks later (Time 3). The same verbal and written instructions for completing the measures were provided. Participants were told to respond as truthfully as possible and assured that their responses would be anonymous. The questionnaire took about 20 minutes to complete using an electronic procedure.

\section{Data Analysis}

All data were analysed using JASP 0.9.01 and SPSS AMOS 23. For reliability analysis, Cronbach's alpha and McDonald's omega indexes were calculated. For structural equation modelling, we used maximum likelihood (ML) estimation methods, and goodness-of-fit was evaluated using absolute and relative indexes: Chi-square $\left(\chi^{2}\right)$ and normed Chi-square $\left(\chi^{2} / d f\right)$; Incremental Fit Index (IFI); Tucker Lewis Index (TLI); Comparative Fit Index (CFI); Root Mean Square Error of approximation (RMSEA) with a 90\% Confidence Interval (CI); and Standardized Root Mean Square Residual (SRMR). To determine the fit of the model, we followed the recommendations of the European Journal of Psychological Assessment (Schweizer, 2010). 
Finally, we implemented the bootstrapping procedure -with 5000 new samples taken from our sample (Hayes, 2009)- in order to: 1) correct for any biasing impact that multivariate nonnormality may have had on the computed chi-square value as a function of using ML estimation (Byrne, 2010; Kline, 2011); and 2) examine direct and indirect effect that were considered statistically significant if the $95 \%$ CI estimates did not contain the value of zero.

\section{Results}

Table 1 display descriptive and reliability information about the study variables. It shows that internal consistencies for the scales were good, and the correlations showed significant direct relationships for all the measures used.

Table 1

Means (M), Standard Deviation (SD), Skewness (S), Kurtosis (K), alpha and omega indexes, and correlations for the study variables

\begin{tabular}{lccccccccc}
\hline & $\mathrm{M}$ & $\mathrm{SD}$ & $\mathrm{S}$ & $\mathrm{K}$ & $\alpha$ & $\omega$ & 1 & 2 & 3 \\
\hline 1. BPN & 5.71 & 1.01 & -1.06 & 1.36 & 0.79 & 0.79 & - & & \\
2. Academic PsyCap & 4.47 & 1.09 & -0.59 & 0.18 & 0.91 & 0.91 & $0.61^{* *}$ & - & \\
3. AP & 5.23 & 0.88 & -0.14 & -0.66 & 0.88 & 0.88 & $0.29^{* *}$ & $0.34^{* *}$ & - \\
& & & & & & & & & \\
\hline
\end{tabular}

$* *=p<.001$

The proposed model contained seven latent factors and 19 indicators (see Figure 1). In other words, one factor that reflects satisfaction of BPN at school using three indicators; one higher-order factor with four lower-order factors, which, in turn, are composed of 12 indicators that make up the academic PsyCap factor; and four indicators that make up the AP factor. Results showed that this model exceeded the recommended standards and was a good representation of the data, explaining $52.0 \%$ of the academic PsyCap variance and $14.3 \%$ of the AP variance: $\chi^{2}=$ $381.965 ; d f=145 ; \chi^{2} / d f=2.634 ; \mathrm{IFI}=.954 ; \mathrm{TLI}=.946 ; \mathrm{CFI}=.954 ; \mathrm{RMSEA}=.063,90 \% \mathrm{CI}$ $[.056, .071] ;$ SRMR $=.047$.

Considering the good fit of the hypothesized model, direct and indirect effects were calculated and are described below. First, the satisfaction of BPN at school is significantly related to academic PsyCap $(a=.721, \mathrm{SE}=.042, \mathrm{BCa} 95 \%$ CI $[.629, .797], \mathrm{p}=.001)$. Second, academic PsyCap is significantly related to AP, after controlling for the satisfaction of BPN at school $(b=$ $.241, \mathrm{SE}=.087, \mathrm{BCa} 95 \% \mathrm{CI}[.071, .405], \mathrm{p}=.010)$. Third, the satisfaction of BPN at school is significantly and indirectly associated with AP through academic PsyCap $(a b=.174, \mathrm{SE}=.063$, 
BCa $95 \%$ CI $[.056, .300], p=.008)$. In addition, because the satisfaction of BPN at school is not significantly related to AP $(c=.165, \mathrm{SE}=.098, \mathrm{BCa} 95 \% \mathrm{CI}[-.028, .356], \mathrm{p}=.088)$, we can conclude that academic PsyCap fully mediates the relationship between the satisfaction of BPN at school and AP.

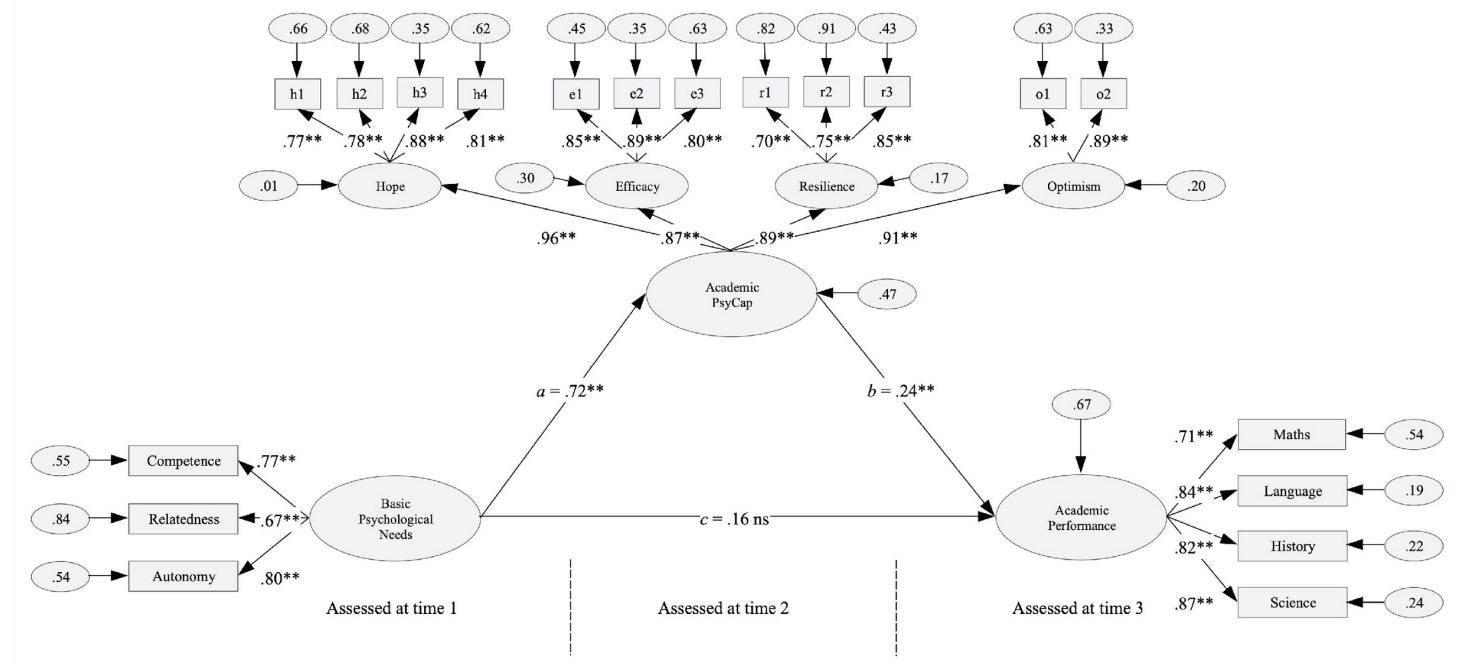

Figure 1

Single mediation model shows the effect of basic psychological needs at school on academic performance through academic PsyCap. Standardized coefficients are presented. $* *=p<.001 ; \mathrm{ns}=$ non-significant effect.

\section{Discussion}

The current paper makes several theoretical contributions. First, we found that the satisfaction of students' BPN is related to their academic PsyCap. Second, we found that the accumulation of personal resources in the form of academic PsyCap is directly related to students' AP. Third, we found that students whose BPN are satisfied at school (i.e., competence, relatedness, and autonomy) are more likely to achieve better academic results (i.e., GPA score) through academic PsyCap (i.e., a resource caravan formed by hope, efficacy, resilience, and optimism). Taken together, these results are in line with previous research on SDT and COR theory, and they make an innovative contribution to the scarce empirical research on school environment variables as antecedents of academic PsyCap (e.g., Carmona-Halty et al., 2019a; Datu \& Valdez, 2019; Orkibi \& Ronen, 2017; Wehmeyer \& Shogren, 2017).

As a main practical implication, we want to emphasize the key role that educational institutions (can) play in increasing students`academic PsyCap. That is, instead of focusing on a 
curriculum based on control and achievement -which thwarts students' BPN fulfilment- the school community should concentrate on creating an environment that sets clear rules and gives students positive feedback (i.e., supporting the need for competence), expresses interest and care for them (i.e., supporting the need for relatedness), and provides them with the freedom to make their own choices (i.e., supporting the need for autonomy). This proposal is coherent with the resource caravan passageways notion, which points out that people's resources exist in an environment that either fosters/nurtures or limits/blocks resource creation or nourishment (see Hobfoll, 2011; Hobfoll et al., 2018). Therefore, the PsyCap components should be enhanced not only through individual-level interventions -using the Psychological Capital Intervention method (Luthans, Avey, \& Patera, 2008; Luthans, Avey, Avolio, \& Peterson, 2010)-, but also through school-level promotion, including a supportive educational curriculum as a strategy to obtain based on our results- better academic performance.

This study has several strengths. First, we used a longitudinal three-wave design, which agrees with the temporal sequence that we assumed in the proposed mediational model. Second, we included the GPA as an objective AP indicator. Third, we empirically demonstrated the integration of both SDT and COR theory in an academic setting. However, this study has also some weaknesses. First, we used a convenience sample instead of a representative Chilean student sample. Second, we used self-report for both psychological measures instead of using, for instance, peer or teachers' ratings. Third, we focused on unidirectional effects instead of examining bi-directional effects. Fourth, our three assessment points (i.e., BPN, academic PsyCap, and AP) only cover short-term effects (approximately five months), instead of capturing long-term effects (e.g., using a two-year longitudinal design). Finally, for future research, we would suggest the following. First, it would be interesting to examine an alternative model proposing that students with high satisfaction of BPN and high PsyCap would have higher AP, whereas students with low satisfaction of needs and low PsyCap would have lower AP. Second, based on the recent team-level PsyCap approach, the applicability of class-level PsyCap should be explored, in order to examine its role in students' individual and/or class-level outcomes such as academic engagement, academic burnout, and AP. Third, the inclusion of other school 
environment variables - such as a sense of community- in a more comprehensive model would be a fruitful future research agenda to expand our knowledge about academic PsyCap antecedents. 


\section{References}

Byrne, B. M. (2010). Structural equation modelling with AMOS: Basic concepts, applications, and programming ( $2^{\text {nd }}$ ed.). New York: Taylor \& Francis.

Carmona-Halty, M., Salanova, M., Llorens, S., \& Schaufeli, W. B. (2019a). How psychological capital mediates between study-related positive emotions and academic performance. Journal of Happiness Studies. https://doi.org/10.1007/s10902-018-9963-5

Carmona-Halty, M., Salanova, M., Llorens, S., \& Schaufeli, W. B. (2019b). Linking positive emotions and academic performance: The mediated role of academic psychological capital and academic engagement. Current Psychology. https://doi.org/10.1007/s12144-019-00227-8

Carmona-Halty, M., Schaufeli, W. B., \& Salanova, M. (2019). Good relationships, good performance: The mediating role of psychological capital - A three-wave study among students. Frontiers in Psychology, 10: 306. https://doi.org/10.3389/fpsyg.2019.00306

Datu, J. A. D., King, R. B., \& Valdez, J. P. M. (2016). Psychological capital bolsters motivation, engagement, and achievement: Cross-sectional and longitudinal studies. Journal of Positive Psychology. https://doi.org/10.1080/17439760.2016.1257056

Datu, J. A. D., \& Valdez, J. P. M. (2019). Psychological capital is associated with higher levels of life satisfaction and school belongingness. School Psychology International, 1-16. https://doi.org/10.1177/0143034319838011

Deci, E. L., \& Ryan, R. M. (2000). The "what" and "why" of goal pursuits: Human needs and the self-determination of behaviour. Psychological Inquiry, 11(4), 227-268. https://doi.org/10.1207/S15327965PLI1104_01

Hayes, A. F. (2009). Beyond baron and Kenny: Statistical mediation analysis in the new millennium. Communication Monographs, 76(4), 408-420. https://doi.org/10.1080/03637750903310360

Hobfoll, S. E. (1989). Conservation of resources: A new attempt at conceptualizing stress. American Psychologist, 44, 513-524. https://doi.org/10.1037/0003-066X.44.3.513

Hobfoll, S. E. (2011). Conservation of resource caravans and engaged settings. Journal of 
Occupational and Organizational Psychology, 84, 116-122.

https://doi.org/10.1111/j.2044-8325.2010.02016.x

Hobfoll, S. E., Halbesleben, J., Neveu, J., \& Westman, M. (2018). Conservation of resources in the organizational context: The reality of resources and their consequences. The Annual Review of Organizational Psychology and Organizational Behaviour, 5, 10.1-10.26. https://doi.org/10.1146/annurev-orgpsych-032117-104640

Jang, H., Kim, E., \& Reeve, J. (2016). Why students become more engaged or more disengaged during the semester: A self-determination theory dual-process model. Learning and Instruction, 43, 27-38. https://doi.org/10.1016/j.learninstruc.2016.01.002

Kline, R. B. (2011). Principles and practice of structural equation modelling ( $3^{\text {rd }}$ ed.). New York: The Guilford Press.

Liran, B. H., \& Miller, P. (2017). The role of psychological capital in academic adjustment among university students. Journal of Happiness Studies.

https://doi.org/10.1007/s10902-017-9933-3

Luthans, F., Avey, J. B., Avolio, B. J., \& Peterson, S. (2010). The development and resulting performance impact on positive psychological capital. Human resources Development Quarterly. 21, 41-66. https://doi.org/10.1002/hrdq.20034

Luthans, F., Avey, J. B., \& Patera, J. L. (2008). Experimental analysis of a web-based training intervention to develop positive psychological capital. Academy of Management Learning \& Education, 7(2), 209-221. https://doi.org/10.5465/AMLE.2008.32712618

Luthans, B. C., Luthans, K. W., \& Jensen, S. M. (2012). The impact of business school students' psychological capital on academic performance. Journal of Education for Business, 87, 253-259. https://doi.org/10.1080/08832323.2011.609844

Luthans, F., \& Youssef-Morgan, C. M. (2017). Psychological capital: An evidence-based positive approach. Annual Review of Organizational Psychology and Organizational Behaviour. https://doi.org/10.1146/annurev-orgpsych-032516-113324

Martínez, I., Meneghel. I., Carmona-Halty, M., \& Youssef-Morgan, C. M. (2019). Adaptation and validation to Spanish of the Psychological Capital Questionnaire 12 (PCQ-12) in 
academic contexts. Current Psychology. https://doi.org/10.1007/s12144-019-00276-Z

Muñiz, J., Elosua, P., \& Hambleton, R. K. (2013). International Test Commission Guidelines for test translation and adaption: Second edition. Psicothema, 25(2), 151-157. https://doi.org/10.7334/psicothema2013.24

Orkibi, H., \& Ronen, T. (2017). Basic psychological needs satisfaction mediates the association between self-control skills and subjective well-being. Frontiers in Psychology, 8: 936. https://doi.org/10.3389/fpsyg.2017.00936

Ortega-Maldonado, A., \& Salanova, M. (2018). Psychological capital and performance among undergraduate students: The role of meaning-focused coping and satisfaction. Teaching in Higher Education, 23(3), 390-420. https://doi.org/10.1080/13562517.2017.1391199

Ratelle, C. F., \& Duchesne, S. (2014). Trajectories of psychological need satisfaction from early to late adolescence as a predictor of adjustment in school. Contemporary Educational Psychology, 39, 388-400. https://doi.org/10.1016/j.cedpsych.2014.09.003

Ryan, R. M., \& Deci, E. L. (2000). Self-determination theory and the facilitation of intrinsic motivation, social development, and well-being. American Psychologist, 55, 68-78. https://doi.org/10.1037/0003-066X.55.1.68

Ryan, R. M., \& Deci, E. L. (2017a). Psychological Needs: Varied concepts and a preliminary description of SDT's Approach. In R. M. Ryan, \& E. L. Deci, Self-Determination Theory: Basic Psychological Needs in Motivation, development, and Wellness (pp. 80101). London: The Guilford Press.

Ryan, R. M., \& Deci, E. L. (2017b). School as contexts for learning and social development. In R. M. Ryan, \& E. L. Deci, Self-Determination Theory: Basic Psychological Needs in Motivation, development, and Wellness (pp. 351-381). London: The Guilford Press.

Schweizer, K. (2010). Some guidelines concerning the modelling of traits and abilities in test construction. European Journal of Psychological Assessment, 26, 1-2. https://doi.org/10.1027/1015-5759/a000001

Seligman, M. E. P., Ernst, R. M., Gillham, J., Reivich, K., \& Linkins, M. (2009). Positive education: Positive psychology and classroom interventions. Oxford Review of 
Education, 35(3), 293-311. https://doi.org/10.1080/03054980902934563

Siu, O. L., Bakker, A. B., \& Jiang, X. (2014). Psychological capital among university students: Relationships with study engagement and intrinsic motivation. Journal of Happiness Studies, 15, 979-994. https://doi.org/10.1007\%s10902-013-9459-2

Tian, L., Chen, H., \& Huebner, E. S. (2014). The longitudinal relationships between basic psychological needs satisfaction at school and school-related subjective well-being in adolescents. Social Indicators Research, 199, 353-372. https://doi.org/10.1007/s11205-013-0495-4

Tian, L., Pi, L., Huebner, E. S., \& Du, M. (2016). Gratitude and adolescents' subjective wellbeing in school: The multiple mediating roles of basic psychological needs satisfaction at school. Frontiers in Psychology, 7:1409. https://doi.org/10.3389/fpsyg.2016.01409

Tian, L., Zhang, X., \& Huebner, E. S. (2018). The effects of satisfaction of basic psychological needs at school on children's prosocial behaviour and antisocial behaviour: The mediating role of school satisfaction. Frontiers in Psychology, 9:548. https://doi.org/10.3389/fpsyg.2018.00548

Van den Broeck, A., Vansteenkiste, M., De Witte, H., Soenens, B., \& Lens, W. (2010). Capturing autonomy, competence, and relatedness at work: Construction and initial validation of the Work-related Basic Need Satisfaction Scale. Journal of Occupational and Organizational Psychology, 83, 981-1002. https://doi.org/10.1348/096317909X481382

Vanno, V., Kaemkate, W., \& Wongwanich, S. (2014). Relationships between academic performance, perceived group psychological capital and positive psychological capital on Thai undergraduate students. Social and Behavioural Sciences, 116, 3226-3230. https://doi.org/10.1016/j.sbspro.2014.01.739

Wehmeyer, M. L., \& Shogren, K. A. (2017). The development of self-determination during adolescence. In M. L. Wehmeyer, K. A., Shogren, T. D. Little, \& S. J. Lopez (Eds), Development of Self-Determination Through the Life-Course (pp. 89-98). Dordrecht: Springer. 
You, J. (2016). The relationship among college student's psychological capital, learning empowerment, and engagement. Learning and Individual Differences, 49, 17-24. https://doi.org/10.1016/j.lindif.2016.05.001

Yu, C., Li, X., Wang, S., \& Zhang, W. (2016). Teacher autonomy support reduces adolescent anxiety and depression: An 18-month longitudinal study. Journal of Adolescence, 49, 115-123. https://doi.org/10.1016/j.adolescence.2016.03.001 


\section{Chapter 7}

\section{Conclusión General}

El objetivo de la presente tesis fue examinar la aplicabilidad del CP académico en un contexto escolar y aportar evidencia empírica sobre sus antecedentes y resultados académicos. A continuación, se comentan -a la luz de las preguntas de investigación identificadas en la revisión de la literatura reciente en torno al CP académico- los resultados de los estudios realizados, las implicaciones teóricas y prácticas del proyecto, y finalmente sus limitaciones y direcciones futuras de estudio en el ámbito del CP académico.

Pregunta de Investigación $\mathbf{N}^{\circ} \mathbf{1}$ ¿Cómo influyen las características individuales positivas en la predicción del CP académico? En los estudios 1 y 2 se hipotetiza que aquellos estudiantes que frecuentemente experimentan emociones/experiencias académicas positivas obtendrán un buen desempeño académico a través de la acumulación de los recursos personales que conforman el CP académico. Los resultados de ambos estudios permitieron confirmar que la categoría individual experimentación de emociones/experiencias positivas influye significativamente en el CP académico (pregunta $\mathrm{N}^{\circ}$ ), el que, a su vez, se relaciona directamente con el bienestar y desempeño académico de los estudiantes (pregunta $\mathrm{N}^{\circ} 4$ ). Además, se encontró que las emociones académicas positivas y el desempeño académico están indirectamente relacionados a través del CP académico.

Pregunta de Investigación $\mathbf{N}^{\circ} 2$ ¿Cómo influyen las relaciones interpersonales positivas en la predicción del CP académico? En los estudios 3 y 4 se hipotetiza que aquellos estudiantes que perciben una relación cálida ya sea con sus profesores como con sus padres obtendrán un buen desempeño a través del CP académico. Los resultados de estos estudios permitieron confirmar que la categoría interpersonal relación positiva profesor-estudiante y padres-estudiante influye significativamente en el CP académico (pregunta $\mathrm{N}^{\circ}$ ), el que, a su vez, se relaciona directamente con el desempeño académico de los estudiantes (pregunta $\mathrm{N}^{\circ} 4$ ). Además, se encontró que la percepción de buena relación y el buen desempeño están indirectamente relacionados a través del CP académico. 
Pregunta de Investigación $\mathbf{N}^{\circ} \mathbf{3}$ ¿Pueden las instituciones educativas favorecer la aparición del CP académico de sus estudiantes? En el estudio 5 se hipotetiza que aquellas instituciones educativas que satisfacen las necesidades psicológicas básicas de sus estudiantes contribuyen a que estos obtengan un buen desempeño a través del incremento de CP académico. Los resultados de este estudio permitieron confirmar que la categoría institución educativa -a través de la creación de un contexto que satisface las necesidades psicológicas básicas de sus estudiantes- influye significativamente en el $\mathrm{CP}$ académico (pregunta $\mathrm{N}^{\circ} 3$ ), el que, a su vez, se relaciona directamente con el desempeño académico de los estudiantes (pregunta $\mathrm{N}^{\circ} 4$ ). Además, se encontró que la satisfacción de necesidades psicológicas básicas y el desempeño académico están indirectamente relacionados a través del CP académico.

Pregunta de Investigación $\mathbf{N}^{\circ} 4$ ¿Cómo influye la presencia del CP académico en el desarrollo de destrezas académicas y en el bienestar de los adolescentes? En la totalidad de estudios se hipotetiza que aquellos estudiantes que poseen el conjunto de recursos personales denominado $\mathrm{CP}$, con mayor probabilidad experimentarán altos niveles de bienestar y desempeño académico. Los resultados de los estudios realizados han permitido confirmar que tanto la adquisición de destrezas académicas - evaluada a partir del desempeño académico obtenido (i.e. GPA)- como los niveles de bienestar académico -evaluado a partir de la noción academic engagement (Schaufeli et al., 2002; Upadyaya y Salmela-Aro, 2013)- son influidos significativamente por la presencia del CP académico (pregunta $\mathrm{N}^{\circ} 4$ ).

\section{Implicaciones Teóricas}

En primer lugar, el conjunto de estudios realizados permite concluir que el $\mathrm{CP}$ es un constructo aplicable al contexto escolar y a los objetivos de la EP. Es decir, el CP resulta de utilidad para comprender los procesos que subyacen al funcionamiento óptimo de los adolescentes en contextos escolares. Adicionalmente, los resultados aquí reportados son coherentes con la literatura previa -tanto en contextos profesionales (p.e., Bockorny y Youssef-Morgan, 2019; Bogler y Somech, 2019; Ozturk y Karatepe, 2019) como pre-profesionales (p.e., Martínez et al., 2019; Ortega-Maldonado y Salanova, 2018; Selvaraj y Bath, 2018)- y permiten ampliar la utilidad del CP hacia dominios escasamente explorados hasta la fecha. En esta dirección, tal y 
cómo mencionamos en el capítulo de introducción, las características que influyen en el éxito académico de los estudiantes no difieren significativamente de las características que influyen en el éxito laboral de los trabajadores; y, por tanto, es probable que el fenómeno abordado en este trabajo obedezca a un principio psicológico general independiente del contexto específico (p.e., profesional, pre-profesional, escolar).

En segundo lugar, se ha propuesto un modelo general de CP académico que incorpora, por un lado, los tres pilares de estudio de la PP, y por otro, el objetivo declarado por la EP (Seligman y Csikszentmihalyi, 2000; Seligman et al., 2009). Esto es, el modelo ha incorporado como antecedentes del $\mathrm{CP}$ académico características individuales, relaciones interpersonales, e instituciones que contribuyen al incremento de los recursos personales que constituyen el CP (i.e., eficacia, optimismo, esperanza, y resiliencia), y cómo este influye en el desarrollo de habilidades académicas (evaluadas a través del desempeño) y el bienestar de los estudiantes. En esta dirección, los estudios realizados -en conjunto- han permitido validar el modelo propuesto, ofreciendo una aportación heurística y flexible, que posibilita la incorporación de constructos no incluidos en la presente propuesta -ya sea dentro de las categorías individual, interpersonal, e institucional, como en los indicadores de bienestar y desempeño académico- que permitan avanzar en la comprensión y predicción del funcionamiento óptimo de los adolescentes en contextos escolares.

\section{Implicaciones Prácticas}

En primer lugar, el conjunto de estudios realizados ofrece algunas directrices interesantes respecto de la posibilidad de implementar intervenciones -basadas en la evidencia- dirigidas a incrementar los niveles de bienestar y desempeño académico en línea con la EP. En esta dirección, adaptar y examinar la eficacia de la Psychological Capital Intervention (Luthans, Avey, Avolio, \& Peterson, 2010; Luthans, Avey, \& Patera, 2008; Luthans y Youssef-Morgan, 2004) en contextos escolares, puede ser considerado un desafío futuro de investigación, y a la vez, una herramienta de intervención relevante para profesores y profesionales de la educación. Adicionalmente, en base al demands-resources model (Bakker y Demerouti, 2007) es posible, por un lado, incrementar los niveles de bienestar académico -en forma de vigor y dedicación- y 
por otro, disminuir los niveles de malestar académico - en forma de agotamiento y cinismo- a través de acciones dirigidas al equilibrio entre demandas (p.e., exceso de actividades académicas) y recursos académicos (p.e., apoyo social percibido) (ver Hodge, Wright, y Bennett, 2017; Salmela-Aro y Upadyaya, 2014).

En segundo lugar, los resultados obtenidos nos permiten visualizar algunas vías alternativas para incrementar los niveles de CP que superan la tradicional visión de la PCI, centrada en el desarrollo de cada uno de los recursos personales que constituyen el constructo (ver Lupsa, Virga, Maricotoiu, \& Rusu, 2019; Luthans, Avey, Avolio, \& Peterson, 2010; Luthans, Avey, \& Patera, 2008). En esta dirección, en base a los antecedentes incluidas en el modelo general de CP, es razonable afirmar que promoviendo dichos antecedentes -es decir, fomentando la frecuencia con que los estudiantes experimentan emociones académicas positivas; incrementando los vínculos interpersonales con otros significativos; y generando un contexto escolar que permita el desarrollo de los estudiantes en términos de satisfacción de necesidades psicológicas básicas- se estará contribuyendo a la acumulación de recursos personales en forma de CP académico.

En ambos puntos resulta relevante remarcar a las escuelas como lugares propicios para el desarrollo y promoción de la salud y bienestar de niños y adolescentes, lo cual reviste de viabilidad las propuestas mencionadas.

\section{Limitaciones}

En primer lugar, la muestra utilizada en el conjunto de estudios $(n=2716)$ no es representativa del contexto escolar chileno, por lo cual, los resultados descritos deben ser generalizados con la debida precaución. Estudios posteriores podrían considerar muestras representativas y diversificadas que incluyan ámbitos académicos adicionales tales como el universitario. Lo anterior permitiría avanzar -por ejemplo- en establecer puntos de corte (p.e., bajo, medio, alto) para los niveles de CP, lo cual -en conjunto a una entrevista- facilitaría posteriores intervenciones relativas a incrementar el CP, bienestar y desempeño académico.

En segundo lugar, los instrumentos utilizados para evaluar las variables contenidas en el modelo propuesto corresponden a autoinformes (excepto la medida de desempeño). Sin embargo, 
el autoinforme suele ser el mejor recurso para aproximarse a la evaluación de un constructo individual (p.e., emociones académicas o recursos personales). Estudios posteriores podrían incorporar reportes externos - de padres y/o profesores- o medidas implícitas con la finalidad de corroborar los resultados aquí obtenidos. En esta dirección, resultaría interesante adaptar y validar el Implicit Psychological Capital Questionnaire (Harms y Luthans, 2012) -una medida implícita de CP que intenta superar los problemas de deseabilidad social presentes tradicionalmente en las medidas de autoinforme- en contextos académicos.

En tercer lugar, los estudios longitudinales realizados abarcan periodos temporales breves de aproximadamente seis meses. Estudios posteriores podrían abarcar periodos temporales de mayor extensión con la finalidad de examinar en qué medida los efectos directos e indirectos reportados en el presente trabajo se extinguen con el paso del tiempo. En esta dirección, resulta necesario indagar en eventuales efectos bidireccionales, en línea con la noción upward spiral process contenida en la teoría B\&B (Fredrikson, 2013; Fredrikson \& Joiner, 2002), y que no han sido considerados en el conjunto de estudios realizados.

\section{Direcciones Futuras en el Estudio del CP Académico}

En primer lugar, resultaría interesante indagar en niveles de análisis alternativos de $\mathrm{CP}$ académico. Por ejemplo, recientemente se ha propuesto -en el ámbito laboral- que el CP puede ser considerado un constructo colectivo (ver Dawkins, Martin, Scott, \& Sanderson, 2015; Heled, Somech, \& Waters, 2016). En esta dirección, se podría explorar la relevancia del CP académico al nivel colectivo y examinar su impacto en diversos resultados académicos individuales y/o grupales. Por otra parte, atendiendo a la diversidad de habilidades que deben desarrollar los estudiantes, es probable que sus niveles de CP difieran entre áreas de conocimiento diferentes (p.e., letras, ciencias, artes). De esta manera, parece relevante atender también a un nivel de CP que considere dominios específicos de desempeño, los cuales no necesariamente pueden ser generalizables a otras actividades académicas. En conjunto, complementar la tradicional visión del CP como un constructo individual y global, con una visión colectiva y específica puede permitir diseños de intervención ad hoc a las necesidades educativas de cada institución escolar. 
En segundo lugar, considerando que el $\mathrm{CP}$ está compuesto por diferentes recursos psicológicos (i.e., eficacia, optimismo, esperanza, y resiliencia), resultaría interesante explorar la existencia de perfiles de $\mathrm{CP}$ académico -es decir, configuraciones basadas en los niveles diferenciados de cada uno de los elementos que lo forman- siguiendo la propuesta de algunos trabajos recientes en el ámbito laboral (p.e., Bouckenooghe, De Clercq, \& Raja, 2018; Djourova, Rodríguez, \& Lorente-Prieto, 2019; Ferradás, Freire, García-Bértoa, Núñez, \& Rodríguez, 2019). De esta manera, acceder a información específica respecto de los niveles de cada uno de los componentes del CP puede facilitar-previo a una intervención- la posibilidad de focalización en el desarrollo de aquellos recursos que se encuentran en niveles deficitarios y en el mantenimiento de aquellos recursos que se encuentran en niveles óptimos, o propuestas de intervención específicas según el perfil de los estudiantes.

En tercer lugar, a pesar de que hemos establecido que mantener una relación cálida con otros significativos puede ser considerado un antecedente relevante del $\mathrm{CP}$ académico, es posible ir un paso más allá -basándonos en el crossover model (ver Westman, 2001; Westman et al., 2009; 2013) y la noción resources caravan passageways (ver Hobfoll, 2011; Hobfoll et al., 2018)- examinando si existe algún tipo de transferencia entre los recursos psicológicos de padres y profesores, hacia los estudiantes. Es decir, resultaría interesante conocer en qué medida rodearse de personas con altos niveles de eficacia, optimismo, esperanza, y resiliencia, se asocia con la acumulación de dichos recursos por parte de quienes los poseen en menor medida y la obtención de resultados académicos similares a los descritos en este trabajo (bienestar y desempeño).

Finalmente, si bien el modelo propuesto examina el rol mediador del CP entre diferentes categorías de antecedentes (i.e., individual, interpersonal, e institucional) y el bienestar y desempeño académico, futuras investigaciones podrían examinar si estos antecedentes, pueden actuar también como un moderador de la relación entre CP y bienestar y desempeño académico. Es decir, aquellos estudiantes - por ejemplo- con una alta satisfacción de sus necesidades psicológicas básicas y un alto CP serían los de mayor rendimiento académico, mientras que los estudiantes con necesidades de baja satisfacción y CP serían los de menor rendimiento académico. En la misma dirección, variables tales como el clima de aprendizaje, número de horas de estudio, 
y apoyo social podrían incorporarse al análisis de los efectos moderadores dentro del modelo de CP propuesto.

\section{Referencias}

Bakker, A. B., \& Demerouti, E. (2007). The job demands-resources model: State of the art. Journal of Managerial Psychology, 22(3), 309-328. https://doi.org/10.1108/02683940710733115

Bockorny, K., \& Youssef-Morgan, C. M. (2019). Entrepreneurs' courage, psychological capital, and life satisfaction. Frontiers in Psychology, 10:789, 1-6. https://doi.org/10.3389/fpsyg.2019.00789

Bogler, R., \& Somech, A. (2019). Psychological capital, team resources and organizational citizenship behaviour. The Journal of Psychology, 153(8), 784-802. https://doi.org/10.1080/00223980.2019.1614515

Bouckenooghe, D., De Clercq, D., \& Raja, U. (2018). A person-centered, latent profile analysis of psychological capital. Australian Journal of Management, 44, 91-108. https://doi.org/10.1177/0312896218775153

Dawkins, S., martin, A., Scott, J., \& Sanderson, K. (2015). Advancing conceptualization and measurement of psychological capital as a collective construct. Human Relations, 68(6), 925-949. https://doi.org/10.1177/0018726714549645

Diener, E., Wirtz, D., Kim-Prieto, C., Choi, D., Oishi, S., \& Biswas-Diener, R. (2010). New wellbeing measures: Short scales to assess flourishing and positive and negative feelings. Social Indicators Research, 97(2), 143-156. https://doi.org/10.1007/s11205-009-9493-y

Djourova, N. P., Rodríguez, I., \& Lorente-Prieto, L. (2019). Individual profiles of psychological capital in a Spanish sample. Journal of Social Science Research, 14, 3029-3047. https://doi.org/10.24297/jssr.v14i0.8042

Ferradás, M., Freire, C., García-Bértoa, A., Núñez, J. C., \& Rodríguez, S. (2019). Teacher profiles of psychological capital and their relationship with burnout. Sustainability, 11, 5096. https://doi.org/10.1177/0018726714549645

Fredrikson, B. L. (2013). Positive emotions broaden and build. Advances in Experimental 
Social Psychology, 47, 1-53. https://doi.org/10.1016/B978-0-12-407236-7.00001-2

Fredrikson, B. L., \& Joiner, T. (2002). Positive emotions trigger upward spirals toward emotional well-being. Journal of Personality and Social Psychology, 65, 45-55. https://doi.org./10.1111/1467-9280.00431

Harms, P. D., \& Luthans, F. (2012). Measuring implicit psychological constructs in organizational behaviour: An example using psychological capital. Journal of Organizational Behaviour, 33(4), 58-594. https://doi.org/10.1002/job.1785

Heled, E., Somech, A., \& Waters, L. (2016). Psychological capital as a team phenomenon: Mediating the relationship between learning climate and outcomes at the individual and team levels. The Journal of Positive Psychology, 11(3), 303-314. https://doi.org/10.1080/17439760.2015.1058971

Hodge, B., Wright, B., \& Bennett, P. (2017). Increasing students' engagement and reducing exhaustion through the provision of demanding but well-resourced training. Journal of Further and Higher Education. https://doi.org/10.1080/0309877X.2017.1363385

Hobfoll, S. E. (2011). Conservation of resource caravans and engaged settings. Journal of Occupational and Organizational Psychology, 84, 116-122. https://doi.org/10.1111/j.2044-8325.2010.02016.x

Hobfoll, S. E., Halbesleben, J., Neveu, J., \& Westman, M. (2018). Conservation of resources in the organizational context: The reality of resources and their consequences. The Annual Review of Organizational Psychology and Organizational Behaviour, 5, 10.1-10.26. https://doi.org/10.1146/annurev-orgpsych-032117-104640

Lupsa, D., Virga, D., Maricutoiu, L. P., \& Rusu, A. (2019). Increasing psychological capital: A pre-registered meta-analysis of controlled interventions. Applied Psychology: An International Review, 1-51. https://doi.org/10.1111/apps.12219

Luthans, F., Avey, J. B., Avolio, B. J., \& Peterson, S. (2010). The development and resulting performance impact of positive psychological capital. Human Resources Development Quarterly, 21, 41-66. https://doi.org/10.1002/hrdq.200034

Luthans, F., Avey, J. B., \& Patera, j. L. (2008). Experimental analysis of a web-based training 
intervention to develop positive psychological capital. Academy of Management Learning \& Education, 7(2), 209-221. https://doi.org/10.5465/AMLE.2008.32712618

Luthans, F., \& Youssef-Morgan, C. M. (2004). Human, social, and now positive psychological capital management: Investing in people for competitive advantage. Organizational Dynamics, 33(2), 143-160. https://doi.org/10.1016/j.orgdyn.2004.01.003

Martínez, I. M., Youssef-Morgan, C. M., Chambel, M. J., \& Marques-Pinto, A. (2019).

Antecedents of academic performance of university students: Academic engagement and psychological capital resources. Educational Psychology, 39(8), 1047-1067. https://doi.org/10.1080/01443410.2019.1623382

Ortega-Maldonado, A., \& Salanova, M. (2018). Psychological capital and performance among undergraduate students: the role of meaning-focused coping and satisfaction. Teaching in Higher Education, 23(3), 390-402. https://doi.org/10.1080/13562517.2017.1391199

Ozturk, A., \& Karatepe, O. M. (2019). Frontline hotel employees' psychological capital, trust in organization, and their effects on nonattendance intentions, absenteeism, and creative performance. Journal of Hospitality Marketing \& Management, 28(2), 217-239. https://doi.org/10.1080/19368623.2018.1509250

Russel, J. A. (1980). A circumplex model of affect. Journal of Personality and Social Psychology, 39(6), 1161-1178. https://doi.org/10.1037/h0077714

Salmela-Aro, K., \& Upadyaya, K. (2014). School burnout and engagement in the context of demands-resources model. British Journal of Educational Psychology, 84, 137-151. https://doi.org/10.1111/bjep.12018

Schaufeli, W. B., Martínez, I. M., Marques-Pinto, A., Salanova, M., \& Bakker, A. (2002). Burnout and engagement in university students: A cross-national study. Journal of Cross-Cultural Psychology, 33(5), 464-481. https://doi.org/10.1177/0013164405282471

Seligman, M. E. P., \& Csikszentmihalyi, M. (2000). Positive psychology: An introduction. American Psychologist, 55, 5-14. https://doi.org/10.1037/0003-066X.55.1.5 
Seligman, M. E. P., Ernst, R. M., Gillham, J., Reivich, K., \& Linkins, M. (2009). Positive education: Positive psychology and classroom interventions. Oxford Review of Education, 35(3), 293-311. https://doi.org/10.1080/03054980902934563

Selvaraj, P. R., \& Bhat, C. S. (2018). Predicting the mental health of college students with psychological capital. Journal of Mental Health, 27(3), 279-287. https://doi.org/10.1080/09638237.2018.1469738

Upadyaya, K., \& Salmela-Aro, K. (2013). Development of school engagement in association with academic success and well-being in varying social contexts: A review of empirical research. European Psychologist, 18(2), 136-147. https://doi.org/10.1027/1016-9040/a000143

Warr. P. (1987). Work, unemployment, and mental health. Oxford, England: Oxford University Press.

Warr, P. (1990). The measurement of well-being and other aspects of mental health. Journal of Occupational Psychology, 63, 193-210. https://doi.org/10.1111/j2044-8325.1990.tb00521.x

Westman, M. (2001). Stress and strain crossover. Human Relations, 54(6), 717-751. https://doi.org/10.1177/0018726701546002

Westman, M., Etzion, D., \& Chen, S. (2009). The crossover of positive experiences from business traveller to their spouses. Journal of Managerial Psychology, 24, 269-284. https://doi.org/10.1108/02683940910939340

Westman, M., Shadach, E., \& Keinan, G. (2013). The crossover of positive and negative emotions: The role of state empathy. International Journal of Stress Management, 20(2), 116-133. https://doi.org/10.1037/a0033205 